Universidade de São Paulo

Museu de Arqueologia e Etnologia

Comissão de Pós-Graduação

\title{
POLÍTICAS MUNICIPAIS DE GESTÃO DO PATRIMÔNIO ARQUEOLÓGICO
}

Plácido Cali

Tese apresentada ao Programa de Pós-Graduação do Museu de Arqueologia e Etnologia da Universidade de São Paulo, para obtenção do título de Doutor em Arqueologia

Orientador: Prof ${ }^{\circ}$ Dr. Pedro Paulo A. Funari

SÃo PaUlo

2005 


\section{Agradecimentos}

É quase impossível fazer justiça a todos os colaboradores deste projeto, que, por cinco anos, abrangeu dezenas de municípios e órgãos estaduais e federais, em diferentes esferas do poder. De qualquer forma, destaco meus sinceros agradecimentos para:

- Prof. Dr. Pedro Paulo A. Funari, pela orientação e apoio sempre presentes;

- Fundação de Amparo à Pesquisa do Estado de São Paulo - FAPESP, pelo financiamento do projeto;

- $11^{\text {a }}$ Superintendência Regional do IPHAN, por viabilizar acesso aos processos de Arqueologia do estado de Santa Catarina;

- Instituto Estadual do Patrimônio Histórico e Artístico de Minas Gerais - IEPHA;

- Supremo Tribunal Federal, em especial à Seção de Jurisprudência;

- Superior Tribunal de Justiça e Tribunais de Justiça Estaduais;

- Ministério Público Estadual (vários estados). Em especial aos Centros de Apoio Operacionais de Defesa do Meio Ambiente;

- Secretaria Municipal da Cultura, em especial à Secretária Maria Sônia Ferreira Dias; Fundação Arte e Cultura de Ilhabela e Instituto Histórico e Arqueológico de Ilhabela, pelo apoio e acolhimento ao desenvolvimento do Projeto Arqueológico de Ilhabela e ao desenvolvimento da Política de Preservação do Município;

- Parque Estadual de Ilhabela, em especial à Diretora Arq. Marília Brito, à exDiretora Arq. Kátia Regina, ao Técnico Marcos Aurélio e toda equipe;

- Ao Jornal da Ilha e todos amigos e colaboradores individuais do município de Ilhabela;

- Departamento de Cultura e Turismo do município de Peruíbe, em especial à historiadora Fátima Cristina Pires e à Turismóloga Juanita Trigo Nasser;

- Prof. Dr. José Luiz de Morais e à Profa. Dra. Maria Cristina Bruno, pelos conselhos construtivos dados na Banca de Qualificação;

- Todos os técnicos e agentes municipais das dezenas de cidades pesquisadas;

- Minha esposa Maria Luísa Moreira, pelo companheirismo e colaboração nesse trabalho. 


\section{RESUMO}

A presente Tese investiga as Políticas Municipais de Gestão do Patrimônio Arqueológico a partir do estudo de caso de dezenas de cidades em vários estados, com suas ações na área, leis e estrutura. Procura, ainda, saber como o patrimônio arqueológico está inserido nas políticas culturais locais e compara as ações de proteção dos sítios arqueológicos com as ações nos demais Bens patrimoniais.

Apresenta um estudo jurídico do papel dos entes federativos na proteção do patrimônio arqueológico e cultural, em especial o papel dos municípios, observando o que é estabelecido na Constituição Federal e a jurisprudência de vários processos julgados em várias instâncias do Judiciário.

Finalmente, propõe alguns caminhos aos municípios interessados em desenvolver políticas de gestão do patrimônio arqueológico e cultural e disponibiliza material documental de referência nunca antes sistematizado. 


\begin{abstract}
For this Thesis, based on case studies, the municipal policies for the archeological heritage management are investigated considering actions, legislation and structure of dozens of cities, in different States. The role of the archeological heritage is also investigated, in local cultural policies, and the protection of archeological sites is compared to the protection of other properties.
\end{abstract}

On a legal point of view, the role of federal entities, protecting the archeological and cultural heritage, is studied, specially the role of municipalities, considering what the Federal Constitution establishes and the jurisprudence of different lawsuits adjudicated in the various levels of the Judiciary.

This Thesis proposes some solutions for the municipalities aiming the development of cultural and archeological heritage management policies and provides reference material never before systematized. 


\section{SUMÁRIO}

Parte I - Uma abordagem crítica ao Patrimônio

1.1 - Introdução___ 08

1.2 - Os desafios da preservação ___ 13

1.3 - As perspectivas adotadas __ 17

\section{Parte II - Estudos Jurídicos}

2.1 o papel dos municípios e sua competência 22

2.2 O município na proteção do patrimônio arqueológico 28

2.3 Instâncias judiciais e estudos de casos

a) Supremo Tribunal Federal 33

b) Tribunais de Justiça e Superior Tribunal de Justiça 41

c) Tribunais Regionais Federais 45

2.4 O papel dos Estados 50

2.5 O papel da União 63

Parte III - Ações e Projetos de Municípios na Gestão do Patrimônio 69

Parte IV - Análise das Políticas Municipais Estudadas 116

Parte V - Considerações Finais 129

Parte VI - Documentação Textual Pesquisada 137 


\section{APRESENTAÇÃO}

A idéia de se investigar as políticas de gestão do patrimônio arqueológico e sugerir caminhos para seu estabelecimento surgiu durante a atuação em órgão de patrimônio municipal, seguida da experiência no órgão federal de patrimônio, ainda que temporária.

A vida acadêmica, com participação na participação em projetos do MAE/USP, a docência na cadeira de Arqueologia em universidade particular e, finalmente, a atuação junto à empresa na área de Arqueologia, suscitaram muitas reflexões sobre o potencial e limites da atuação do Poder Público Municipal na proteção e promoção do patrimônio arqueológico e cultural geral.

Os questionamentos maiores referiam-se à forma mais adequada de se organizar o patrimônio local, em termos de gestão do Poder Público Municipal; como assegurar a proteção dos bens patrimoniais, em especial os sítios; quais os limites de atuação do município e como as políticas de preservação poderiam estar organizadas para resistirem às mudanças administrativas.

Logo se formava a idéia de se estabelecer um quadro, ainda que por amostragem, da atuação dos municípios na área, conhecer suas leis e sugerir caminhos.

O projeto tomou uma envergadura maior do que a imaginada, inicialmente pela quantidade de municípios abrangidos e, principalmente, pelas implicações jurídicas na matéria. Logo, vi-me envolvido pelo Direito Constitucional, Ambiental, Administrativo e outros que, sem o devido entendimento, inviabilizaria alcançar boa parte dos objetivos propostos.

O resultado foi a pesquisa de 45 municípios, 157 leis municipais, ações e análise da estrutura, abrangendo 08 estados; análise de cerca de 50 processos no Supremo Tribunal Federal, Superior Tribunal de Justiça, Tribunais 
Regionais Federais e Tribunais Estaduais, além de 17 leis estaduais e várias leis federais. A pesquisa resultou menos propositiva e mais analítica.

Espero que esta Tese sirva de material de referência para outras pesquisas e para os municípios interessados no desenvolvimento de políticas de gestão do patrimônio. 
PARTE I

\section{UMA ABORDAGEM CRÍTICA AO PATRIMÔNIO}




\section{1 - INTRODUÇÃO}

As políticas de preservação do patrimônio arqueológico no Brasil basicamente estiveram restritas a ações governamentais. A comunidade científica priorizou a pesquisa desde o antigo Programa Nacional de Pesquisas Arqueológicas PRONAPA (1965 - 1971), sem significativas preocupações com os sítios destruídos através de escavações arqueológicas ou no processo de urbanização do país, que requeriam amplo inventário para sua proteção ${ }^{1}$.

O humanista Paulo Duarte, ao retornar do exílio, onde permaneceu por sua oposição ao Estado Novo, propôs duas importantes medidas: "o desenvolvimento de instituições arqueológicas acadêmicas e a proteção ao patrimônio" (FUNARI, 1998: 16). A instituição criada em São Paulo foi o Instituto de Pré-História, vinculado à Universidade de São Paulo, dando-Ihe um caráter científico juntamente com pesquisadores que ele ajudou a trazer ao Brasil. Já a proteção, conseguiu desempenhando importante papel na promulgação de uma legislação preservacionista do patrimônio arqueológico (DE BLASIS, 1991: 167).

Não por acaso, Paulo Duarte focalizou sua atenção e esforços sobre os sambaquis (BLASIS, 1991: 165), porque os fascinava enquanto objeto de estudo, mas também por preocupar-se com a sua acelerada destruição, utilizados para fins comerciais.

Mas, os seus sucessores preferiram apenas o caminho da pesquisa ao da preservação. Postura esta que chega até nossos dias, apenas recentemente sendo alterada. Afinal, mesmo a escavação sistemática é uma forma de destruição. Alain Ferdière (1980), em seu artigo La Fouille pour quoi faire?, já questionou os fundamentos e motivações do arqueólogo para a escavação, atividade destrutiva comparada com "a imagem do livro que se arranca e

\footnotetext{
${ }^{1}$ Acrescente-se que as pesquisas do PRONAPA, além de não resultarem em preservação de parte de cada sítio para pesquisas futuras (bloco testemunho ou similar) e aproveitamento educacional do local, tornaram-se referência para justificar futuros empreendimentos naquelas localidades, pois se justificava que o Programa já havia pesquisado a região, sendo desnecessários outros estudos e levantamentos.
} 
queima as páginas com fúria a medida em que se lê - bem ou mal (...)" (FERDIÈRE, 1980: 25).

Foi na esfera governamental, não acadêmica, que a preservação do patrimônio arqueológico encontrou espaço, inserindo-se nas políticas de proteção ao patrimônio cultural ${ }^{2}$, ainda que de forma periférica.

O Serviço do Patrimônio Histórico e Artístico Nacional (Sphan), criado em 1937 pelo esforço de alguns intelectuais ligados ao movimento modernista, nasceu no bojo do processo de consolidação do Estado Nacional e procurou delinear um perfil para a "nação brasileira", restaurando e conservando bens culturais que dessem suporte à construção de uma identidade nacional.

Coube ao Instituto de Patrimônio Histórico e Artístico Nacional (Iphan), denominação atual, o papel de identificação, promoção e gerenciamento dos bens tombados e do conjunto do patrimônio cultural da União.

Desde sua criação, o seu desempenho avançou em vários âmbitos, sejam eles no campo teórico, político ou jurídico. Os conceitos de valorização e preservação dos bens, antes restritos aos considerados monumentos e obras de arte, foram ampliados e democratizados. Incorporaram o patrimônio cultural não consagrado (conjunto de vilas operárias, senzalas, coleção de ex-votos, entre outros), como também o patrimônio natural. Na área legal, o processo de criação de leis e portarias, ao longo da existência do Iphan, permitiu que na atual Constituição da República Federativa do Brasil, em seu artigo 216, viesse a se adotar uma concepção progressista de patrimônio cultural.

\footnotetext{
${ }^{2}$ Constituem patrimônio cultural brasileiro, conforme a Constituição Federal, artigo 216, "os bens de natureza material e imaterial, tomados individualmente ou em conjunto, portadores de referência à identidade, à ação, à memória dos diferentes grupos formadores da sociedade brasileira, nos quais se incluem:

I. as formas de expressão;

II. os modos de criar, fazer e viver;

III. as criações científicas, artísticas e tecnológicas;

IV. as obras, objetos, documentos, edificações e demais espaços destinados às manifestações artístico-culturais;

V. os conjuntos urbanos e sítios de valor histórico, paisagístico, artístico, arqueológico, paleontológico, ecológico e científico."
} 
Em relação aos sítios arqueológicos e seus componentes, o gerenciamento é de responsabilidade do Iphan. A legislação determina ser todo patrimônio arqueológico um bem da União. Portanto, essa responsabilidade incide sobre sítios arqueológicos cadastrados e a diversos acervos, provenientes de pesquisa sistemática ou não, desenvolvida por instituições públicas e privadas.

Em fins dos anos 1960, a política de preservação do patrimônio cultural foi adotada também pelos estados, quando foi criado, no caso de São Paulo, o Conselho de Defesa do Patrimônio Histórico, Arqueológico, Artístico e Turístico do Estado de São Paulo (Condephaat).

A partir de fins dos anos 1970 e início da década de 1980, foi o momento dos municípios se preocuparem em assumir suas atribuições constitucionais para a defesa do patrimônio cultural. Em algumas cidades foram criados Conselhos Municipais de Preservação para estabelecer as diretrizes de proteção do patrimônio local, e, por vezes, órgãos municipais, como Departamentos ou Diretorias específicas para coordenar as políticas municipais (quando o caso, em conjunto com os conselhos municipais) e executá-las através do reconhecimento, proteção, tombamento, valorização e divulgação do patrimônio cultural.

Algumas cidades optaram celebrar convênios com Universidades Públicas e Privadas $^{3}$ para a realização de trabalhos na área de arqueologia, principalmente em relação à pesquisa em sítios arqueológicos e à constituição de Museus Regionais, utilizando-se o acervo proveniente das escavações. Recentemente, abriu-se nova possibilidade, através de Organizações não Governamentais - OnGs e empresas especializadas na área.

O estabelecimento de convênio com Universidades era uma opção economicamente mais viável, pois dispensava a remuneração dos profissionais

\footnotetext{
${ }^{3}$ No Estado de São Paulo, coube ao Instituto de Pré-História, desde sua criação em fins de 1959 até 1989, com a fusão ao Museu de Arqueologia e Etnologia, ambos da Universidade de São Paulo. Dentre as Universidades particulares, podemos destacar o Instituto de Pesquisa em Arqueologia, da Universidade Católica de Santos, criado em 1992 e o Núcleo de Arqueologia da Universidade Brás Cubas - NAUBC (Mogi das Cruzes), criado em 1995.
} 
especializados, custeando apenas suas despesas e fornecendo mão de obra para apoio aos trabalhos. Além da vantagem econômica, contava-se com profissionais provenientes de instituições reconhecidas, como a Universidade de São Paulo. Entretanto, a diretriz das pesquisas seguia uma orientação científica e acadêmica, concentrando-se em sítios e áreas da cidade do interesse da equipe de arqueólogos ali presente. A pesquisa e a identificação dos sítios muitas vezes desvinculavam-se do planejamento urbano da cidade. Assim, o Poder Público Municipal poderia financiar um projeto de levantamento e salvamento de sítios arqueológicos em uma área da cidade que não corria qualquer risco de destruição, enquanto outras áreas, ameaçadas pelo crescimento urbano, tinham seus sítios arqueológicos destruídos.

Embora a Constituição Federal conceba o patrimônio cultural brasileiro de forma abrangente, as atuações governamentais têm privilegiado alguns setores, particularmente o patrimônio edificado, com inventários e restaurações, principalmente nos centros históricos mais conhecidos (Ouro Preto e Mariana - MG, Olinda e Recife - PE, Salvador - BA, Rio de Janeiro RJ, etc.). Geralmente edifícios de uma elite social, cuja monumentalidade é visível por todos, atingindo, assim, resultados eleitoreiros imediatos. Na maioria das vezes, a ausência de uma proposta adequada de uso do Bem restaurado e de um programa educacional voltado para o patrimônio, faz com que não se estabeleçam vínculos históricos e culturais da comunidade com aquele patrimônio.

O privilégio recebido por algumas áreas do patrimônio cultural e a falta de uma política em longo prazo é sintomático da precariedade com que a matéria vem sendo tratada por alguns setores do Poder Público.

Se considerarmos os dados oficiais do Iphan sobre os "Principais projetos executados com recursos da 'Dotação Extra" ${ }^{\text {"4 }}$, nos anos de 1995, 1996 e

\footnotetext{
${ }^{4}$ Principais projetos executados pelo Iphan, entre 1995 e 1997, com recursos próprios:

1995: Recuperação do Centro Histórico de Salvador (BA); Centro de Artes e Conservações de Ouro Preto (MG); Exposição Permanente do Museu do Homem Americano (PI); Adequação da Casa França-Brasil (RJ); Conservação do Prédio do Museu de Arte Moderna (RJ);
} 
1997, notaremos que, dentre os cerca de vinte principais projetos, apenas dois são de arqueologia. Sítios de grande importância para o país e de valor científico, mas ainda assim, não por acaso, as duas áreas arqueológicas que mais aparecem na mídia.

1996: Museu Aberto do Descobrimento (BA); Construção do Anexo do Teatro Municipal (RJ); Preservação e Valorização do Sítio Arqueológico de São Miguel das Missões (RS); Obras emergenciais no Museu Nacional (RJ); Restauro e reforma de diversos museus do Rio de Janeiro, como o Palácio Capanema, Arquivo Histórico do Itamaraty e Museu Histórico Nacional (RJ);

1997: Construção de depósito climatizado na Cinemateca Brasileira (SP); Complementação da obra do Arquivo Público Mineiro (MG); Restauro e reforma da Pinacoteca do Estado (SP); Reforma e modernização de teatros, em diversos Estados; construção de centros e espaços culturais em todo em vários estados.

Dados fornecidos pelo Iphan. 


\section{2 - Os Desafios da Preservação}

As políticas de gestão do patrimônio arqueológico na esfera municipal foram pouco estudadas, sendo, portanto, várias as questões a serem respondidas nesta tese. Assim, podemos agrupar nossos objetivos principais, conforme os tópicos abaixo:

- Conhecer a realidade da legislação e da atuação dos municípios na gestão do patrimônio cultural, em especial o patrimônio arqueológico, pois tal estudo nunca foi realizado de forma aprofundada e sistemática;

- Analisar o papel dos entes federativos na gestão desse patrimônio como subsídio ao estudo dos casos levantados, verificando a constitucionalidade das ações desses municípios, o exercício de seu papel concorrente na proteção do patrimônio e o papel suplementar em legislar sobre a matéria;

- Detectar e analisar quais políticas culturais orientaram as ações dos municípios na preservação desse patrimônio; qual o papel da Arqueologia nas políticas municipais de preservação, comparada com outras áreas, como a Arquitetura; nos exemplos de cidades estudadas, o que foi priorizado em Arqueologia (histórica ou pré-colonial);

- Apontar caminhos aos municípios, em termos de ações concretas (em relação à identificação, preservação, pesquisa e promoção), para a gestão do patrimônio cultural e arqueológico local;

- Disponibilizar material documental de referência (leis federais, estaduais e municipais e processos levantados).

Considerando-se que são relativamente poucas as cidades em que já houve algum tipo de pesquisa arqueológica, e que somente no Estado de São Paulo existe cadastrado junto ao Iphan cerca de oitocentos sítios arqueológicos e aproximadamente onze mil em todo o país, é possível afirmar que o Brasil possui um rico patrimônio arqueológico, ainda que a maioria dos sítios 
permaneça desconhecida. Mesmo aqueles sítios já identificados e cadastrados pelo Iphan e pelos respectivos órgãos estaduais e municipais de pesquisa e preservação, poucos se beneficiam de seu status, pois não há pessoal, verba e estrutura por parte destes organismos para dar a devida assistência e proteção.

O caso da preservação do patrimônio arqueológico é mais problemático que outros bens (como o arquitetônico e o ambiental), haja vista a maioria dos sítios arqueológicos estar no subsolo e visível apenas quando em processo de destruição. Mesmo na situação limite da descoberta fortuita em obras, tanto empresas, Prefeituras e até mesmo algumas Universidades não sabem como proceder e a quem pedir ajuda.

Os governos municipais que tiveram a iniciativa de criarem legislação e órgãos relativos a patrimônio histórico (a maioria priorizando o patrimônio edificado) obtiveram resultados significativos na sua proteção. Mas, esses mecanismos legais estão extremamente sujeitos às mudanças de governo, podendo a área ficar paralisada, ser transformada em reduto de cargos políticos com pessoas estranhas ao meio, ou até mesmo chegar a completa extinção dos órgãos, departamentos etc.

O estudo dessas ações é hoje relevante para ter-se um quadro da atuação dos governos municipais, seus limites, perspectivas e apontar caminhos, principalmente se considerarmos a tendência dos governos estaduais e federal, repassando cada vez mais atribuições para a esfera municipal.

É importante lembrar que o crescente número de trabalhos que necessitam de Estudos Arqueológicos em empreendimentos potencialmente lesivos ao Meio Ambiente e ao Patrimônio Cultural exige fiscalização e, pelo número reduzido de técnicos do Iphan, os profissionais da área dos municípios poderiam dar o acompanhamento necessário aos trabalhos arqueológicos.

A responsabilidade da exigência do EIA/RIMA (Estudo de Impacto Ambiental/Relatório de Impacto Ambiental) foi entregue aos órgãos estaduais 
competentes, exceção feita aos casos de expressa competência federal, da alçada do IBAMA, ou de exclusivo interesse local, a cargo do município (AB'SÁBER, Aziz Nacib \& MÜLLER-PLATEBERG, 1994: 69).

"Ao determinar a execução do estudo de impacto ambiental, o órgão estadual competente, ou o IBAMA, ou, quando couber, o Município (..."). ${ }^{5}$

A Lei Federal 6.766/79, que dispõe sobre o parcelamento do solo urbano, permite aos municípios estabelecer normas complementares sobre 0 parcelamento do solo municipal.

"Lei $\mathrm{n}^{\circ}$ 6.766, de 19 de dezembro de 1979

(...) Parágrafo único - Os Estados, o Distrito Federal e os Municípios poderão estabelecer normas complementares relativas ao parcelamento do solo municipal para adequar o previsto nesta Lei às particularidades regionais e locais."

$\mathrm{O}$ artigo $13^{\circ}$ da mesma Lei determina ao município a anuência prévia para a aprovação de loteamentos e desdobramentos nas seguintes condições:

"I. quando localizados em áreas de interesse especial, tais como as de proteção aos mananciais ou patrimônio histórico, paisagístico e arqueológico, assim definidas por legislação estadual ou federal."

A Portaria IPHAN 230/02 veio compatibilizar a preservação do Patrimônio Arqueológico com o licenciamento ambiental, revolucionando o quadro da conservação e pesquisa dos sítios arqueológicos e seu uso social e educacional, além do próprio meio profissional na Arqueologia, fenômeno que será discutido mais adiante.

${ }^{5}$ Arts. $5^{\circ}$ Parágrafo único, $6^{\circ}$, Parágrafo único, e 11 , Parágrafo $2^{\circ}$, da Resolução CONAMA $n^{\circ}$ 001/86. 
A Constituição Federal, em seu artigo 20, ao estabelecer que compete concorrentemente à União, Estados e Municípios a proteção do patrimônio cultural e determinando em seu artigo 30, parágrafo $9^{\circ}$, que compete aos Municípios "promover a proteção do patrimônio histórico-cultural local, observada a legislação e a ação fiscalizadora federal e estadual", legou aos municípios uma difícil tarefa, dispondo estes de instrumentos legais para a sua execução.

O mesmo se aplica às responsabilidades dos municípios determinadas nas seguintes leis: Lei 3924/61, que dispõe sobre os monumentos arqueológicos e pré-históricos; Lei 6938/81 sobre a Política Nacional do Meio Ambiente, que inclui a proteção ao patrimônio cultural; Lei 9605/98 que dispõe sobre as sanções penais de atividades lesivas ao meio ambiente e ao patrimônio cultural; sem mencionar as várias Cartas Patrimoniais assinadas pelo Brasil, nas quais os municípios têm papel importante na defesa do Patrimônio Cultural (CALI, 1999b). 


\section{3 - As perspectivas adotadas}

Sendo o objeto deste projeto a investigação das práticas de pesquisa e preservação do patrimônio arqueológico desenvolvidas pelos governos municipais, autonomamente ou em conjunto com instituições de pesquisa, são necessários amplos estudos a respeito dos conceitos adotados e das políticas implementadas. Para tanto, é preciso entender essa prática no contexto das três esferas de governo, no âmbito das estratégias de políticas públicas, particularmente das políticas culturais.

Norberto Bobbio (1977) distingue política cultural e política da cultura. A primeira é o planejamento da cultura feita pelos políticos, visando fins políticos. A segunda é a política da comunidade dos homens da cultura, voltada para o desenvolvimento da cultura com o acesso de todos.

Segundo FONSECA (1997: 43), na "perspectiva liberal, cabe à sociedade produzir cultura. Ao Estado, cabe apenas garantir as condições para que esse direito possa ser exercido por todos os cidadãos". Ora, isso implica numa atuação efetiva do Estado não só para defender a preservação do patrimônio, mas para criar condições da sociedade formular e implementar as políticas culturais e de preservação, a qual a realidade brasileira tem demonstrado ser bastante difícil.

Assim, acreditamos serem os governos municipais bons laboratórios para experimentação de práticas de preservação e políticas mais participativas na gestão do patrimônio histórico e arqueológico. E são os municípios que vêm implementando com maior visibilidade propostas neste sentido.

Para isso, é necessário um levantamento de exemplos de políticas municipais de preservação do patrimônio (órgãos, legislação, ações, etc.). Selecionamos cidades do Estado de São Paulo e algumas de outros estados que tenham, notadamente, atuado na gestão do patrimônio arqueológico, como exemplos para desenvolvermos um estudo comparativo dos municípios elencados, 
considerando-se linhas conceituais de formulação, contexto histórico e político, inserção orgânica no governo, atuação e obtenção de resultados.

Com base no referido estudo visaremos, primeiramente, traçar um quadro das políticas municipais de gestão do patrimônio arqueológico e histórico e, em segundo lugar, propor um programa mínimo de estratégias aos municípios interessados na preservação do patrimônio arqueológico e histórico local.

A pesquisa tem um caráter amplo, seja por permear as três esferas de governo (federal, estaduais e municipais), pela gama de conceitos envolvidos, utilizando, concomitantemente, estratégias e conceitos científicos e políticos, ora aliados, ora em conflito, seja pelas diferenças de tempo e espaço.

No âmbito teórico e conceitual, a Arqueologia Pública insere-se hoje no bojo das tendências contemporâneas da $\operatorname{Arqueologia}^{6}$ e, em especial, da Arqueologia Pós-processual.

A Arqueologia Pós-processual, encabeçada por lan Hodder, surgiu na Inglaterra nos anos 1980, mantendo pontos em comum com a Arqueologia Social, restabelecendo os seus vínculos com a História, já anteriormente retomados pela Arqueologia Social e pela Arqueologia Tradicional.

Não seria o caso de definirmos aqui todos os desdobramentos da Arqueologia Pós-processual, pela ampla gama de conceitos envolvidos. Contudo, interessanos a sua abordagem da ideologia, do social, da educação, evidenciando a relação dialética entre o passado e o presente. "Interpreta-se o passado em função do presente, mas pode também utilizar-se o passado para criticar e desafiar o presente" (Hodder, 1990: 201).

A própria definição de Arqueologia como "o estudo do poder" por Michael Shanks e Christopher Tilley (1987: 08) e como prática de construção de um

${ }^{6}$ Destaca-se, na abordagem da Arqueologia Pública, a atuação do World Archaeological Congress. 
passado por lan Hodder (1986: 16), vincula-se, diretamente, às relações de poder na sociedade como um todo (FUNARI, 1989: 204). Nesse sentido, a Arqueologia acadêmica, financiada pelo Estado e pela iniciativa privada, "opera como parte de um discurso cultural mais amplo que serve para reproduzir a relação entre dominantes e dominados" (Shanks, 1987: 189).

Nesse contexto, o patrimônio cultural não pode ser visto e assimilado enquanto monumento, conforme se referiu Walter Benjamim (1986). Para Benjamim, o monumento faz parte da memória oficial celebrativa, constituído para durar e envolto em significado. Já o documento constitui-se em um fragmento do passado, sujeito ao esquecimento ou à (re)construção do conhecimento histórico. Aproxima-se, assim, da noção de documento arqueológico, constituído pelos sítios arqueológicos e, principalmente, pela cultura material, que descartada, transforma-se em documento para o arqueólogo, quando analisada em seu contexto, sujeita à várias interpretações. Dessa forma, patrimônio cultural, no qual a arqueologia é uma das ciências que Ihe dão um corpus, é compreendido como um legado, de diferentes formas de registro, das múltiplas memórias sociais.

$\mathrm{Na}$ área da educação, a difusão e reflexão acerca do conceito de patrimônio cultural é fundamental tanto para educadores quanto para os arqueólogos, pelo papel de formadores do conhecimento e de opinião que exercem socialmente. Como lembrou MacKenzie (1990: 05), "Educação liga-se, inseparavelmente, à Arqueologia porque a Arqueologia fornece a matéria-prima para o ensino dos temas que se referem à vida social".

No caso da Arqueologia brasileira, como escreveu FUNARI (1995: 06), ela "tem sido encarada, tradicionalmente, de maneira a minimizar a cultura e presença indígenas e a maximizar a chamada missão civilizadora dos Europeus".

Esse tipo de preocupação também é abordado por Norberto L. Guarinello (1998) e resultou na publicação do primeiro manual para escolas de ensino 
fundamental sobre Arqueologia brasileira $^{7}$, adotado pelo Ministério da Educação e distribuído a centenas de escolas em todo o país.

Assim, a Arqueologia Pós-processual, nas suas várias facetas (arqueologia simbólica, contextual, estrutural, crítica, feminista, indígena, operária, etc.) favorece a investigação das políticas públicas do Estado e as relações entre arqueologia e poder, arqueologia e sociedade, arqueologia e educação, etc.

Essas abordagens, aplicadas ao estudo das políticas de gestão do patrimônio arqueológico em nível municipal, podem fornecer instrumentos para análises das motivações ideológicas e implicações sociais dessas práticas, entendidas no contexto nacional, na relação do governo com a sociedade.

${ }^{7}$ GUARINELLO, Norberto Luiz. Os primeiros habitantes do Brasil. São Paulo: Atual Editora, 1994. 


\section{PARTE II}

\section{ESTUDOS JURÍDICOS}




\title{
Parte II \\ ESTUDOS JURÍDICOS
}

Temas como a competência dos municípios na proteção do patrimônio cultural, o papel e limites dos tombamentos e inventários de Bens Culturais, competência para legislar sobre a matéria, relação entre Patrimônio Cultural e Meio Ambiente, o papel do Ministério Público e as diferentes instâncias para análise de casos têm diferentes interpretações que, muitas vezes, são resolvidas no Superior Tribunal Federal para julgar a constitucionalidade do caso.

\subsection{0 papel dos Municípios e sua competência}

Este é um dos temas mais discutidos e envolve as funções dos Conselhos Municipais de Patrimônio Cultural, o tombamento municipal, a competência em legislar ou não sobre a matéria, ações administrativas, etc.

Convém, primeiramente, definir o sentido da palavra competência, tal qual defendido por José Afonso da Silva ${ }^{8}$ :

\begin{abstract}
"Competência é a faculdade juridicamente atribuída a uma entidade, ou a um órgão ou agente do Poder Público para emitir decisões. Competências são as diversas modalidades de poder de que se servem os órgãos ou entidades estatais para realizar suas funções".
\end{abstract}

Nosso modelo federativo repartiu as competências privativas, estabelecendo àquelas pertencentes à União e aos Municípios e reservando aos Estadosmembros as restantes, ou outras competências que a União venha a Ihes delegar. Assim, cada ente federativo possui suas próprias competências. As

\footnotetext{
${ }^{8}$ SILVA , José Afonso da. Curso de Direito Constitucional Positivo São Paulo: Malheiros, 1997, p. 455.
} 
competências privativas da União estão assinaladas nos artigos 21 e 22, as municipais no artigo 30 e as estaduais no artigo $25^{9}$ da Constituição Federal.

É preciso saber, portanto, o que é atribuído aos municípios. De acordo com José Afonso da Silva, há um princípio que nos dá uma base em matéria de repartição de competência: o princípio do interesse. Através desse princípio, dividiríamos as competências conforme o interesse seja local, regional ou nacional.

O Brasil, a exemplo da Alemanha, adotou competências privativas, exclusivas, comuns, concorrentes e suplementares. ${ }^{10}$

É a mudança do federalismo clássico para o federalismo cooperativo, onde podemos encontrar as competências comuns e concorrentes. ${ }^{11}$ Assim, além da repartição horizontal de competência típica do federalismo clássico, a mudança do federalismo fez surgir a "repartição vertical de competência, que realiza a distribuição de idêntica matéria legislativa entre a União e os Estadosmembros, estabelecendo condomínio legislativo consoante regras constitucionais de convivência". ${ }^{12}$ "Trata-se do denominado federalismo cooperativo, nos quais os níveis de governo não se digladiam pelas suas

\footnotetext{
${ }^{9}$ Art. $25, \S 1^{\circ}$ São reservadas aos Estados as competências que não Ihes sejam vedadas por esta Constituição.

${ }^{10}$ Extensão das competências (ARAÚJO \& NUNES Jr., 2002: 218):

a) Exclusiva: quando é atribuída a uma entidade com exclusão das demais (art. 21 da CF);

b) Privativa: quando enumerada como própria de uma entidade, com possibilidade, no entanto, de delegação ou de competência suplementar (art. 22 e seu parágrafo único da CF);

c) Comum, cumulativa ou paralela: todos exercem conjuntamente (art. 23 da CF):

d) Concorrente: a competência é repartida, mas a Constituição traz regras próprias para sua distribuição;

e) Suplementar (MORAES, 2002: 57):"está atrelada à legislação ampla, a qual, em razão da existência de peculiaridade, necessite adaptação para aquela parcela do território nacional, sendo premissa básica dessa regulamentação sua existência para a manutenção do bem jurídico nessa parcela do território, sem a qual o objeto de proteção legal pereceria".

${ }^{11}$ CENTRO DE APOIO DE DEFESA DO MEIO AMBIENTE. A Competência dos Entes Federados na Constituição de 1988. Ministério Público do Estado do RS. Disponível na Rede Mundial de Computadores: http://www.mp.rs.gov.br/hmpage/homepage2.nsf/pages/cma mp404

${ }^{12}$ MUKAI, Toshio. Direito Ambiental Sistematizado. ED. Forense Universitária, 1998, p.16.
} 
competências, mas se unem para, cada qual, dentro de suas atribuições, darem conta das necessidades dos administrados". ${ }^{13}$

A Constituição Federal possui um sistema complexo que, segundo SILVA (1997: 455), "busca realizar o equilíbrio federativo, por meio de uma repartição de competências que se fundamenta na técnica de enumeração dos poderes da União (arts. 21 e 22), com poderes remanescentes para os Estados (art. 25, $\S 1^{\circ}$ ) e poderes definidos indicativamente para os Municípios (art. 30), mas combina, com essa reserva de campos específicos (nem sempre exclusivos, mas apenas privativos), possibilidades de delegação (art. 22, parágrafo único), áreas comuns em que prevêem atuações paralelas da União, Estados, Distrito Federal e Municípios (art. 23) e setores concorrentes entre União e Estados em que a competência para estabelecer políticas gerais, diretrizes gerais ou normas gerais cabe à União, enquanto se defere aos Estados e até aos Municípios a competência suplementar".

A competência de legislar pode ser atribuída a um ente da federação de diversas formas: exclusiva, privativa, concorrente ou suplementar. As competências exclusivas e privativas estão elencadas na Constituição. O problema recai sobre as competências concorrente e suplementar, justamente no contexto em que se enquadram os municípios para legislarem sobre a proteção do patrimônio cultural.

Depois da competência exclusiva da União, com suas normas ${ }^{14}$ gerais, "restam a Estados e Municípios o campo das regras especiais, divididas em concorrentes e suplementares. A concorrente pura é aquela cuja matéria não necessite de regra geral, pois o objeto jurídico protegido é tão especial que não existe em outras regiões. A suplementar, de forma contrária, está atrelada à legislação ampla, a qual, em razão da existência de peculiaridade, necessite adaptação para aquela parcela do território nacional, sendo premissa básica dessa regulamentação sua existência para a manutenção do bem jurídico

\footnotetext{
${ }^{13}$ Idem, p. 23.

${ }^{14}$ Norma: "É a diretriz de conduta socialmente estabelecida pelo direito positivo, i.e., o direito criado pelo Estado e, portanto, imposto". ACQUAVIVA, M. C. Dicionário Jurídico Brasileiro Acquaviva. São Paulo: Ed. Jurídica Brasileira, 1993, p. 1285.
} 
nessa parcela do território, sem a qual o objeto de proteção legal pereceria" (MORAES, 2002: 56 - 57).

Mas em matéria de competência a Constituição Federal não trata exclusivamente da natureza legislativa. Ela coloca também hipóteses de competência material ou administrativa. Trata-se da atribuição ao Poder Público do "poder-dever de realizações de índole político-administrativa, e não a capacidade legiferante" (ARAÚJO \& NUNES Jr., 2002: 214).

Além da repartição horizontal das competências entre os entes federativos, pela qual somente quem recebeu aquela atribuição pode exercê-la, há também o critério denominado vertical, no qual a Constituição Federal atribui o trato da mesma matéria a mais de um ente federativo. Nesses casos, é especificado o nível de intervenção de cada ente (competências concorrentes próprias) ou se admite que todos os entes exerçam indistintamente a mesma competência (competências comuns e competências concorrentes impróprias).

Dentre as competências materiais compartilhadas pelos entes federativos (chamadas de competências comuns, cumulativas ou paralelas), previstas no artigo 23 da Constituição Federal, encontram-se os seguintes incisos:

III - proteger os documentos, as obras e outros bens de valor histórico, artístico e cultural, os monumentos, as paisagens naturais notáveis e os sítios arqueológicos; IV - impedir a evasão, a destruição e a descaracterização de obras de arte e de outros bens de valor histórico, artístico ou cultural;

Continuando dentro do critério vertical de distribuição de competências, há aquelas concorrentes, competência legislativa simultânea a mais de um dos entes federativos. Estas são classificadas como próprias e impróprias. As primeiras não estão expressas na Constituição, mas se aplicam quando há a necessidade de amparo legal para o exercício de uma competência comum, como por exemplo, o $\S 6$ do art. 23 da Constituição: "proteger o meio ambiente 
e combater a poluição em qualquer de suas formas". Já as competências concorrentes próprias estão assinaladas no art. 24 , §§ $1^{\circ}$ e $2^{\circ}$ da Constituição. Logo, a União elabora a norma geral e o Estado-membro a especial, exercendo a competência chamada suplementar.

Em suma, as competências concorrentes próprias ocorrem em três níveis, como nos lembra ARAÚJO \& NUNES Jr. (2002: 216): "no federal, onde foi conferido à União o poder de edição de normas gerais ${ }^{15}$; no estadual, em que foi outorgada competência suplementar aos Estados-membros; e no municipal, onde os Municípios ficaram encarregados da suplementação das normas gerais e estaduais em nível local todas as vezes em que este interesse ficar evidenciado".

Dentre as competências concorrentes próprias disciplinadas no art. 24 da Carta Magna, encontramos o § 7: "proteção ao patrimônio histórico, cultural, artístico, turístico e paisagístico"; e o § 9: "responsabilidade por dano ao meio ambiente, ao consumidor, a bens de direitos de valor artístico, estético, histórico, turístico e paisagístico".

De volta aos municípios, suas competências legislativas se baseiam no interesse local (art. 30, § 1) e na necessidade de suplementação da legislação federal e estadual.

Quanto às competências materiais, encontram-se no art. 23 da Constituição e no artigo 30, e destacamos o § 9: "promover a proteção do patrimônio históricocultural local, observada a legislação e a ação fiscalizadora federal e estadual".

15 "Normas gerais são todas as normas emanadas da União, desde que aplicáveis uniformemente a todos os Estados e a todos os cidadãos, sem discriminações, ou seja normas de aplicação isonômica em todo o território nacional. Tais normas podem dispor apenas sobre princípios ou descer a detalhes de regulamentação, desde que uniformes em todo o País, de acordo com a maior ou menor intervenção que a União queira exercer nessas matérias, deixando aos Estados maior ou menor autonomia" (GRECO, Leonardo. Competências Constitucionais em Matéria Ambiental. São Paulo: Revista dos Tribunais, vol. 687, jan. 1993). 
Para Jacson Corrêa ${ }^{16}$, "normas sobre o corte e poda de árvores ou preservação de seu patrimônio histórico, cultural e paisagístico representam, na sua essência, interesses que estão localizados dentro da urbe, portanto, não admitem a ingerência dos demais entes federados".

Resumindo a matéria relativa ao Patrimônio Cultural, o município tem competência comum (art. $23 \S 3^{17}$ ) com os demais entes federativos e competência exclusiva (art. 30), que no caso do $\S 9^{18}$ é material e nos $\S \S 1$ e 2 19 são legislativas. Este último $\S 2$ implica na competência de caráter suplementar.

${ }^{16}$ CORREAA, Jacson. A preservação do meio ambiente e o conflito de competências legislativas. $O$ interesse local e a atividade mineraria. Santa Catarina: Ministério Público de Santa Catarina. Disponível na Rede Mundial de Computadores: http://www.mp.sc.gov.br/internet/centros/doutrina/cme/jacsoncorrea presmeioamb.htm

17 "III - proteger os documentos, as obras e outros bens de valor histórico, artístico e cultural, os monumentos, as paisagens naturais notáveis e os sítios arqueológicos".

18 "IX - promover a proteção do patrimônio histórico - cultural local, observada a legislação e a ação fiscalizadora federal e estadual".

19 "I - legislar sobre assuntos de interesse local.

II - suplementar a legislação federal e estadual no que couber". 


\title{
2.2 O Município na Proteção do Patrimônio Arqueológico
}

\author{
Competência Legislativa
}

No caso do patrimônio arqueológico, sendo um Bem já protegido pela Constituição Federal, pela Lei Federal 3924/61, além da Lei $9605 / 98^{20}$, compete ao município em termos legais, atuar em caráter suplementar.

A competência suplementar tem como pressuposto:

"A capacidade suplementária está condicionada à necessidade de aperfeiçoar a legislação federal ou diante da constatação de lacunas ou de imperfeições da norma geral federal. (...) Ressalte-se que não se pode suplementar um texto legal para descumpri-lo ou para deturpar sua intenção, isto é, para desviar-se da mens legis ambiental federal." ${ }^{21}$

O Tribunal de Justiça de Minas Gerais já analisou vários casos sobre a constitucionalidade do município legislar sobre seu patrimônio cultural e meio ambiente, manifestando-se favoravelmente.

\section{"MEIO AMBIENTE - LEGISLAÇÃO MUNICIPAL - COMPETÊNCIA - INFRINGÊNCIA - AUTUAÇÃO - LEGALIDADE - Possui o município competência para legislar sobre matéria ambiental, para atender interesses}

\footnotetext{
${ }^{20}$ A Lei 9605/98, em sua Seção IV, Dos Crimes Contra o Ordenamento Urbano e o Patrimônio Cultural, considera crime alterar o aspecto ou estrutura de edificação ou local especialmente protegido por lei, ato administrativo ou decisão judicial, em razão de seu valor arqueológico, entre outros, sem autorização da autoridade competente ou em desacordo com a concedida, e indicando como pena a reclusão, de um a três anos, e multa (art. 63). Já o artigo 64 é específico com relação à construção em solo não edificável, ou no seu entorno, assim considerado em razão de seu valor arqueológico, entre outros, sem autorização da autoridade competente ou em desacordo com a concedida. A pena para esse crime é detenção, de seis meses a um ano, e multa.

${ }^{21}$ MACHADO, Paulo Affonso Leme. Direito Ambiental Brasileiro. ED. Malheiros, 1998, p. 48.
} 
locais, motivo por que é válida a autuação de empresa pela municipalidade, através de auto regularmente lavrado, em razão de infringência de dispositivos de lei municipal que cuida daquela matéria."

(TJMG, Apelação Cível no 190.450-7/00, Comarca de Manhuaçu, apelante: Parmalat - Indústria e Comércio de Laticínios Ltda, apelado: Município de Manhuaçu, rel. Des.

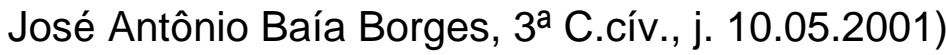

"EMBARGOS À EXECUÇÃO - COMPETÊNCIA MUNICIPAL PARA LEGISLAR SOBRE PROTEÇÃO AO MEIO AMBIENTE. Com arrimo na Constituição Federal, arts. 23, VI, e 30, I e II, é o competente o município para legislar sobre proteção do meio ambiente, nos limites de sua territoriedade, para atender situações de interesse local."

(TJMG, embargos infringentes $n^{\circ} 000.138 .453-6 / 01$ na apelação cível n000.138.453-6/00, Comarca de Belo Horizonte, rel. Des. Corrêa de Marins, j. 21.10.1999)

"COMPETÊNCIA - MUNICÍPIOS - LEGISLAÇÃO QUESTÕES - MEIO AMBIENTE - POSSIBILIDADE COMPETÊNCIA SUPLEMENTAR - POLÍTICA LOCAL PROTEÇÃO MEIO AMBIENTE - NORMAS - INTERESSE SOCIAL - Aos Municípios caberá legislar sobre as questões ambientais, em caráter suplementar, complementando a legislação federal, de caráter geral, naquilo que couber, em razão da competência comum, constitucionalmente prevista, para a execução de planejamento de políticas de proteção ambiental, de que decorre a necessidade de baixar normas visando a este fim, por estar a matéria relativa ao meio ambiente inarredavelmente ligada ao interesse social." 
(TJMG, Apelação Cível n¹25.185/9, Comarca de Belo Horizonte, rel. Des. Reynaldo Ximenes Carneiro, j. 20.08.1998)

"CONSTITUCIONAL - PROTEÇÃO DO MEIO AMBIENTE

- COMPETÊNCIA DO MUNICÍPIO PARA LEGISLAR, SUPLETIVAMENTE, SOBRE A MATÉRIA, ATENDENDO ÀS PECULIARIDADES LOCAIS, SEM CONTRARIAR A LEGISLAÇÃO FEDERAL E ESTADUAL DE REGÊNCIA MS DENEGADO - APELO DESPROVIDO".

(TJMG, Apelação Cível nº 000.181.241-1/00, Comarca de Guarani, rel. Des. Aloysio Nogueira, $3^{a}$ C.cív., j.14.12.2000)

\section{Competência Material}

A competência material é bastante ampla, abrangendo um conjunto de ações do Poder Público Municipal visando proteger o patrimônio arqueológico e cultural local. Embora o art. 30 da CF refira-se apenas a "proteção", o termo deve ser entendido de maneira abrangente, de forma a contemplar ações preventivas que indiretamente resultem também na sua proteção. Daí o artigo 216, § 1, tratar também de formas de acautelamento realizadas pelo Poder Público, como inventários, registros, etc.

\footnotetext{
§ $1 .^{\circ}$ O poder público, com a colaboração da comunidade, promoverá e protegerá o patrimônio cultural brasileiro, por meio de inventários, registros, vigilância, tombamento e desapropriação, e de outras formas de acautelamento e preservação.
}

Trata-se de competência comum dos entes federativos, parte do "poder-dever" do Poder Público, mas que, infelizmente, é pouco exercido. O seu cumprimento implica na identificação, proteção e promoção do patrimônio local. 
O patrimônio arqueológico e cultural, assim como o ambiental, deve ser regido pelo princípio da prevenção, devendo o Poder Público atuar de forma acautelatória, antes de reparatória. Conforme assinalou Vânia Maria Tuglio, há divergências entre autores sobre à nomenclatura dada ao princípio, sendo que, além do termo "prevenção", alguns preferem "precaução". Édis Milaré ${ }^{22}$ opta pela expressão princípio da prevenção, "como fórmula simplificadora, uma vez que prevenção, pelo seu caráter genérico, engloba precaução, de caráter possivelmente específico".

A competência material dos municípios é mais fácil de ser percebida, pois derivam de ações concretas de ordem político-administrativas.

A competência legislativa dos municípios é um tema ainda não pacífico entre os doutrinadores jurídicos e mesmo na produção jurisprudencial. Porém, o que se observa no levantamento dos julgados é que, apesar das decisões dos juízes singulares variarem em relação à competência dos municípios de legislarem sobre patrimônio cultural, os Tribunais Superiores e o Supremo Tribunal Federal estão, reiteradamente, favoráveis a essa competência legislativa, desde que se respeite o conteúdo das legislações federal e estadual.

Com o advento do Estatuto da Cidade, Lei 10.257/01, que estabelece as diretrizes gerais da política urbana, a proteção do patrimônio arqueológico e cultural foi contemplado em cinco artigos. No artigo $2^{\circ}$, que trata das funções sociais e da propriedade urbana, coloca como diretriz a proteção, preservação e recuperação do patrimônio cultural e arqueológico.

Art. $2^{\circ}$ A política urbana tem por objetivo ordenar o pleno desenvolvimento das funções sociais da cidade e da propriedade urbana, mediante as seguintes diretrizes gerais: $(\ldots)$

\footnotetext{
${ }^{22}$ MILARÉ, Édis. Direito do Ambiente. Revista dos Tribunais, 2.001, p. 117-118.
} 
XII - proteção, preservação e recuperação do meio ambiente natural e construído, do patrimônio cultural, histórico, artístico, paisagístico e arqueológico;

No artigo $4^{\circ}$ está previsto o "tombamento de imóveis ou de mobiliário urbano". Já no artigo $37^{\circ}$ ao estabelecer os critérios de análise de empreendimentos urbanos para fins do Estudo Prévio de Impacto de Vizinhança (EIV), considera no inciso VII a "paisagem urbana e patrimônio natural e cultural".

No artigo $26^{\circ}$, que trata do direito de preempção ${ }^{23}$, estabelece esse direito ao poder público, no caso de áreas de interesse histórico, cultural e paisagístico. $E$, finalmente, no artigo 35, que trata da transferência do direito de construir, possibilita autorizar o proprietário de imóvel urbano a construir em outro local, quando seu imóvel for considerado necessário para fins de preservação, se de interesse histórico, ambiental, paisagístico, social ou cultural (§ II).

${ }^{23}$ Direito de Preempção: confere ao Poder Público preferência para aquisição de imóvel urbano objeto de alienação onerosa entre particulares 


\subsection{Instâncias Judiciais e Estudos de casos}

a) Supremo Tribunal Federal

O STF é um órgão de cúpula do Judiciário composto por 11 ministros. Dentre suas funções, cabe-Ihe, principalmente, a guarda da Constituição Federal. Mas como explica José Afonso da Silva ${ }^{24}$, este não é o único órgão com atribuição de conhecer e declarar inconstitucionalidades, visto que qualquer juiz pode declará-las no estudo de caso.

Entre as várias funções, estabelecidas no Artigo 102 da CF 1988, interessa-nos mais especificamente aquelas que resultam no julgamento de temas que podem ser originados em processos ligados à proteção de Bens Culturais ou Ambientais diretamente, ou indiretamente, como no caso de competência dos entes federativos.

Art. 102. Compete ao Supremo Tribunal Federal, precipuamente, a guarda da Constituição, cabendo-Ihe:

I - processar e julgar, originariamente:

a) a ação direta de inconstitucionalidade de lei ou ato normativo federal ou estadual;

(...)

f) as causas e os conflitos entre a União e os Estados, a União e o Distrito Federal, ou entre uns e outros, inclusive as respectivas entidades da administração indireta;

(...)

III - julgar, mediante recurso extraordinário, as causas decididas em única ou última instância, quando a decisão recorrida:

a) contrariar dispositivo desta Constituição;

b) declarar a inconstitucionalidade de tratado ou lei federal;

c) julgar válida lei ou ato de governo local contestado em face desta Constituição.

${ }^{24}$ SILVA, José Afonso da. Curso de Direito Constitucional Positivo. São Paulo: Malheiros Editores, 2001, p. 558. 
Os casos do Supremo Tribunal Federal que analisamos se referem, direta ou indiretamente, sobre a competência dos entes federativos no que diz respeito ao patrimônio cultural.

Sobre os municípios e os estados discute-se a constitucionalidade das leis de tombamento, frequentemente contestadas por particulares, mas que o STF tem demonstrado e assegurado o direito desses entes de proteger o patrimônio cultural local e a competência suplementar dos municípios para legislar sobre a matéria.

Sobre isso, citaremos alguns exemplos, como o Recurso Extraordinário ${ }^{25}$ ajuizado por Marcy D. Ibrahim e outros requerendo a anulação do tombamento de sua propriedade pela lei municipal de Juiz de Fora (MG), alegando ofensa à Constituição Federal, nos artigos 5, XXII (direito de propriedade), 24, VII (competência concorrente da União, Estados e Distrito Federal sobre proteção ao patrimônio público, cultural, artístico, turístico e paisagístico) e $216 \S 1^{\circ}$. O Juiz da Comarca de Juiz de Fora se manifestou favorável aos proprietários, julgando procedente a ação.

Houve o reexame necessário e o Tribunal de Justiça de Minas Gerais decidiu pela constitucionalidade de lei municipal que dispõe sobre tombamento, na proteção de seu patrimônio cultural, limitando-se a estabelecer as formas de tal proteção, o órgão competente e os procedimentos necessários. Dessa forma, Ibrahim entrou com Recurso Extraordinário, sustentando que o acórdão do Tribunal de Justiça de MG feriu o dispositivo constitucional que estabelece regra clara de competência para legislar sobre proteção ao patrimônio histórico-cultural. Houve parecer da Procuradoria Geral da República e depois o parecer do relator Min. Carlos Velloso sobre o aceitamento ou não do recurso. Os pareceres negaram o recurso do proprietário, mantendo-se favorável ao município.

\footnotetext{
${ }^{25}$ Recurso Extraordinário 308399/MG. Relator Min.Carlos Velloso. Data: 14/04/2005. Julgado em 29/03/2005.
} 
Destaca-se no parecer do Min. Carlos Velloso a fundamentação que ressalva a competência dos municípios para legislar sobre assuntos de interesse local, conforme a Constituição Federal (art. 30, I) e, no que couber, suplementar a legislação federal e estadual (art. 30, II) no que diz respeito ao interesse local.

Outro exemplo é a contestação, em Curitiba - PR, sobre Prédio considerado Unidade de Interesse de Preservação, por decreto do Prefeito Municipal de Curitiba, cujos proprietários entraram com mandado de segurança contra o ato da Prefeitura, que Ihes negou autorização para demolir tal imóvel. Como resultado, o Recurso foi negado por unanimidade de votos, justificando-se não haver violação a direito adquirido ou a direito de propriedade. ${ }^{26}$

Também no Paraná, no mesmo ano de 1988, há uma ação proposta contra o Estado do Paraná, visando à declaração de nulidade de ato de tombamento, feito pelo Estado, e que teve por objeto imóvel de propriedade dos autores. A declaração de nulidade é pedida com fundamento em dupla motivação: por ser nulo o processo administrativo em que se constituiu o ato de tombamento; pela insubsistência em si desse ato, por não preencher o imóvel os requisitos de valor artístico ou histórico que lhe justifiquem o tombamento. A decisão de primeiro grau se ateve às nulidades do processo administrativo, para julgar procedente a ação. O relator da Egrégia Terceira Câmara Cível do Tribunal de Justiça do Paraná rejeitou as argüidas nulidades do processo administrativo. Teve por válida a notificação feita aos autores, de que se achava instaurado o processo de tombamento e por desnecessária a notificação pessoal da esposa de cada autor. A maioria deu provimento parcial à apelação do Estado e dos proprietários do imóvel, bem como o reexame necessário, para determinar que, afastada a preliminar de nulidade do processo administrativo, retornem os autos ao Juízo de origem a fim de ser julgada a ação no concernente ao mérito do tombamento. Irresignados, os proprietários do imóvel protocolaram agravo regimental sustentando que ocorrera o prequestionamento dos dispositivos constitucionais e legais. Como resultado, o relator da Segunda Turma do

\footnotetext{
26 Número do processo: Recurso extraordinário no 114.468 - 8 Paraná. Relator: CARLOS MADEIRA. Data do acórdão: 31/05/1988. Data da publicação: 24/06/1988
} 
Supremo Tribunal Federal, por decisão unânime, negou provimento ao Agravo Regimental. $^{27}$

No Estado do Rio de Janeiro há um caso que passou por várias instâncias judiciárias, da Comarca até o STF. Pelos decretos municipais $\mathrm{n}^{0} 1.459$, de 08.12.1975 e 1.520, de 23.04.1976, foram declarados de utilidade pública para fins de desapropriação o prédio da Fazenda São Bernardino, tombado pelo Patrimônio Histórico e Artístico Nacional, e uma área de $1.327 .175 \mathrm{~m}^{2}$, destinada à implantação do "Parque Metropolitano de Múltiplo uso de São Bernardino", cujo projeto logrou aprovação do Governo Estadual para execução no período 1976/1977, mediante convênio que seria celebrado com a Fundação para o Desenvolvimento da Região Metropolitana do Rio de Janeiro (Fundrem). Ajuizada a desapropriação, o Município de Nova Iguaçu se imitiu na posse do imóvel desde $1^{\circ}$ outubro de 1976, não pagando a indenização devida ou atendida a finalidade do ato expropriatório. O convênio também não foi celebrado. A Prefeitura revogou o ato expropriatório pelo Município de Nova Iguaçu. O Juízo de $1^{\circ}$ grau decidiu: “(..) julgo a ação procedente em parte para condenar: a) a Prefeitura de Nova Iguaçu a entregar, de imediato, os bens descritos na inicial do Autor, em face da revogação dos atos expropriatórios e conseqüente perda de objeto da retrocessão, responder por perdas e danos, a partir da data da imissão na posse $\left(1^{\circ} .10 .1976\right)$ até a efetiva entrega, além de restaurar, em conjunto com a União Federal (esta em solidariedade com a litisconsorte Pró-Memória) o acervo arquitetônico tombado, na proporção dos danos pela mesma causados (ou seja, pela deterioração do patrimônio do estado em que já se encontrava àquela data e pelo tempo em que o detiver); b) a União Federal e sua litisconsorte, como assinalado no item anterior e no restante da obrigação de restaurar o mencionado conjunto; (...)". Da sentença apelaram todos os que participaram da ação. Insurgiu-se o espólio autor contra a condenação do Município à restauração da sede da Fazenda, afirmando que tal ônus deveria ser suportado pela União apenas. O Município de Nova Iguaçu alegou que se a ação era de retrocessão e houvera desistência da desapropriação, ficara o pedido prejudicado, devendo ser a ação referida

\footnotetext{
${ }^{27}$ Número do processo: Agravo de instrumento (regimental) no 109.798-1 Paraná. Relator: FRANCISCO REZEK. Data do acórdão: 26/02/1988. Data da publicação: 25/03/1988
} 
julgada extinta. A União atacou a sentença na parte em que a responsabilizou pelos danos sofridos pelo imóvel, ponto de vista que foi também sustentado pela Fundação Pró-Memória. Nesse Tribunal, manteve-se, por maioria, a decisão de primeiro grau, ficando vencido o Ministro Ilmar Galvão. Este deu provimento à apelação da União e da Fundação Pró-Memória, em face do ensinamento de Hely Lopes Meirelles ${ }^{28}$, segundo o qual: "O tombamento, em princípio, não obriga a indenização, salvo se as condições impostas para a conservação do bem acarretam despesas extraordinárias para o proprietário, ou resultam da interdição do uso do mesmo bem, ou prejudicam a sua normal utilização, suprimindo ou depreciando o seu valor econômico". O relator do STF embasou-se nesse voto, por considerá-lo conciso e acertado, afirmando que o município de Nova Iguaçu assumiu o poder expropriante a incumbência de conservar o imóvel tombado. Durante o período em que o imóvel tombado esteve em poder do proprietário, não há como impor à União o dever de indenizar, agora, o espólio, pois o tombamento por si só não gera para o poder público obrigação de conservar ou indenizar, salvo em circunstâncias especiais. Como resultado, o relator da Segunda Turma do Supremo Tribunal Federal, por unanimidade de votos, não conheceu do recurso extraordinário. ${ }^{29}$

Ainda no Estado do Rio de Janeiro, em sua Capital, o proprietário de imóvel localizado no bairro Cosme Velho impetrou mandado de segurança contra ato do Prefeito Municipal do Rio de Janeiro, que se consubstancia no Decreto Municipal $n^{\circ}$ 7.046, de 28.10.1987, considerando "área de proteção ambiental do bairro Cosme velho e parte do bairro de Laranjeiras, na IV Região Administrativa - Botafogo". Alega que o Decreto referido restringiu o direito de propriedade do impetrante. Como resultado, o relator da Segunda Turma do Supremo Tribunal Federal, por maioria de votos, conheceu do recurso extraordinário e Ihe deu provimento para restabelecer, na sua plena eficácia, o

\footnotetext{
${ }^{28}$ MEIRELLES, Hely Lopes. Direito Administrativo Brasileiro, São Paulo: Malheiros, $1990,12^{\mathrm{a}}$. ed., p. 488

29 Número do processo: Recurso extraordinário no 16.917-0 Rio de Janeiro. Relator: FRANCISCO REZEK. Data do acórdão: 19/12/1996. Data da publicação: 06/06/1997
} 
Decreto 7.046, de 28.10.1987, editado pelo Prefeito do Município do Rio de Janeiro. 30

Em alguns processos, por sua vez, o autor da ação, por equívoco de interpretação das normas, ou por diferentes interpretações dos operadores do direito, não obtém êxito. É o caso, de 1958, em que houve uma ação cominatória, ajuizada pela União Federal, para impedir a construção de edifício no terreno ao lado do prédio da Igreja de Nossa Senhora da Glória do Outeiro, tombado. A Diretoria do Patrimônio Histórico e Artístico Nacional condicionou a execução do projeto à redução de sua altura para dez pavimentos, objetivando assegurar a proteção de visibilidade da referida Igreja, conforme art. 18 do Decr. - lei 25, de 30.11.1937. A ré alegou que está construindo edifício de 10 pavimentos, sobre pilotis, devidamente licenciado, e que acima do último pavimento constrói-se a casa de máquinas. Requereu a autora a imediata sustação das obras. O despacho do MM. Juiz condicionou a sustação à verificação de estarem sendo executadas em desrespeito às determinações administrativas. Segundo conclusão unânime dos peritos, "a visibilidade do templo não se prejudica com a construção". Assim, o juízo de primeiro grau julgou improcedente a ação e o Tribunal Federal de recursos e negou provimento aos apelos. Como resultado, o relator da Primeira Turma do Supremo Tribunal Federal, por decisão unânime, rejeitou o recurso, alegando que a Igreja da Glória do Outeiro nada sofreu com a construção. Esta não impedia ou reduzia a visibilidade do bem histórico tombado. ${ }^{31}$

Em outro caso, no município de Belo Horizonte, o Conselho Deliberativo do Patrimônio Cultural do município, em sessão ordinária de 10.11.1994, aprovou a inscrição no livro de Tombo Histórico dos Cine Pathé e Brasil, bem como o seu uso para atividade artístico-cultural. O problema aqui não foi o tombamento dos Bens, mas sim seu condicionamento de sua função, obrigatoriamente para fins artísticos e culturais. Os proprietários ajuizaram ação contra a limitação da

\footnotetext{
30 Número do processo: Recurso extraordinário no 121.140-7 - Rio de Janeiro. Relator: MAURÍCIO CORREA. Data do acórdão: 26/02/2002. Data da publicação: 23/08/2002.

${ }^{31}$ Recurso extraordinário no 38.663 - Distrito Federal. Relator: BARROS BARRETO. Data do acórdão: 14/08/1958. Data da publicação: 17/09/1958
} 
destinação às atividades artístico-culturais. $\mathrm{O}$ juízo de $1^{\circ}$ grau considerou $\mathrm{O}$ tombamento provisório dos ditos cinemas. Já o relator da Quinta Câmara Cível do Tribunal de Justiça de Minas Gerais deu provimento ao apelo dos proprietários, pois as disposições do texto das Notificações no 06 e 07/94 se referem ao uso para atividade artístico-cultural, "ferindo direito líquido e certo e de ser considerado ato ilegal de autoridade, por estarmos diante do tombamento de uso que, por ausência de previsão legal, fere o direito subjetivo do proprietário e o próprio princípio da legalidade". O relator do STF afirmou que os proprietários dos cinemas não se insurgiram contra o tombamento da edificação, mas contra a predeterminação da modalidade de seu uso pelo Poder Público, e que há inconstitucionalidade do emprego, pelo Poder Público, do chamado tombamento de uso. Como resultado, o relator da Primeira Turma do Supremo Tribunal Federal, por unanimidade de votos, negou o recurso extraordinário, por não reputar contrariados os princípios do art. 216, e seu parágrafo $1^{\circ}$, da Constituição. ${ }^{32}$

Há, ainda, dois interessantes processos no STF sobre leis estaduais. O primeiro é no estado do Rio Grande do Sul que, através da Lei estadual $n^{\circ}$ $11.380 / 99$, tentou passar por cima das competências constitucionais dos entes federativos, e atribuiu apenas aos municípios à responsabilidade e proteção dos sítios arqueológicos, bem como a guarda dos acervos existentes nas localidades. Esse caso será analisado no item sobre o papel dos Estados.

O outro caso é o do estado de Sergipe, cuja Constituição do Estado, promulgada em abril de 1967, continha vários artigos inconstitucionais. O caso foi analisado pelo STF em 1970 com base na Constituição de Federal de 1967, então vigente. Foram vários os artigos julgados inconstitucionais, interessandonos o artigo 12 que determinava caber ao Governo do Estado a nomeação dos Prefeitos dos municípios considerados patrimônio histórico e artístico nacional.

"art. 12 - Serão nomeados pelo Governo com prévia aprovação:

32 Número do processo: Recurso extraordinário no 219.292-1 - Minas Gerais. Relator: OCTÁVIO GALLOTTI. Data do acórdão: 07/12/1999. Data da publicação: 23/06/2000 
I - Da Assembléia Legislativa, o Prefeito da Capital e os dos Municípios considerados estância hidro-minerais em lei estadual, assim como das cidades incorporadas mediante tombamento ao patrimônio histórico e artístico nacional."

Estabeleceu, ainda, no artigo 76, competência privativa para nomear Secretários de Estado, Procurador Geral, além dos Prefeitos dessas cidades e os cargos de omissão.

"Art. 76

$(\ldots)$

IV - nomear e exonerar os Secretários de Estado, o Procurador Geral, o Prefeito da Capitã, dos Municípios hidrominerais, dos tombados ao patrimônio histórico e artístico nacional, os dirigentes das autarquias e dos ocupantes dos cargos de comissão."

Sobre o artigo 75, o Ministro Eloy da Rocha, em seu voto, lembra que o artigo 16 da CF de 1967 estabelece a autonomia municipal.

“Um dos seus pontos fundamentais é a eleição direta do Prefeito, Vice-Prefeito e Vereadores. Tal processo democrático de escolha só se exclui, quando se cuida de Prefeitos das Capitais dos Estados, dos Municípios, considerados estâncias hidrominerais ou em que prepondera o interesse da segurança nacional. (...) a Carta Estadual não só restringe a autonomia municipal, como se desvia do modelo federal. Patente a inconstitucionalidade do acréscimo acima assinalado." 33

${ }^{33}$ Representação 756. Supremo Tribunal Federal, 22.04.1970. Representante: Procurador Geral da República. Representada: Assembléia Legislativa do estado de Sergipe. Relator: Min. Evandro Lins e Silva 
b) Tribunais de Justiça e Superior Tribunal de Justiça

\section{TRIBUNAIS DE JUSTIÇA}

Os Tribunais de Justiça têm sua competência definida na Constituição do Estado, cabendo-lhes a organização judiciária. Essa Justiça, em nível estadual, tem competência residual, ou seja, os casos não contemplados pelas Justiças Especializadas (do Trabalho, Militar e Eleitoral) e da Justiça Federal (TRF I Juízes Federais).

Por isso, muitos casos analisados pelos Tribunais de Justiça são similares àqueles analisados pelo STF, pois também Ihes cabe analisar competência dos entes federativos, e cujos processos podem ou não ir para apreciação do STF se houver ou não recurso.

Como é o caso analisado pelo Tribunal de Justiça de Minas Gerais, da Apelação praticada por proprietário de um imóvel, contra o seu tombamento (sem justificativas) e argumentando ser inconstitucional a Lei de Tombamento n. 7.287, do Município de Juiz de Fora, por acreditar que tal ato não seria competência dos municípios, e sim exclusiva da União.

O Tribunal negou Provimento ao Recurso. Entendeu o sentenciante que os autores não lograram demonstrar que o imóvel não preenchia os requisitos necessários para sua preservação, uma vez que dispensaram a dilação probatória. No que se refere à incompetência do Município para legislar sobre matéria relativa a tombamento, ressaltou que "apesar de tal matéria ter sido reservada para a União, Estados e Distrito Federal, permaneceram os Municípios com a atribuição de exercer a proteção do patrimônio histórico e cultural em sua jurisdição, o que não impede possa promover o tombamento com base na legislação emanada das pessoas políticas competentes, ou que edite normas a respeito, procurando discipliná-lo no âmbito da sua competência". E concluiu que não basta para invalidar o ato administrativo do tombamento, o argumento de ser inconstitucional a Lei n. 7.287, do Município de Juiz de Fora, ou que a mesma não teria sido recepcionada pela Constituição 
de 1988, sem que se demonstre a infringência à legislação federal ou estadual. $^{34}$

Similar, há a contestação do ato de tombamento de imóvel localizado no município de Belo Horizonte, alegando-se os proprietários não terem recebido as devidas justificativas para o ato (estudo, parecer, etc), bem como contestase o valor histórico e cultural do imóvel. Entretanto, considerou-se, conforme a lei municipal de tombamento, não ser necessária a entrega das referidas justificativas, juntamente com o comunicado da abertura do processo de tombamento. Considerou-se também que o referido imóvel possui características históricas importantes, indicando, como manifestou o relator, "com clareza a dinâmica histórica da ocupação do bairro de Santa Tereza, marcando duas épocas distintas e expressivas: os anos 30 e os anos 50 . Ademais, os referidos galpões atestam um caráter histórico mais significativo, evocando a tradição suburbana rural que a região teve originalmente em seu período de Colônia Agrícola". Sem do assim, foi negado o recurso contrário ao tombamento do imóvel. ${ }^{35}$

Também contestando o tombamento de imóvel, proprietários de Bem em processo de tombamento no município de Uberlândia, entram com mandado de segurança, com liminar solicitando que seu imóvel, em estudo de tombamento pelo Conselho Municipal de Patrimônio Histórico, Artístico e Cultural, seja liberado pela Prefeitura Municipal para demolição. Alega-se a demora para o resultado final do tombamento ou não do imóvel. O TJ garantiu a manutenção do processo, negando o provimento ao recurso. ${ }^{36}$

\footnotetext{
34 Número do processo: 000256230-4/00(1). Relator: BADY CURI. Data do acórdão: 07/11/2002. Data da publicação: 26/02/2003

35 Número do processo: 000192352-3/00(1). Relator: ALMEIDA MELO. Data do acórdão: 14/12/2000. Data da publicação: 15/02/2001

${ }^{36}$ Número do processo: 000283475-2/00(1). Relator: ALMEIDA MELO. Data do acórdão: 13/02/2003. Data da publicação: 08/04/2003
} 
O Superior Tribunal de Justiça é composto de no mínimo 33 juízes nomeados pelo Presidente da República, depois de aprovados pelo Senado. Para Araújo (2002: 329) o STJ tem o papel de "guardião do direito federal, transformando-o em última instância de jurisdição quando a questão em debate relacionar-se com o direito federal". Mais especificamente, sua competência pode ser "originária", de julgar; e "recursal", quando advém dos recursos "ordinários" e "especiais", conforme estabelecido no artigo 105 da Constituição Federal. A maioria dos casos por nós analisados está nesse último caso, ou seja, recursal e especial ${ }^{37}$.

Como exemplo temos um caso de destruição de sítios, como o ocorrido no RS, de destruição de dunas de areia e de sítios arqueológicos "com cerâmica indígena da Tradição Vieira" 38 em 1992, no município de Torres, pelo Clube de Caçadores do Rio Grande do Sul, e que gerou Ação Civil Pública. O primeiro problema recaiu na contestação da competência do caso ser analisado no juízo da própria cidade. O resultado foi "por unanimidade, conhecer do conflito e declarar competente o juízo de direito da 1a. Vara Cível de Torres - RS, suscitado". ${ }^{39}$

O MM. Juiz julgou procedente a ação e determinou ao réu "abster-se de destruir o meio ambiente e ao patrimônio cultural, condenando-o ao pagamento de indenização ao erário público - pelo quantum a ser definido em liquidação por ter causado os referidos danos". ${ }^{40}$

37 CF, Art. 105:

(...)

a) contrariar tratado ou lei federal, ou negar-Ihes vigência;

b) julgar válida lei ou ato de governo local contestado em face de lei federal;

c) der a lei federal interpretação divergente da que lhe haja atribuído outro tribunal.

38 Processo RESP 115599/RS. RECURSO ESPECIAL 1996/0076753-0. Ministro RUY ROSADO DE AGUIAR. Data do Julgamento: 27/06/2002

39 Processo CC 12361/RS. CONFLITO DE COMPETENCIA - 1995/0000084-9. Relator: Ministro AMÉRICO LUZ

40 Recurso Especial n 115.599 - RS (1996/076753-0). Relator: Min. Ruy Rosado de Aguiar. Ministério Público do Rio Grande do Sul. 
O réu apelou, aduzindo que os danos se deram tão somente em face do não conhecimento da existência, naquela região, de áreas com sítios arqueológicos. Após receber provimento parcial da Segunda Câmara Cível do Tribunal de Justiça do Rio Grande do Sul, para afastar a indenização, o MP interpôs recurso extraordinário e especial, que foi acolhido, cassado o recurso e restabelecida a sentença original conforme justificou o representante do MPF:

\begin{abstract}
"diante da efetiva comprovação nestes autos da relação de causalidade entre a conduta do recorrido e a ocorrência do dano ao meio ambiente, forçoso seria concluir pela condenação da entidade ré ao pagamento da indenização prevista no artigo $225, \S 3^{\circ}$, da Carta Magna, mesmo porque, em se tratando de dano ambiental, tanto a doutrina quanto a jurisprudência têm entendido que a responsabilidade expressa no artigo $14, \S 1^{\circ}$, da Lei $6.938 / 81$ é objetiva, logo, independe da comprovação de culpa."
\end{abstract}

O processo foi enviado à Segunda Seção do Ministério Público Estadual do Estado do Rio Grande do Sul, que é a Secção competente para analisar matéria relativa a pagamento e indenização por dano ao meio ambiente. A autoria do crime ficou referenciada, como exemplo as justificativas recorrentes de desconhecimento da existência dos sítios. Aponta o Relator:

"Não se admite a versão de que entidade não provocou os danos, ou não tinha conhecimentos da importância histórica dos elementos que afloravam nas areias. Em primeiro lugar, quanto à efetivação de estragos, em 10 de julho de 1992, o Coordenador de arqueologia do Centro de Cultura de pessoas, flagrou empregados contratados pelo requerido destruindo a duna, a fim de 'efetuar o plantio de vegetação rasteira' (fl. 15). Ademais, as fotos revelam uma realidade indesmentível, como a de fl. 28 , onde de constata a retirada da areia". 
E continua:

"Assim, embora desnecessária a comprovação do elemento culpa para a verificação da responsabilidade pelo dano ambiental, conforme é da nossa jurisprudência, também ele se encontra na hipótese em exame:"

"O poluidor é obrigado, independentemente de culpa, a indenizar ou reparar os danos causados ao meio ambiente e a terceiros, afetados por sua atividade" (REsp $\mathrm{n}^{0}$ 20.401/SP, 2a Turma, rel. o em. Min. Helio Mosimann, DJ 21/03/1994; no mesmo sentido o REsp 20.401/SP e o AGA $179.321 / \mathrm{SP}) .^{41}$

O processo foi julgado em 2002 e o autor da destruição do sítio arqueológico e das dunas onde ele se localizava foi condenado a "indenizar pelos prejuízos causados". ${ }^{42}$

c) Tribunal Regional Federal

Conforme o artigo 106 da CF, a Justiça Federal está organizada através dos Tribunais Regionais Federais e dos Juízes Federais. Aos TRFs compete processar e julgar casos da esfera federal, bem como em grau de recurso os casos decididos pelos juízes federais e estaduais definidos no art. 108 da CF. Já aos juizes federais compete julgar as causas em que a União é a autora ou ré, e outros casos estabelecidos no art. 109 da CF.

\footnotetext{
${ }^{41}$ Jurisprudência baseada no Art. 14 da Lei 6938/81:

$\S 1^{\circ}$ - Sem obstar a aplicação das penalidades previstas neste artigo, é o poluidor obrigado, independentemente da existência de culpa, a indenizar ou reparar os danos causados ao meio ambiente e a terceiros, afetados por sua atividade. $\mathrm{O}$ Ministério Público da União e dos Estados terá legitimidade para propor ação de responsabilidade civil e criminal, por danos causados ao meio ambiente."

42 Processo RESP 115599/RS. RECURSO ESPECIAL 1996/0076753-0. Ministro RUY ROSADO DE AGUIAR. Data do Julgamento: 27/06/2002
} 
O Tribunal Regional Federal já analisou casos de destruição de sítios arqueológicos, como o ocorrido em Manaus - AM, onde as obras de um conjunto habitacional provocaram a destruição de um sítio arqueológico com urnas funerárias e outros artefatos. Na ocasião, o Ministério Público Federal ajuizou Ação Civil Pública, sendo a Superintendência de Habitação e Assuntos Fundiários - SUHAB e os demais réus condenados a adoção de diversas providências imediatas destinadas à conservação da área, bem como custear os estudos do local para a determinação dos danos causados.

A SUHAB entrou com agravo de instrumento ${ }^{43}$ contra a decisão da Ação Civil Pública. Em resposta, o Ministério Público Federal ${ }^{44}$ apresentou contraminuta esclarecendo o caso e informando do não cumprimento das determinações da Ação pela SUHAB, apesar dos "esforços despendidos pelo IPHAN e IBAMA em coordenar os réus no cumprimento da liminar", ressaltando que as obras de construção do conjunto "não foram precedidas do necessário estudo de impacto ambiental".

Em seu voto, a Relatora, Desembargadora Federal Maria Isabel Gallotti Rodrigues, negou provimento ao agravo.

Temos também um processo no qual, apesar das acusações, os réus foram absolvidos. O caso ocorreu em maio de 1989 com a destruição, através de explosivos, de um "arco calcário" com pinturas rupestres localizado na Fazenda Caxambu, município de Matozinhos, Estado de Minas Gerais. A destruição foi feita utilizando-se explosivos, pela empresa de mineração CALSETE, cujo proprietário também era sócio na fazenda.

O Juiz julgou procedente a denúncia do Ministério Público Federal e condenou os réus a dois anos e seis meses de detenção, pela prática de crime de dano qualificado.

\footnotetext{
${ }^{43}$ Agravo de Instrumento $n^{\circ}$ 2004.01.00.002571-6/AM. Tribunal Regional Federal da $1^{\text {a }}$ Região. Data: 15/02/2004

${ }^{44}$ Parecer do Procurador Regional da República Paulo Gustavo Gonet Branco. MPF fls. $106 / 108$
} 
Ocorre que o referido sítio havia sido identificado pelo IEPHA em outubro de 1988, ocasião em que o arco foi fotografado, mas não sendo o sítio cadastrado no IPHAN ou tombado pelo IEPHA.

Consta nos autos do processo que foi realizada perícia técnica no local dos escombros e nenhum bloco de granito encontrado continha pinturas rupestres.

Assim, os réus apelaram ${ }^{45}$ alegando que não estava comprovada a materialidade do delito e tentaram desqualificar a funcionária do IEPHA que atestava que havia pinturas rupestres no arco explodido. Também justificou-se que o sítio "não se encontrava tombado pelo IEPHA ou mesmo cadastrado", dentre outros argumentos.

O relator, Juiz Osmar Tognolo, estando de acordo com a Procuradora Regional Maria Eliane Menezes de Faria, do MPF, lembra que não é necessário o registro ou tombamento do sítio arqueológico para sua proteção.

Aliás, conforme Damásio de Jesus, a lei 3924/61

\begin{abstract}
"considera delito contra o patrimônio nacional a destruição ou mutilação de monumentos arqueológicos ou préhistóricos. A destruição, inutilização ou deterioração causados a eles será crime descrito no artigo 163, parágrafo único, III, do código Penal, não dependendo a existência da infração do 'registro' do monumento pela Diretoria do Patrimônio Histórico e Artístico Nacional, Havendo registro, o crime será o previsto no art. 165 do Código Penal” ${ }^{\text {46 }}$
\end{abstract}

Entretanto, ao considerar a falta de estudos do local antes da destruição, o fato da perícia não encontrar vestígios das pinturas rupestres nos blocos restantes

\footnotetext{
${ }^{45}$ Apelação Criminal n 94.01.03974-7-MG. Tribunal Regional Federal. 1ª Região

${ }^{46}$ DAMÁSIO DE JESUS. Código Penal Anotado. São Paulo: Ed. Saraiva, 3ª Ed. p. 513.
} 
e de que a única prova era a fotografia feita pelo IEPHA, optou por não condenar os apelantes, justificando:

"É que sem esses dois requisitos - existência das pinturas e seu valor arqueológico -, resta descaracterizado o sítio arqueológico, com o que deixa de existir propriedade da União Federal, e para a tipificação do crime de dano é indispensável que o bem atingido pertença a terceiro. Não se pode, evidentemente, condenar alguém pelo crime de dano causado ao seu próprio patrimônio".

Por sua vez, o voto do Juiz Olindo Menezes causa espanto ao afirmar que a necessidade de preservação se justificaria apenas se houvesse tombamento. $E$ que o sítio não seria propriedade da União, derivando apenas de um dispositivo de lei, a 3924/61. E acrescenta:

"Isso não seria o suficiente para obrigá-lo a preservar o arco de pedra (onde estaria a inscrição). Teria que haver um estudo técnico a respeito, com a consequente formalização da limitação ao uso de propriedade. Além do mais, sabe-se que os órgãos encarregados da preservação do patrimônio histórico pouco fazem nesse sentido.

A única preocupação é a de punir os donos de imóveis, quando, em razão de necessidades urgentes de conservação, fazem eles alguma intervenção. Se a União se considerava dona do sítio onde estava o arco de calcário, que tomasse todas as providências necessárias à sua conservação."

Com razão, o Ministério Público Federal apelou da decisão, sustentando que "o acórdão teria sido omisso" por não examinar as provas constantes dos autos e lembra que a Lei 3924/61, em seu art. $3^{\circ}$, veda a destruição de sítios e pinturas rupestres antes mesmo de serem pesquisados. 
Entretanto, infelizmente, os argumentos não convenceram o Relator, sendo rejeitados e prevalecendo a decisão de absolver os réus. 


\title{
2.4 O papel dos Estados
}

Como já dissemos anteriormente, a Constituição Federal enumerou as competências da União e dos Municípios, cabendo aos Estados as remanescentes. Há, entretanto, competências concorrentes com a União e o Distrito Federal na proteção do Patrimônio, como o art. 24, §§ 7 e $8^{47}$.

Cada Estado deve possuir sua própria Constituição e leis, observando-se os princípios da Constituição (art. 25).

Em São Paulo, a Constituição do Estado incumbe ao Poder Público a obrigação de proteger o patrimônio cultural e artístico, ao prever em seu artigo 261:

\begin{abstract}
"O Poder Público pesquisará, identificará, protegerá e valorizará o patrimônio cultural paulista, através do Conselho de Defesa do Patrimônio Histórico, Arqueológico, Artístico e Turístico do Estado de São Paulo, CONDEPHAAT, na forma que a lei estabelecer".
\end{abstract}

Recentemente, a Secretaria Estadual de Meio Ambiente publicou a Resolução SMA - 34, de 27-8-2003, que "dispõe sobre as medidas necessárias à proteção do patrimônio arqueológico e pré-histórico quando do licenciamento ambiental de empreendimentos e atividades potencialmente causadores de significativo impacto ambiental, sujeitos à apresentação de EIA/RIMA, e dá providências correlatas". Esta resolução surgiu principalmente em função da Portaria IPHAN 230/02, que buscou compatibilizar as fases de obtenção de licenças ambientais em urgência com os estudos preventivos de arqueologia, objetivando o licenciamento de empreendimentos potencialmente capazes de afetar 0 patrimônio arqueológico.

\footnotetext{
47 "VII - proteção ao patrimônio histórico, cultural, artístico, turístico e paisagístico;

VIII - responsabilidade por dano ao meio ambiente, ao consumidor, a bens e direitos de valor artístico, estético, histórico, turístico e paisagístico".
} 
Ainda é cedo para uma avaliação da Resolução SMA 34. Em primeiro lugar, é positiva porquê o Estado está assumindo sua responsabilidade de proteger o patrimônio arqueológico estadual. Entretanto, ao contrário da Portaria IPHAN 230, que determina o diagnóstico arqueológico em áreas com projetos que requeiram licenciamentos ambientais, a Resolução SMA 34 defende que no Estado de São Paulo tais estudos arqueológicos somente se aplicam em áreas de empreendimentos que necessitem de EIA/RIMA quando já se conheçam vestígios arqueológicos no local (art. 1, Parágrafo Único).

$$
\begin{aligned}
& \text { Parágrafo único - Os procedimentos previstos nesta } \\
& \text { Resolução somente se aplicam a outros estudos } \\
& \text { ambientais, tal como fixado no artigo } 1^{\circ} \text {, inciso III, da } \\
& \text { Resolução CONAMA } n^{\circ} 237 / 97 \text {, se forem constatados } \\
& \text { indícios, informações ou evidências da existência de sítio } \\
& \text { arqueológico ou pré-histórico. }
\end{aligned}
$$

Alguns argumentam que tal interpretação seria um equívoco. Seus desdobramentos e correta interpretação será observada com o passar do tempo, com casos concretos.

Já o Estado do Rio Grande do Sul, através da Lei estadual n 11.380/99, tentou passar por cima das competências constitucionais dos entes federativos, e atribuiu apenas aos municípios à responsabilidade e proteção dos sítios arqueológicos, bem como a guarda dos acervos existentes na localidade.

Art. $1^{\circ}$ - Os sítios arqueológicos, bem como o seu acervo, existentes no Estado, ficam sob a proteção, guarda e responsabilidade dos municípios em que se localizam.

Rio Grande do Sul já possuía a Lei 7231/78, que dispunha sobre o patrimônio cultural do Estado, onde em seu artigo $1^{\circ}$ os bens culturais, inclusive os bens arqueológicos, são "objeto de seu especial interesse e cuidadosa proteção". Também expressava em seu art. $3^{\circ}, \S$ b que o Estado deve promover a 
celebração de convênios com a União e os Municípios para ação conjunta para a proteção do patrimônio cultural.

Em 1983, através do Decreto no 31049 o Governo do Estado criou o Sistema Estadual de Preservação do Patrimônio Cultural, organizando a estrutura administrativa responsável pelas políticas de preservação do Patrimônio Cultural e as ações de competência material do Estado.

Em 2002, o próprio Governo do Estado do Rio Grande do Sul propõe ação direta de inconstitucionalidade ${ }^{48}$, com pedido de suspensão cautelar, para a Lei no 11.380/99. Para a ação, o Governo do RS considera:

"No caso, o que se tem é a presença de disposição que compromete o equilíbrio que deve existir entre as três pessoas e a União de competência que constitucionalmente é sua, sobrecarregando o município desnecessariamente".

"De outra parte, o equilíbrio federativo se vê afetado porque a operacionalização pode perfeitamente ser feita via convênio, como prevê a lei federal de regência, descabendo ao EstadoMembro derrogar disposição que o Constituinte originário reservou à lei complementar".

"Ainda, a própria autonomia municipal de vê afetada, porquanto ao se carrear a responsabilidade pelos sítios arqueológicos, com exclusividade, ao Município, passa-se a exigir destes a mobilização de recursos materiais e humanos que podem estar além das respectivas possibilidades reais. E, por outro lado, uma medida desta natureza traduz uma autêntica intervenção no Município, que poderia render ensejo, inclusive, a intervenção federal".

\footnotetext{
${ }^{48}$ Ação Direta de Inconstitucionalidade $n^{0}$ 2.544-0
} 
Por outro lado, a Assembléia Legislativa do Estado do Rio Grande do Sul, autora do Projeto de Lei no 11.380/99, defende-se, justificando suas propostas, mas complicando-se ainda mais com argumentos descabidos:

"Pelo que se vê, da análise do projeto que se transformou na Lei no 11.380, não há no Rio Grande do Sul sítios arqueológicos de vulto, que mereçam a preocupação do Poder Executivo na ADIN $^{49}$ que impetrou. Existem apenas alguns sinais, reminiscências de eras históricas, acervos que os municípios já vêm guardando e se responsabilizando. Evidentemente que se fosse descoberto um grande sítio, o Estado e até a União seriam chamadas a participar, face a importância do evento. De maneira que não se vê nenhuma justificativa jurídica a embasar o pedido de decretação de Lei Inconstitucional, como pretende o Senhor Governador. A Constituição Federal não veda a primazia do município em questões atinentes a sítios arqueológicos. Prevê, sim, a atuação conjunta, o que certamente se fará, pois dificilmente o município tomaria medidas, em descobertas de vulto, sem o concurso das outras esferas de poder. Fica o município com a responsabilidade da guarda e proteção daquilo que vier a ser descoberto, o que se compreende até porque fica em seu território e é ele o primeiro interessado, o diretamente interessado na preservação do acervo encontrado".

Finalmente, o Relator, Ministro Sepúlveda Pertence, manifesta que:

"regular a cooperação não abrange o poder de demitiremse a União ou os Estados dos encargos constitucionais de proteção dos bens de valor arqueológico para descarregalos ilimitadamente sobre os Municípios.

\footnotetext{
${ }^{49}$ ADIN - Ação Direta de Inconstitucionalidade
} 
As razões do requerente convencem, por outro lado, da conveniência da medida liminar: o apequenamento do patrimônio arqueológico gaúcho não parece confirmado pelo levantamento do IPHAN, que instrui a petição inicial.

Defiro a medida cautelar e suspendo a eficácia da L. est. 11.380-rs de 03/11/99: é meu voto".

A decisão do Relator foi também unânime entre os ministros do STF em junho de 2002.

Talvez o melhor exemplo do exercício de sua competência na área do Patrimônio Cultural seja dado pelo Estado de Minas Gerais. A responsabilidade pelo gerenciamento do patrimônio cultural do Estado é do Instituto Estadual do Patrimônio Histórico e Artístico de Minas Gerais - IEPHA, criado em 1971 pela Lei Estadual $\mathrm{n}^{\circ} 5.775$, de 30 de setembro de 1971, e alterada pelas Leis Estaduais no 8.828, de 5 de julho de 1985 e no 11258, de outubro de 1993.

O IEPHA tem muitos pontos em comum com outros órgãos estaduais da área. Entretanto, o que mais diferencia o Estado de Minas Gerais e, conseqüentemente, o IEPHA, é a existência da Lei Estadual no 13.803/00. Esta lei, que substituiu a Lei $n^{\circ}$ 12.040/95, dispõe sobre a distribuição da parcela de receita do produto da arrecadação do ICMS pertencente aos municípios, de que trata o inciso II do parágrafo único do artigo 158 da Constituição Federal ${ }^{50}$.

A Lei atribui ao IEPHA a responsabilidade e gerenciamento do critério patrimônio cultural para a distribuição de 4\% da arrecadação mensal do ICMS, entre os municípios que atuarem de acordo com as determinações legais e com as diretrizes definidas pelo IEPHA e aprovados por seu Conselho Curador.

${ }^{50}$ Constituição Federal de 1988. Artigo 158:

(...) Parágrafo único. As parcelas de receita pertencentes aos Municípios, mencionadas no inciso IV, serão creditadas conforme os seguintes critérios:

I - três quartos, no mínimo, na proporção do valor adicionado nas operações relativas à circulação de mercadorias e nas prestações de serviços, realizadas em seus territórios;

II - até um quarto, de acordo com o que dispuser lei estadual ou, no caso dos Territórios, lei federal. 
O IEPHA/MG é uma Fundação Pública, sem fins lucrativos, com autonomia administrativa e financeira, isenta de tributação estadual. Possui os privilégios legais atribuídos às entidades de utilidade pública e um Conselho Curador que decide sobre os tombamentos.

O IEPHA está estruturado em três diretorias, submetidas à presidência do órgão, que conta ainda com as assessorias de Comunicação, Jurídica e de Planejamento e Coordenação. Compete a cada diretoria:

- Diretoria de Conservação e Restauração - trata dos assuntos relacionados à análise e elaboração de projetos de intervenção em bens tombados pelo IEPHA/MG e obras em bens móveis e imóveis. É composta pelas Superintendências de Análise de Projetos, Apoio Técnico, Elementos Artísticos e Patrimônio Edificado.

- Diretoria de Proteção e Memória - trata dos assuntos relacionados a tombamentos, pesquisa, arquivo e biblioteca e implementação de programas de proteção ao patrimônio cultural. É composta pelas Superintendências de Desenvolvimento e Promoção, Documentação Histórica, Pesquisa e Proteção.

- Diretoria Administrativa e Financeira - trata dos assuntos relacionados à contabilidade, finanças, patrimônio próprio, recursos humanos, transporte e serviços. É composta pelos Departamentos de Contabilidade, Financeiro, Material e Patrimônio, Recursos Humanos e Transportes e Serviços ${ }^{51}$.

Para que se entenda melhor essa Lei, o Governo de Minas Gerais reserva 4\% do valor arrecadado pelo ICMS e que deve ser repassado aos municípios. O valor correspondente aos 4\% do ICMS arrecadado será distribuído entre os municípios que possuam políticas de preservação do patrimônio cultural, conforme os critérios estabelecidos pelo IEPHA. Nesse sentido, cada ação na preservação do patrimônio tem uma certa pontuação. Assim, os 4\% do ICMS serão divididos proporcionalmente entre os municípios inscritos no programa, conforme a pontuação atingida naquele ano.

\footnotetext{
51 IEPHA. Diretrizes para a proteção do patrimônio cultural de Minas Gerais. Belo
} Horizonte, 2001. 
A pontuação em cada município é calculada pela porcentagem estabelecida nos Quadros I e III anexos das notas referentes aos Atributos constantes do Anexo III da Lei 13.803/2000 que estabelece os Índices de Patrimônio Cultural - PPC para Núcleo Histórico (NH), Conjunto Paisagístico (CP), Bens Imóveis (BI) ou Bens Móveis (BM) e a porcentagem estabelecida no Quadro IV anexo, da nota referente ao Atributo constante do Anexo III da Lei 13.803/2000 que estabelece os Índices de Patrimônio Cultural - PPC para Existência de Planejamento de Política Municipal de Proteção do Patrimônio Cultural (PCL) ${ }^{52}$. Os quadros a seguir são os utilizados pelo IEPHA e encontram-se na Deliberação Normativa do Conselho Curador do IEPHA/MG para o Exercício de 2003.

${ }^{52}$ Deliberação Normativa do Conselho Curador do IEPHA/MG para o Exercício de 2003. 
Quadro I - DOSSIÊS DE TOMBAMENTOS E LAUDOS DE ESTADO DE CONSERVAÇÃO

\begin{tabular}{|c|c|c|c|c|}
\hline $\begin{array}{c}\text { Document } \\
0\end{array}$ & & Características exigidas para efeito de pontuação & \multicolumn{2}{|c|}{$\begin{array}{c}\begin{array}{c}\text { Porcentagem em relação às } \\
\text { notas referentes } \\
\text { aos atributos siglas } \\
\text { NH. CP. BI. e } B M\end{array}\end{array}$} \\
\hline 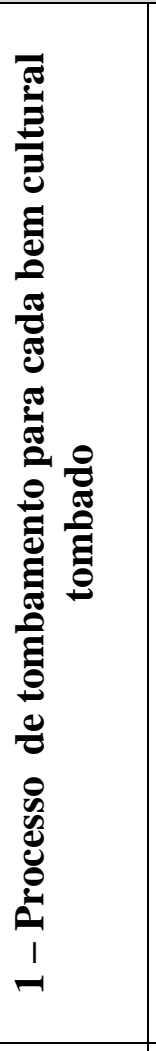 & & 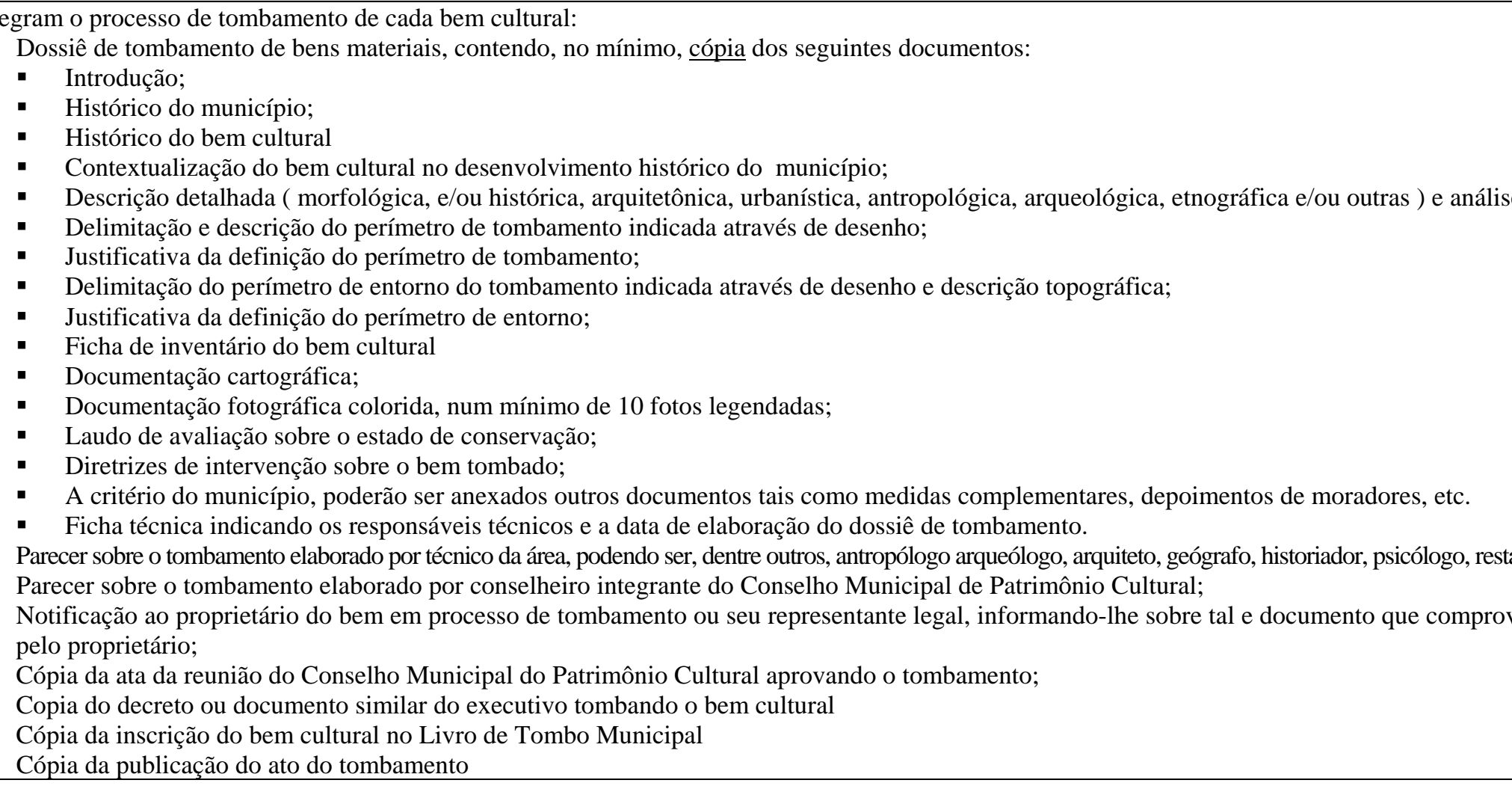 & $\begin{array}{l}\text { do bem cultural; } \\
\text { rador, sociólogo, etc } \\
\text { o seu recebimento } \\
\end{array}$ & $30 \%$ \\
\hline 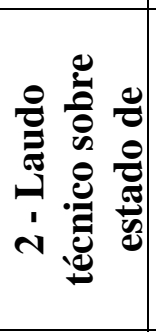 & & $\begin{array}{l}\text { laudos técnicos referentes aos bens tombados devem ser elaborados em data posterior a } 15 \text { de fevereiro de 2002, segundo roteiro divulga } \\
\text { ponsáveis técnicos conforme habilitação para as seguintes categorias de bem tombado: } \\
\text { - Estruturas arquitetônicas e urbanísticas - arquiteto urbanista ou engenheiro civil. } \\
\text { - Sítios naturais- biólogo, geólogo, engenheiro agrônomo, engenheiro florestal, engenheiro agrimensor ou arquiteto. } \\
\text { - Sítios arqueológicos - arqueólogo. } \\
\text { - } \quad \text { Bens móveleológicos - espeleólogo integrados - arquiteto, historiador, ou conservador/restaurador } \\
\text { Acervo documental - historiador, bibliotecário, arquivista ou restaurador. }\end{array}$ & pelo IEPHA, por & \\
\hline
\end{tabular}


QUADRO III

AÇÕES DE PROTEÇÃO E INVESTIMENTOS

\section{ATUAÇÃO NA PRESERVAÇÃO DE BENS CULTURAIS}

\begin{tabular}{|c|c|c|}
\hline Documento & $\begin{array}{c}\text { Características exigidas para efeito de } \\
\text { pontuação }\end{array}$ & $\begin{array}{l}\text { Porcentagem em } \\
\text { relação às notas } \\
\text { referentes aos } \\
\text { atributos siglas } \\
N H . C P . B I . \text { e } B M\end{array}$ \\
\hline $\begin{array}{l}1 \text { - Atuação do } \\
\text { Setor de Patrimô- } \\
\text { nio Cultural ou } \\
\text { órgão afim }\end{array}$ & $\begin{array}{l}\text { Apresentação de relatório de atividades do } \\
\text { Setor de Patrimônio Cultural ou órgão } \\
\text { afim elaborado conforme roteiro divulgado } \\
\text { pelo IEPHA indicando a atuação do setor na } \\
\text { proteção do acervo cultural do município. }\end{array}$ & $30 \%$ \\
\hline \multirow{2}{*}{$\begin{array}{c}2 \text { - Relatório de } \\
\text { Investimentos } \\
\text { dos recursos } \\
\text { recebidos no ano } \\
\text { de } 2001 \text { em bens } \\
\text { ou atividades } \\
\text { culturais }\end{array}$} & $\begin{array}{l}\text { Comprovar investimentos em bens móveis ou } \\
\text { imóveis através de relatórios de } \\
\text { investimentos conforme modelo divulgado } \\
\text { pelo IEPHA/MG com apresentação em anexo } \\
\text { de empenhos, notas fiscais e/ou contratos de } \\
\text { prestação de serviços e documentação que } \\
\text { comprove a realização das atividades } \\
\text { relacionadas aos gastos, podendo ser fotos, } \\
\text { notícias de mídia impressa, vídeos. }\end{array}$ & $30 \%$ \\
\hline & $\begin{array}{l}\text { Comprovar investimentos em atividades } \\
\text { culturais através de relatórios de } \\
\text { investimentos conforme modelo divulgado } \\
\text { pelo IEPHA/MG com apresentação em anexo } \\
\text { de empenhos, notas fiscais e/ou contratos de } \\
\text { prestação de serviços e documentação que } \\
\text { comprove a realização das atividades } \\
\text { relacionadas aos gastos, podendo ser fotos, } \\
\text { notícias de mídia impressa, vídeos. } \\
\text { Nota: Para efeito desta pontuação, são } \\
\text { entendidos como bens móveis ou imóveis, } \\
\text { bens culturais materiais tombados e/ou } \\
\text { inventariados, e como atividades culturais, } \\
\text { atividades relacionadas às artes visuais, artes } \\
\text { plásticas, à educação patrimonial artes } \\
\text { gráficas, artes musicais, literatura, dança, } \\
\text { exposições, festivais, festas folclóricas ou } \\
\text { tradicionais, museus, arquivos, bibliotecas ou } \\
\text { similares. }\end{array}$ & $10 \%$ \\
\hline
\end{tabular}


QUADRO IV - Valor Total - 3 pontos

EXISTÊNCIADEPLANEJAMENTODEPOÚTCAMUNICIPALDEPROTEÇÃODOPATRIMÔNIOCULTURAL

ATUAÇÃO NA PRESERVAÇÃO DE BENS CULTURAIS.

\begin{tabular}{|c|c|c|}
\hline Item & Características mínimas exigidas para efeito de pontuação & \begin{tabular}{|l} 
Porcentagem \\
em relação á \\
nota referen- \\
te ao atributo \\
sigla PCL \\
\end{tabular} \\
\hline $\begin{array}{l}\text { 1-Legisla- } \\
\text { ção munici- } \\
\text { pal de pro- } \\
\text { teção ao } \\
\text { Patrimônio } \\
\text { Cultural. }\end{array}$ & $\begin{array}{l}\text { O município deverá apresentar cópia da publicação da Lei } \\
\text { municipal específica criando o instituto do tombamento no nível } \\
\text { municipal. }\end{array}$ & $5 \%$ \\
\hline $\begin{array}{c}2- \\
\text { Existência } \\
\text { de } \\
\text { Conselho } \\
\text { Municipal } \\
\text { do } \\
\text { Patrimô- } \\
\text { nio } \\
\text { Cultural }\end{array}$ & $\begin{array}{l}\text { O município deverá encaminhar apenas no ano de sua criação, } \\
\text { cópia dos seguintes documentos: } \\
\text { 1. de criação do conselho, podendo ser decreto municipal, lei } \\
\text { municipal específica, ou capítulo específico da lei orgânica } \\
\text { municipal; } \\
\text { 2. do regimento interno do Conselho ou documento similar, onde } \\
\text { deverão constar no mínimo as formas de convocação, } \\
\text { deliberação e periodicidade de suas reuniões. Caso haja } \\
\text { alterações, as retificações deverão ser encaminhadas no ano de } \\
\text { sua aprovação. } \\
\text { O município deverá encaminhar anualmente cópia dos seguintes } \\
\text { documentos: } \\
\text { 1. das atas que comprovem a atuação do Conselho, com } \\
\text { periodicidade mínima bimestral a partir da sua data de criação e } \\
\text { assinada pelos membros presentes. } \\
\text { 2. de nomeação de seus integrantes, recomendando apresentar } \\
\text { composição equilibrada entre o poder público e de entidades e } \\
\text { instituições representativas da sociedade civil. } \\
\text { 3e informação sobre o ano em que foi criado o Conselho e de } \\
\text { aprovação do regimento em vigor. }\end{array}$ & $20 \%$ \\
\hline $\begin{array}{c}3- \\
\text { Setor de } \\
\text { Patrimôni } \\
\text { o Cultural } \\
\text { com } \\
\text { equipe } \\
\text { técnica } \\
\text { especializa } \\
\text { da }\end{array}$ & $\begin{array}{l}\text { O município deverá informar qual o setor responsável, dentro de } \\
\text { seu organograma, pela gestão da Política Municipal de } \\
\text { Proteção ao Patrimônio Cultural. Deverá constar da informação, } \\
\text { o nome do setor, o nome e a formação profissional do gerente, } \\
\text { endereço e telefone para contato, e o email do setor ou da } \\
\text { Prefeitura, se houver. } \\
\text { Os municípios que não tiverem em seus quadros funcionais um } \\
\text { arquiteto ou um historiador, deverão contratar um destes } \\
\text { profissionais sob regime de consultoria. O consultor deverá ter } \\
\text { conhecimento em patrimônio cultural, comprovada através de } \\
\text { currículo. }\end{array}$ & $35 \%$ \\
\hline $\begin{array}{l}\text { 4- } \\
\text { Execução } \\
\text { de } \\
\text { Inventário }\end{array}$ & $\begin{array}{l}\text { 1. Elaborar o inventário de acordo com o roteiro constante do } \\
\text { Quadro II. }\end{array}$ & $40 \%$ \\
\hline
\end{tabular}


O número de municípios pontuados pela lei vem aumentando gradualmente, conforme se pode observar no quadro abaixo:

\begin{tabular}{|c|c|c|c|c|c|c|c|c|c|}
\hline \multicolumn{7}{|c|}{ NÚmERO DE MUNICÍPIOS PONTUADOS } \\
\hline 1996 & 1997 & 1998 & 1999 & 2000 & 2001 & 2002 & 2003 & 2004 & $2005^{53}$ \\
\hline 106 & 122 & 167 & 187 & 186 & 218 & 334 & 356 & 454 & 392 \\
\hline
\end{tabular}

Os municípios podem obter pontos a partir da existência de bens tombados em nível federal e estadual ou a partir de ações próprias. No último caso, o município deve ter uma estrutura mínima para pleitearem a pontuação. Assim, cada município deve ter, pelo menos, os seguintes itens:
a) Lei municipal de tombamento;
b) Conselho Municipal de Patrimônio Cultural;
c) Órgão gestor oficial de Patrimônio Cultural.

O IEPHA presta assistência aos municípios para a implantação das políticas de Patrimônio Cultural, fornecendo modelos de leis de tombamento, de criação de Conselhos de Patrimônio Cultural, inventários, etc.

A partir dessas ações municipais e de ações próprias, o IEPHA vem desenvolvendo o Inventário do Patrimônio Histórico e Artístico Nacional - IPAC. Os inventários constituem importante ferramenta na preservação de Bens Culturais.

Embora a Lei Estadual $n^{\circ} 13.803 / 00$ seja bastante abrangente, o patrimônio arqueológico foi inserido de forma periférica. Tal patrimônio somente será pontuado nas seguintes condições:

\footnotetext{
${ }^{53}$ 2005: Dados obtidos em Janeiro.
} 

a) Se o sítio arqueológico for tombado pelo município, ou se já estiver tombado pelo Estado ou pela União;
b) Se inseridos no Inventário do Patrimônio Histórico e Artístico Nacional - IPAC. Nesse caso ele será apenas um dos componentes que colaboraram para a pontuação do IPAC;
c) Através do tombamento de acervos arqueológicos.

Assim, um sítio arqueológico possui o mesmo valor, para fins de pontuação, que um Bem Arquitetônico ou outro tipo de Bem Cultural. Outro problema afigura-se perante essa orientação: o tombamento de sítios arqueológicos ${ }^{54}$. Ora, os sítios arqueológicos já possuem uma proteção legal federal, que poderia ser considerada para fins de pontuação. Ademais, a maioria dos tipos de sítios arqueológicos pode ser escavada parcial ou integralmente, levando ao desaparecimento do sítio, em troca das informações produzidas e do acervo gerado.

Tal situação, muito comum em empreendimentos potencialmente lesivos ao meioambiente, obrigaria ao constante destombamento dos sítios por parte dos respectivos municípios. A lei também não deixa claro se um acervo gerado por escavação arqueológica terá pontuação menor, maior ou igual àquela recebida pelo sítio tombado.

Acreditamos que seria mais adequado pontuar os sítios cadastrados no IPHAN, já que todos os sítios identificados devem ser cadastrados nesse órgão e tem por natureza uma proteção legal. Ademais, os sítios arqueológicos deveriam ter uma pontuação diferenciada, dada a importância de sua proteção e pelo fato de existirem sítios de grande porte, com vários componentes e que não podem receber a mesma pontuação de uma casa tombada, por exemplo.

\footnotetext{
${ }^{54}$ Deliberação Normativa do Conselho Curador do IEPHA/MG para o Exercício de 2003
} Parágrafo primeiro - Os sítios arqueológicos pré-históricos e históricos deverão ser tombados para serem pontuados como atributo conjunto paisagístico ou bens imóveis, e deverão atender às exigências feitas para os bens imóveis, constantes do Quadro I.

Parágrafo segundo - No caso de sítios arqueológicos tombados abertos à visitação ou ao turismo, deverá ser realizado um Plano de Gestão aprovado pelo IPHAN, condição para serem considerados para efeito de pontuação da Lei 13.803/00. 
Apesar de existirem cerca de mil sítios cadastrados no IPHAN em MG, até o momento o IEPHA não se deparou com a situação de um salvamento arqueológico em um sítio tombado, o que provavelmente levará os técnicos do IEPHA a repensarem os critérios de pontuação dos sítios.

A partir da criação da Lei Estadual no $13.803 / 00$ e da política do IEPHA um grande número de municípios vêm implantando políticas municipais de Patrimônio Cultural. Muitos municípios inscritos nesse programa apenas estão interessados em aumentar a arrecadação do ICMS, o que demonstra os vários pedidos de tombamento de bens imóveis que não continham os valores mínimos necessários para receberem a proteção legal do tombamento. Entretanto, tal mudança apenas se dará a médio e longo prazo. Enquanto isso, o tombamento de alguns bens, o inventário do patrimônio, ações educativas, etc. colaboram para assegurar a preservação de nosso legado histórico e cultural. Se políticas como essa fossem adotadas pelos demais Estados da Federação, certamente teríamos uma realidade bastante diferente da atual.

Em estados como São Paulo, por exemplo, o diálogo com o Poder Público Municipal dá-se sempre através da tentativa de convencimento para a preservação da história, das exigências legais, do possível aproveitamento turístico e educacional do patrimônio, etc. Mas, de concreto e de imediato, pouco podemos oferecer aos agentes públicos das Prefeituras. A situação seria diferente se estivesse disponível o aumento no repasse da arrecadação do ICMS.

Outro destaque do estado de Minas Gerais é o Decreto Estadual $n^{\circ} 42.505$, de 15 de abril de 2002, que institui as formas de Registros de Bens Culturais de Natureza Imaterial ou Intangível como patrimônio cultural. O artigo 10 cria, no âmbito da Secretaria de Estado da Cultura, o "Programa Estadual do Patrimônio Imaterial", visando à implementação de política específica de inventário, referenciamento e valorização desse patrimônio. 
O Decreto estabelece Livros de Registros dos Saberes; das Celebrações; das Formas de Expressão, e dos Lugares, deixando aberta a possibilidade da criação de outros livros de registros não previstos no Decreto (Artigo $1^{\circ}, \S 2^{\circ}$ ). ${ }^{55}$

\subsection{O papel da União}

A União tem competência comum com os demais entes federativos para proteger os bens culturais.

Art. 23. É competência comum da União, dos Estados, do Distrito Federal e dos Municípios:

III - proteger os documentos, as obras e outros bens de valor histórico, artístico e cultural, os monumentos, as paisagens naturais notáveis e os sítios arqueológicos; IV - impedir a evasão, a destruição e a descaracterização de obras de arte e de outros bens de valor histórico, artístico ou cultural;

Também possui competência concorrente aos Estados e ao Distrito Federal para legislar sobre a proteção do patrimônio cultural.

Art. 24. Compete à União, aos Estados e ao Distrito Federal legislar concorrentemente sobre:

$(\ldots)$

VII - proteção ao patrimônio histórico, cultural, artístico, turístico e paisagístico;

55 Art. $1^{\circ}$ - Ficam instituídas as formas de registro de bens culturais de natureza imaterial que constituem o patrimônio cultural de Minas Gerais.

$\$ 1^{\circ}$ - O registro dos bens culturais de natureza imaterial que constituem patrimônio cultural mineiro será efetuado em quatro livros, a saber:

I - Livro de Registro dos Saberes, onde serão inscritos conhecimentos e modos de fazer enraizados no cotidiano das comunidades;

II - Livro de Registro das Celebrações, onde serão inscritos rituais e festas que marcam a vivência coletiva do trabalho, da religiosidade, do entretenimento e de outras práticas da vida social;

III - Livro de Registro das Formas de Expressão, onde serão inscritas manifestações literárias, musicais, plásticas, cênicas e lúdicas;

IV - Livro de Registro dos Lugares, onde serão inscritos mercados, feiras, santuários, praças e demais espaços onde se concentram e se reproduzem práticas culturais coletivas.

§ $2^{\circ}$ - Outros livros de registro poderão ser abertos para a inscrição de bens culturais de natureza imaterial que constituam patrimônio cultural mineiro e não se enquadrem nos livros definidos no parágrafo anterior. 
VIII - responsabilidade por dano ao meio ambiente, ao consumidor, a bens e direitos de valor artístico, estético, histórico, turístico e paisagístico;

(...)

$\S 11^{\circ}$ No âmbito da legislação concorrente, a competência da União limitar-se-á a estabelecer normas gerais.

Além do que está estabelecido na Constituição Federal, há o Decreto 25, de 1937, que organiza a proteção do patrimônio histórico e artístico nacional.

Existem outras normas jurídicas, conforme descritas a seguir:

- Lei Federal 3924/61 que trata da proteção do patrimônio arqueológico. Ela utiliza muitos termos imprecisos ou incorretos, e são limitados até mesmo em função do que se conhecia sobre arqueologia no Brasil na década de 1960. Assim, há referências a "monumentos arqueológicos ou pré-históricos" e "jazidas arqueológicas ou pré-históricas", considerando também todos os objetos neles contidos ou sob a guarda do Poder Público. O próprio termo "jazida" é mais utilizado para se referir a um depósito natural de substâncias como minerais ou combustíveis para exploração comercial. Mas a lei também exemplifica alguns tipos de sítios incluídos nos termos utilizados, onde foram contemplados cemitérios indígenas, sambaquis, abrigos sob rocha, sítios cerâmicos, líticos ou com pinturas rupestres e outros. ${ }^{56}$ Este é o principal instrumento jurídico para a proteção do patrimônio arqueológico.

${ }^{56}$ Lei 3924/61. Art. $1^{0}$ - "Os monumentos arqueológicos ou pré-históricos de qualquer natureza existentes no território nacional e todos os elementos que neles se encontram ficam sob a guarda e proteção do Poder Público, de acordo com o que estabelece o Art. 180 da Constituição Federal.

(...) Art. $2^{\circ}$ - Consideram-se monumentos arqueológicos ou pré-históricos:

a) as jazidas de qualquer natureza, origem ou finalidade, que representem testemunhos da cultura dos paleoameríndios do Brasil, tais como sambaquis, montes artificiais ou tesos, poços sepulcrais, jazigos, aterrados, estearias e quaisquer outras não especificadas aqui, mas de significado idêntico, a juízo da autoridade competente;

b) os sítios nos quais se encontram vestígios positivos de ocupação pelos paleoameríndios, tais como grutas, lapas e abrigos sob rocha;

c) os sítios identificados como cemitérios, sepulturas ou locais de pouso prolongado ou de aldeamento "estações" e "cerâmicos", nos quais se encontram vestígios humanos de interesse arqueológico ou paleoetnográfico;

d) as inscrições rupestres ou locais como sulcos de polimentos de utensílios e outros vestígios de atividade de paleoameríndios". 
Faz-se necessária uma revisão desta lei, principalmente dos termos e conceitos. Entretanto, tal revisão seria extremamente arriscada em termos políticos, uma vez que, aberta para discussão e alterações, a pressão de grupos econômicos ligados à construção civil, imóveis e meio-ambiente poderia resultar na perda de conquistas trazidas pela 3924 .

- Portaria IPHAN 07/88 determina as normas e procedimentos para pesquisa e escavações arqueológicas, bem como a guarda de artefatos coletados. É através desta Portaria que se estabelece a relação arqueólogo - IPHAN, em termos de pesquisa. Embora importante, a Portaria ainda carrega uma carga de exigências burocráticas muito grande e desnecessária. Um processo para Diagnóstico ou pesquisa arqueológica numa área onde haverá um empreendimento, por exemplo, pode levar até 10 meses para ser concluído, incluindo-se apresentação do projeto, publicação da Portaria do IPHAN no Diário Oficial da União, pesquisa, aprovação do Relatório e emissão de Parecer Técnico. Isto considerando que não seja necessário salvamento arqueológico de um sítio identificado, ou monitoramento arqueológico das obras, o que dá origem a um novo processo.

O credenciamento de arqueólogos pelo IPHAN e o estabelecimento de um padrão mínimo necessário para os diferentes tipos de pesquisa, em substituição à análise prévia do projeto pelo IPHAN e publicação da Portaria no DOU, seriam fundamentais para tornar os processos mais rápidos, a área mais ágil e eficiente, deixando mais tempo aos técnicos do IPHAN para o gerenciamento do patrimônio do país. Nesse sentido, propostas similares, com inscrição On-Line dos projetos no IPHAN, já foram sinalizadas por técnicos do órgão no último encontro da Sociedade de Arqueologia Brasileira (2003).

- Portaria IPHAN 230/02 é a norma mais importante desde a Lei 3924 de 1961, que passou a proteger os sítios arqueológicos. A Portaria 230 compatibilizou a preservação do patrimônio arqueológico com os Licenciamentos Ambientais em empreendimentos potencialmente lesivos ao meio ambiente. Assim, obriga os responsáveis pelos empreendimentos à realização do levantamento arqueológico e ao resgate de eventuais sítios arqueológicos encontrados e que seriam destruídos pelas obras de empreendimentos potencialmente lesivos ao 
Patrimônio Cultural e ao Meio Ambiente, tais como: hidrelétricas, oleodutos, estradas, alguns loteamentos, sistemas de água e esgotos, e outros casos estabelecidos na Resolução do Conselho Nacional do Meio Ambiente CONAMA, de 1988.

A Portaria define os procedimentos do diagnóstico arqueológico em cada fase do licenciamento ambiental, bem como para o resgate de sítios encontrados. Inovou ao definir que a guarda destes vestígios arqueológicos "deverá ser garantida pelo empreendedor, seja na modernização, na ampliação, no fortalecimento de unidades existentes, ou mesmo na construção de unidades museológicas específicas para o caso". Até então, a manutenção da maioria dos acervos gerados pelas pesquisas arqueológicas ficava sob a responsabilidade de instituições públicas, gerando gastos para sua conservação, seu acondicionamento, comunicação, etc. Outro importante aspecto foi a obrigatoriedade da realização de programas de Educação Patrimonial, "os quais deverão estar previstos nos contratos entre os empreendedores e os arqueólogos responsáveis pelos estudos, tanto em termos de orçamento quanto de cronograma".

Esta Portaria revolucionou o meio arqueológico, seja em termos de proteção, pois trabalha com a idéia de medidas preventivas, como na sua adequação dos Estudos de Licenciamentos Ambientais. Mesmo em termos profissionais, ela propiciou uma enorme demanda por arqueólogos que, até então, pouco atuavam nesse setor.

- Portaria IPHAN 28/2003: Determina que os reservatórios de empreendimentos hidrelétricos de qualquer tamanho ou dimensão dentro do território nacional deverão doravante na solicitação da renovação da licença ambiental de operação prever a execução de projetos de levantamento, prospecção, resgate e salvamento arqueológico da faixa de depleção. O IPHAN considerou as enormes perdas do patrimônio arqueológico ocorridas com a implantação de Usinas Hidrelétricas no Brasil; que apenas recentemente os referidos empreendimentos estão sendo objeto de estudos de impacto ambiental, e mais recentemente ainda estão a incorporar a variável destinada à proteção do Patrimônio Cultural 
Arqueológico. Também considerou a necessidade de reparar, minimizar e mitigar os impactos negativos potencialmente causados pela implantação dos referidos empreendimentos.

- Portaria 108/DPC - 2003: Esta norma é do Ministério da Defesa, da DiretoriaGeral de Navegação, Diretoria de Portos e Costas do Comando da Marinha. Aprova as Normas da Autoridade Marítima para Pesquisa, Exploração, Remoção e Demolição de Coisas e Bens Afundados, Submersos, Encalhados e Perdidos NORMAM-10/DPC. Estabelece normas e procedimentos para autorização de pesquisa, remoção, demolição ou exploração de bens naufragados pertencentes a terceiros ou à União, e do turismo subaquático em sítios arqueológicos incorporados ao domínio da União.

- Instrução Normativa № 1, de 25 /2003: Dispõe sobre a acessibilidade aos bens culturais imóveis acautelados em nível federal. Estabelece diretrizes, critérios e recomendações para a promoção das devidas condições de acessibilidade aos bens culturais imóveis, a fim de equiparar as oportunidades de fruição destes bens pelo conjunto da sociedade, em especial pelas pessoas portadoras de deficiência ou com mobilidade reduzida. 
PARTE III

Ações e Projetos de Municípios

NA GESTÃo do PatRIMÔNıO 


\section{Parte III}

\section{AÇÕES E PROJETOS DE MUNICÍPIOS NA GESTÃO DO PATRIMÔNIO}

\section{1 - BELÉM I PA}

A cidade de Belém possui uma lei municipal de proteção do Patrimônio Cultural desde 1994. A Lei $n^{\circ}$ 7.709, de 18 de maio de 1994, "dispõe sobre a preservação e proteção do Patrimônio Histórico, Artístico, Ambiental e Cultural do Município de Belém e dá outras providências".

A referida lei confere à Fundação Cultural do Município de Belém a competência da implementação da política de proteção e valorização do Patrimônio Histórico Cultural.

Permite-se, através dessa lei, o tombamento municipal de qualquer Bem móvel ou imóvel que possua as características contempladas na lei. No caso de tombamento, o ato é divulgado no Diário Oficial do Município, em um jornal de grande circulação do Município, e será inscrito no respectivo Livro de Tombo.

A Fundação Cultural do Município de Belém possui quatro Livros de Tombo ou de Registros de Bens Culturais, nos quais são inscritos os bens a que se refere o disposto no art. $1^{\circ}$ da Lei, a saber:

1 - Livro de Tombo de Bens Naturais - incluem-se paisagens, espaços ecológicos, recursos hídricos, monumentos e sítios, reservas naturais, parques e reservas municipais;

2 - Livro de Tombo de bens Arqueológicos e Antropológicos;

3 - Livro de Tombo de Bens Imóveis de valor histórico, arquitetônico e urbanístico, quer urbanos, rurais e paisagístico, como: obras; edifícios, conjuntos e sítios urbanos ou rurais;

4 - Livro de Tombo de bens móveis e integrados de valor histórico, artístico, folclórico, iconográfico, toponímico, etnográfico, incluindo-se acervos de 
bibliotecas, arquivos, museus, coleções, objetos e documentos de propriedade pública e privada.

Os Bens imóveis tombados em nível municipal são classificados em cinco categorias:

1. Preservação Arquitetônica Integral: intervenção destinada à preservação das características arquitetônicas, artísticas e decorativas internas e externas do imóvel em questão;

2. Preservação Arquitetônica Parcial: intervenção destinada à conservação das características arquitetônicas, artísticas e decorativas externas do imóvel em questão;

3. Imóveis de Reconstituição Arquitetônica: intervenção destinada à recuperação das características arquitetônicas, artísticas e decorativas que anteriormente compunham a fachada e cobertura na época da construção do imóvel em questão;

4. Imóveis de Acompanhamento: intervenção destinada à conservação da fachada externa e da cobertura do imóvel que embora não tenha características arquitetônicas de interesse à preservação não interfere substancialmente na paisagem devendo manter-se a harmonia volumétrica;

5. Imóveis de Renovação: intervenção destinada à construção de nova edificação e ou substituição de uma edificação que não tem interesse à preservação.

Os imóveis classificados nas categorias acima ficam isentos de taxa para licenciamento de obra. O município também incentiva a conservação dos imóveis, oferecendo isenção do Imposto sobre a Propriedade Predial e Territorial Urbano (IPTU) para os imóveis classificados no exemplo anterior, dos itens 01 a 04, desde que situados fora dos limites do Centro Histórico de Belém, conforme os índices abaixo: 
- $100 \%$ para os bens tombados e íntegros arquitetonicamente (bens imóveis classificados na categoria de preservação arquitetônica integral);

- 75\% para bens imóveis parcialmente modificados (bens imóveis classificados na categoria de preservação arquitetônica parcial e os de reconstituição arquitetônica);

- $10 \%$ para os classificados como de acompanhamento.

A Lei também contempla o patrimônio ambiental, protegendo, a priori, as mangueiras e sumaumeiras (Mangífera índice e Ceiba Sumahuma respectivamente) existentes nos logradouros públicos do Município de Belém, além de proteger as orlas marítimas e ribeirinhas.

Para analisar os pedidos e processos de tombamento, existe um Conselho de Patrimônio Cultural Municipal. 


\subsection{BELO HORIZONTE I MG}

O município de Belo Horizonte possui lei de proteção do patrimônio cultural desde 1984. A Lei 3802 protege o patrimônio, considerado de forma abrangente. Estabelece os seguintes Livros de Tombo em seu artigo $4^{\circ}$ :

I - no Livro do Tombo Arqueológico, Etnográfico e Paisagístico, as coisas pertencentes às categorias de arte arqueológica, etnográfica, ameríndia e popular, e bem assim as mencionadas no $\S 2^{\circ}$ do citado Art. $1^{\circ}$;

II - no Livro do Tombo Histórico, as coisas de interesse histórico e as obras de arte histórica;

III - no Livro do Tombo das Belas-artes, as coisas de arte erudita nacional ou estrangeira;

IV - no Livro do Tombo das Artes Aplicadas, as obras que se incluírem na categoria das artes aplicadas, nacionais ou estrangeiras.

A lei também criou o Conselho Deliberativo do Patrimônio Cultural do Município, formado por representantes do Poder Público Municipal, Poder Legislativo, Sociedade Civil, Universidades e órgãos de preservação federal e estadual.

Uma das particularidades dessa Lei é a determinação a todos os negociantes de antiguidades, de obras de arte de qualquer natureza, de manuscritos e livros antigos ou raros, serem obrigados a um registro especial junto ao Conselho Deliberativo do Patrimônio Cultural do Município, cumprindo-Ihes apresentar semestralmente a relação completa das coisas históricas e artísticas que possuírem. 


\subsection{BLUMENAU - SC}

O Município de Blumenau possui lei de tombamento e Conselho de Patrimônio. Voltadas quase que exclusivamente ao patrimônio edificado, e se procura preservar, principalmente a arquitetura enxaimel.

O município, de origem germânica, valoriza muito seus pioneiros e, em especial, o Dr. Blumenau, fundador da cidade. Embora o município invista em várias áreas na preservação do patrimônio, técnicos do setor afirmaram que não existem sítios arqueológicos no município, e por isso o poder público nunca se preocupou com essa área. Isto é de se entranhar, pois a cidade é cortada por um importante rio, o Itajaí-Açu.

Os livros didáticos sobre a história da cidade fazem apenas vaga menção sobre contatos entre indígenas Botocudos e os colonizadores alemães. Os textos apresentam o fato como sem importância e esporádico, na realidade até harmonioso.

O livro didático Estudos Sociais - 3a Série, editado pela Secretaria de Educação e Cultura da Prefeitura Municipal de Blumenau ${ }^{57}$, fornece as seguintes informações:

"Os primeiros moradores da região do Vale do Itajaí eram os índios, também conhecidos como bugres (...).

(...) Não se preocupavam em colonizar as terras. Por este motivo, toda a região estava para ser colonizada".

Já um pequeno livro elaborado na forma de quadrinhos, faz uma única menção aos indígenas na região, de forma sintomática:

\footnotetext{
${ }^{57}$ Prefeitura Municipal de Blumenau. Estudos Sociais - $3^{a}$ Série. Blumenau: Secretaria Municipal de Educação e Cultura, 1995, p. 19 - 21.
} 


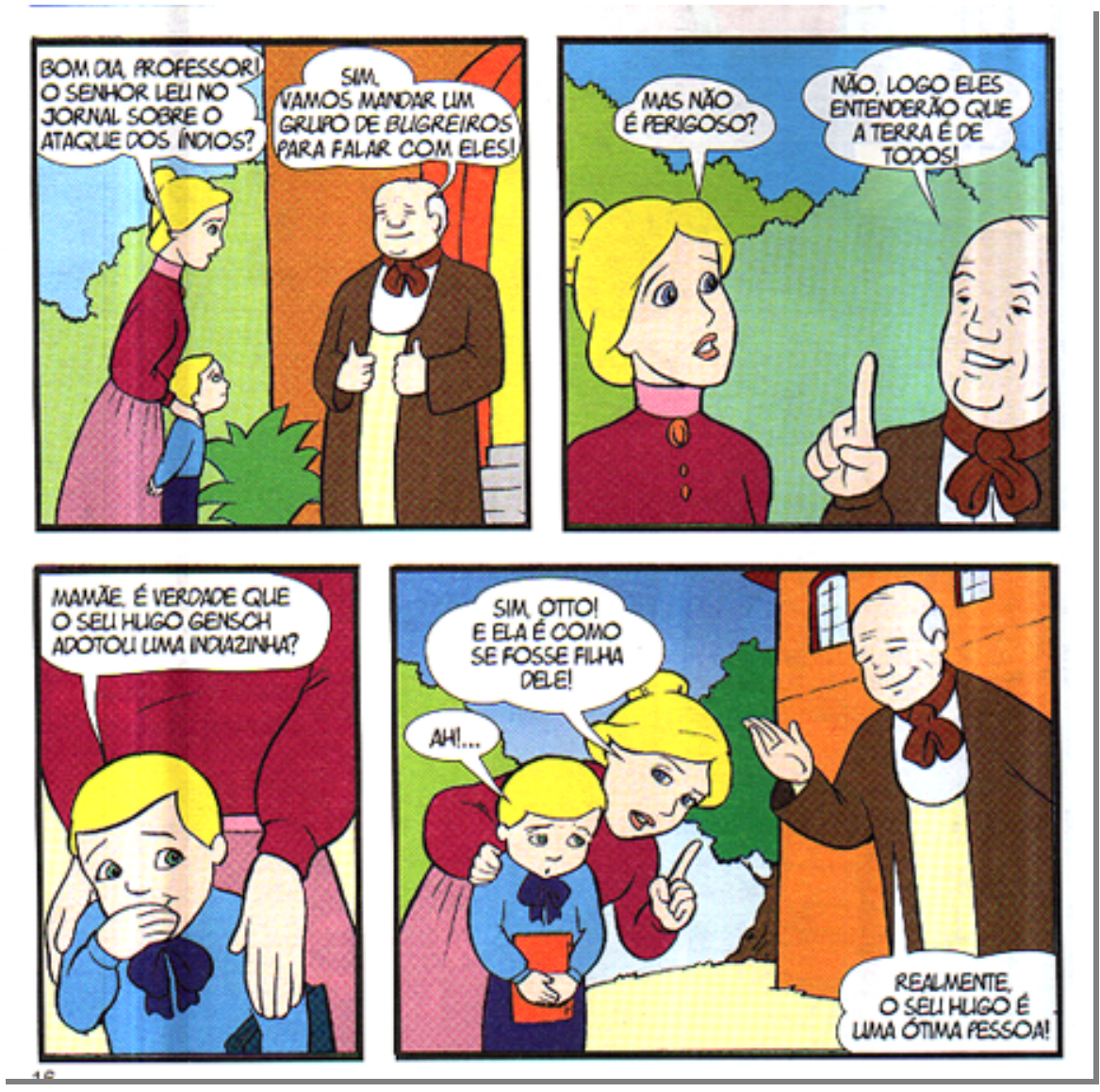

Fig. 01

Este livro ${ }^{58}$ apresenta a História de Blumenau de forma pacífica e harmônica. Contudo, os documentos analisados no Arquivo Histórico de Blumenau apontam para outra interpretação. No arquivo há um "Fundo Indígena", contendo documentos de relatos, incidentes, etc, com índios da região. E, é claro, o contato, não foi pacífico e harmonioso. Houve extermínios em massa, expedições de "bugreiros", etc. O trecho acima selecionado, do livro em quadrinhos, revela um ataque de indígenas e o envio de Bugreiros para "falar com eles". Ora, as tropas de bugreiros eram compostas de 08 a 15 caboclos pagos para afugentar ou, mais comumente, exterminar os indígenas. Como prova do trabalho realizado, podiam trazer um dos indígenas do grupo que os bugreiros haviam enfrentado. Foi o que aconteceu em 1905, quando uma menina indígena, de nome Korikrã, foi trazida à Blumenau (SANTOS, 1997: 28). Esta foi a criança adotada pelo médico do quadrinho acima. O livro omite este pequeno detalhe. Também não menciona o episódio ocorrido em 1852, durante a construção da casa do Dr. Blumenau. Nessa ocasião, alguns

\footnotetext{
${ }^{58}$ KOVÁCS, Anamaria. A História de Blumenau em Quadrinhos. Blumenau: Maju, 2001.
} 
botocudos aproximaram-se da obra e foram recebidos com tiros e depois perseguidos pela mata até o anoitecer. Pelo menos um indígena foi morto. Vários são os relatos de ataques a grupos indígenas em Blumenau e região.

Essa situação mostra como o tipo de política de patrimônio adotada pode colaborar para sustentar uma interpretação da História, a dos colonizadores. E isto se manifesta, em Blumenau, na preservação da arquitetura Enxaimel, na constituição do Museu da Família Colonial, festas, etc. e no ocultamento, consciente ou inconsciente, da História dos indígenas da região. Nesse sentido a Arqueologia seria fundamental no resgate desse passado, mostrando as contradições entre a história oficial e as interpretações que poderiam derivar das pesquisas arqueológicas.

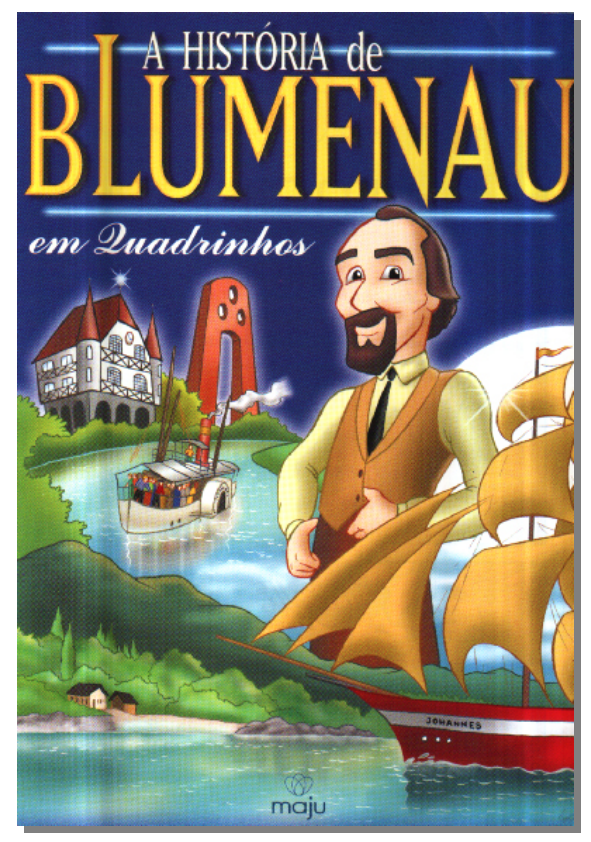

Fig. 02

\section{4 - CAMPINAS - SP}

O município de Campinas possui o Conselho de Defesa do Patrimônio Cultural de Campinas - Condepacc. Tal conselho foi criado pelo Decreto $\mathrm{n}^{\circ} 9546$ de 30 de junho de 1988 e está subordinado a Secretaria Municipal de Cultura. Possui como órgão de apoio a Coordenadoria de Patrimônio Cultural.

No artigo $1^{\circ}$ da lei de criação do Conselho, considera-se o patrimônio cultural do município, o patrimônio histórico, artístico, estético, arquitetônico, arqueológico, documental e ambiental.

O Conselho é composto por 23 membros, sendo 06 da Administração Municipal, 01 da Câmara Municipal, 03 de conselhos municipais, 01 do Condephaat, 02 de universidades e 10 de associações civis. 
Já a Decreto no 9584 de 11 de agosto de 1988, trata do recebimento de pedidos de tombamento e intervenções em bens tombados. Esse Decreto é complementado por outro, o de n 9585/88, que dispõe sobre a tramitação de processos de tombamento.

\section{5 - GUARULHOS - SP}

A cidade de Guarulhos possui uma lei de tombamento municipal de 1985, que também cria o Conselho Consultivo Municipal de Patrimônio Histórico. Este conselho foi alterado pela Lei 3618/90, e é composto por 14 membros, sendo 07 do Poder Executivo, 01 do Legislativo e 04 de Universidades situadas no Município. 


\section{6 - FLORIANÓPOLIS - SC}

As ações de patrimônio em Florianópolis foram iniciadas através da criação do Serviço do Patrimônio Histórico, Artístico e Natural do Município - SEPHAN, que atua principalmente na proteção do patrimônio edificado da cidade. O SEPHAN conta com a colaboração da COTESPHAN (Comissão Técnica do SEPHAN), que, através da representação de diversas entidades indicadas, atua na assessoria sobre as questões pertinentes ao patrimônio cultural.

Em 1979, o SEPHAN foi transferido para o IPUF (Instituto de Planejamento Urbano de Florianópolis), integrando a preservação ao planejamento urbano da cidade.

Florianópolis apresenta uma situação atípica em comparação com outras cidades que assumiram o gerenciamento do patrimônio local. Embora ela possua um órgão de patrimônio, áreas de proteção e bens tombados, não há legislação específica de tombamento. A proteção é feita através de decretos municipais de tombamento e da utilização da lei de uso do solo e do Plano Diretor. Assim, temos os seguintes exemplos:

- Núcleos urbanos protegidos: Ribeirão da Ilha, Santo Antônio de Lisboa e Lagoa da Conceição. Preservados pelo Plano Diretor dos Balneários Lei Municipal $n^{\circ}$ 2.193/85. Posteriormente, leis complementares ampliaram os locais protegidos:

Área Central - Lei Complementar 001/97

$>$ Canasvieiras - Lei Municipal no 2.193/85

$>$ Costa da Lagoa - Lei Municipal no 2.193/85

$>$ Lagoa da Conceição - Lei Municipal no 2.193/85

$>$ Ribeirão da llha - Lei Municipal no 2.193/85

$>$ Santo Antônio de Lisboa - Lei Municipal no 2.193/85

> São José da Ponta Grossa - Lei Municipal no 2.193/85

- Tombamento de dez conjuntos urbanos no centro da cidade: Decreto Municipal $n^{\circ}$ 270/86, de 30 de dezembro de 1986. 
- Através do Decreto Municipal no 521/89, de 21 de dezembro de 1989, todos os prédios integrantes destes conjuntos históricos foram classificados, de acordo com sua importância histórico/arquitetônica, em três categorias distintas:

"P1 - são aqueles imóveis que, pela sua monumentalidade e valor excepcional, são totalmente preservados, ou seja, tanto no seu interior como no seu exterior;

P2 - são aqueles imóveis que fazem parte da imagem urbana da cidade e que não podem ser demolidos, devendo ser preservada sua volumetria externa, ou seja, fachadas e cobertura. São admitidas reformas internas, desde que não interfiram com o exterior da edificação;

P3 - constitui-se em unidades de acompanhamento dentro das áreas tombadas, sendo importantes para a harmonia do conjunto. Poderão ser demolidas, mas a reedificação está sujeita a restrições que evitem a descaracterização do conjunto no qual está localizado, ou do qual é vizinho".

- Além da preservação dos dez conjuntos da área central, foram realizados vários tombamentos individuais, através de decretos municipais;

- Tombamento de parte da malha viária central, identificada como elemento estruturador de todo o conjunto, através do Decreto Municipal n. ${ }^{\circ}$ 190/90, objetivando preservar parte da estrutura urbana colonial de Florianópolis, em uma área que foi objeto de generalizada substituição da arquitetura definidora do conjunto original;

- O Plano Diretor do Distrito Sede (Lei Complementar nº01/97) também definiu Áreas de Preservação Cultural (APC), objetivando o resgate da identidade urbana pela manutenção de conjuntos ou edificações de arquitetura relevante. 


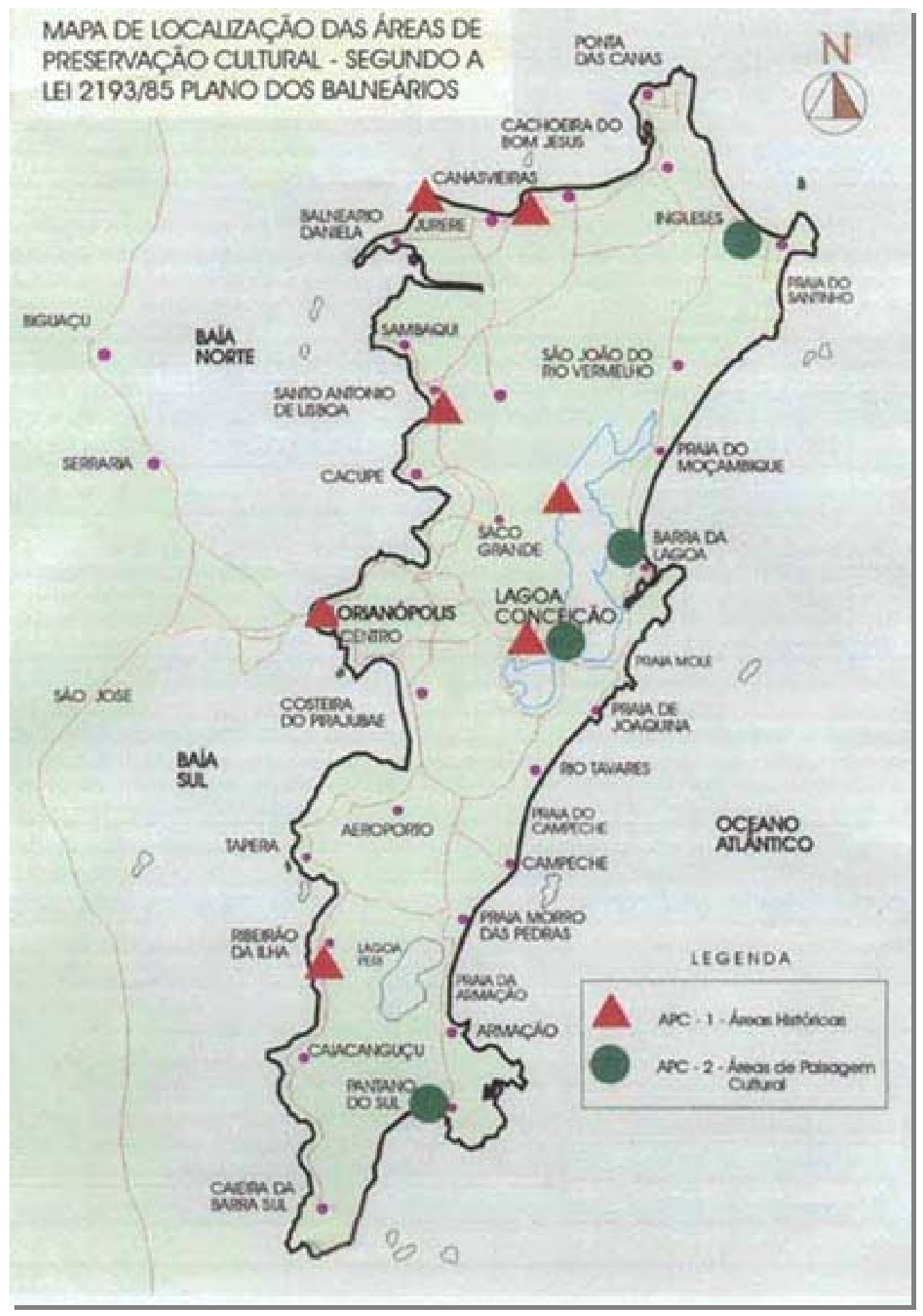

Fig. 03: Mapa elaborado pelo SPHAN/IPUF.Prefeitura Municipal de Florianópolis

Com relação ao patrimônio arqueológico, o Poder Público Municipal exclui-se de qualquer participação e responsabilidade no seu gerenciamento, encaminhando todos os casos ao IPHAN. 
De acordo com levantamento efetuado pelo IPHAN/SC, existem aproximadamente 130 sítios arqueológicos no município.

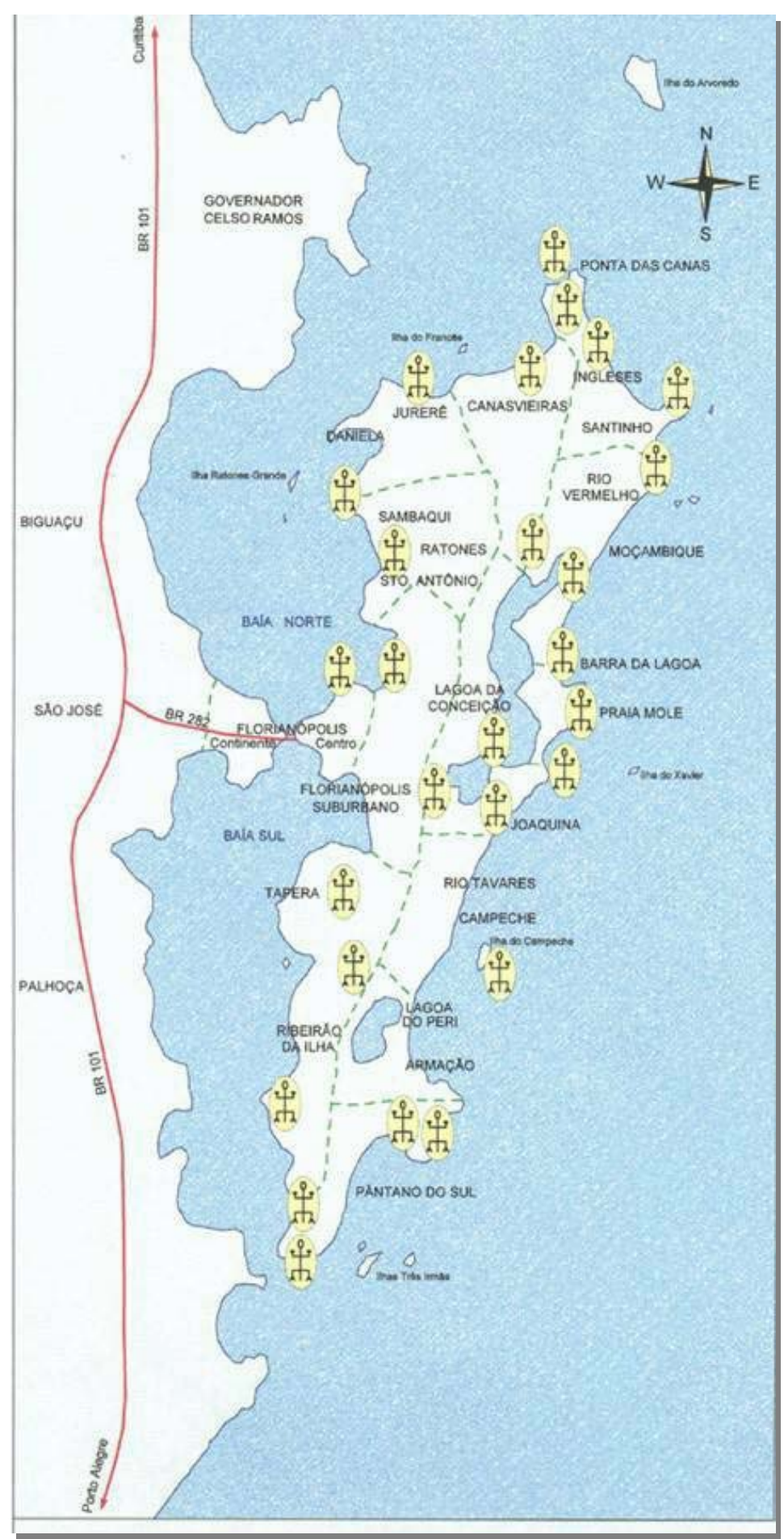

Fig. 04: Mapa elaborado pelo SPHAN/IPUF - Prefeitura Municipal de Florianópolis, com base em dados do IPHAN 
Dentre os programas desenvolvidos pelo SEPHANIPUF, destacamos o "Projeto Renovar", que visa normatizar, orientar e sensibilizar a comunidade para a preservação do patrimônio histórico edificado. Tem como meta principal a recuperação global dos conjuntos históricos da área central de Florianópolis. A campanha, intitulada "Projeto Renovar - nossa história viva e a cores", lançada inicialmente em 1994, contou com o patrocínio de diversas entidades, e possibilitou a elaboração de um manual de recuperação de edificações, que foi entregue a todos os proprietários

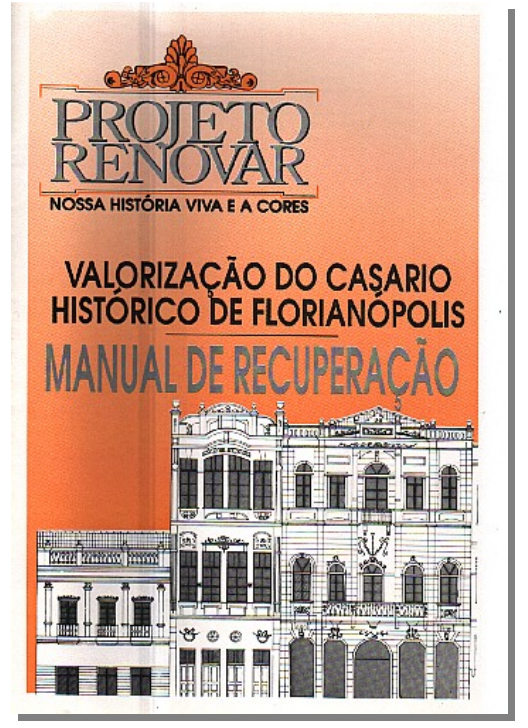

Fig. 05 de imóveis tombados. Essa cartilha oferece: orientações necessárias para a restauração do bem preservado ou a construção em áreas vizinhas; as normas gerais para a recuperação do bem preservado, de acordo com a sua classificação de tombamento; e as orientações gerais de como executar um restauro ${ }^{59}$.

Sobre os incentivos oferecidos aos proprietários de Bens Tombados, o município concede redução do IPTU (Imposto Predial e Territorial Urbano), visando diminuir aos custos de recuperação do proprietário do imóvel. É concedido aos imóveis tombados individualmente e aqueles partícipes dos conjuntos tombados e inseridos em APC-1 (Área de Preservação Cultural), classificados como P1 e P2.

Para efeitos de redução do IPTU, consideram-se os seguintes aspectos:

- estado de conservação: representando até $60 \%$ do benefício;

- estado da pintura e a comunicação visual: representando 20 \% cada item.

O percentual de redução do valor do imposto é variável em função do estado de conservação da edificação, sendo que as taxas permanecem (coleta de lixo, iluminação pública, etc.).

\footnotetext{
59 INSTITUTO DE PLANEJAMENTO URBANO DE FLORIANÓPOLIS. Valorização do Casario
} Histórico de Florianópolis: Manual de recuperação. Florianópolis: IPUF, 1993. 


\subsection{ILHABELA - SP}

No município vem sendo desenvolvido o Projeto Arqueológico de Ilhabela. Criado em dezembro de 1999, esse projeto foi elaborado com o objetivo de identificar, proteger e promover o patrimônio arqueológico local, através de procedimentos científicos e o desenvolvimento de uma política municipal de gestão desse patrimônio.

O Projeto continua em execução até hoje, sob nossa coordenação, em parceria com a Prefeitura Municipal, através da Secretaria Municipal da Cultura e da Fundação Arte e Cultura de Ilhabela - Fundaci. O projeto também tem o apoio do Parque Estadual de Ilhabela. Foi possível, entre outras ações, identificar setenta sítios arqueológicos, entre sítios concheiros, abrigos sob rocha, sítios ceramistas e sítios de ruínas de fazendas, engenhos, igrejas, habitações e fortificações desde o início da colonização portuguesa até o século XIX.

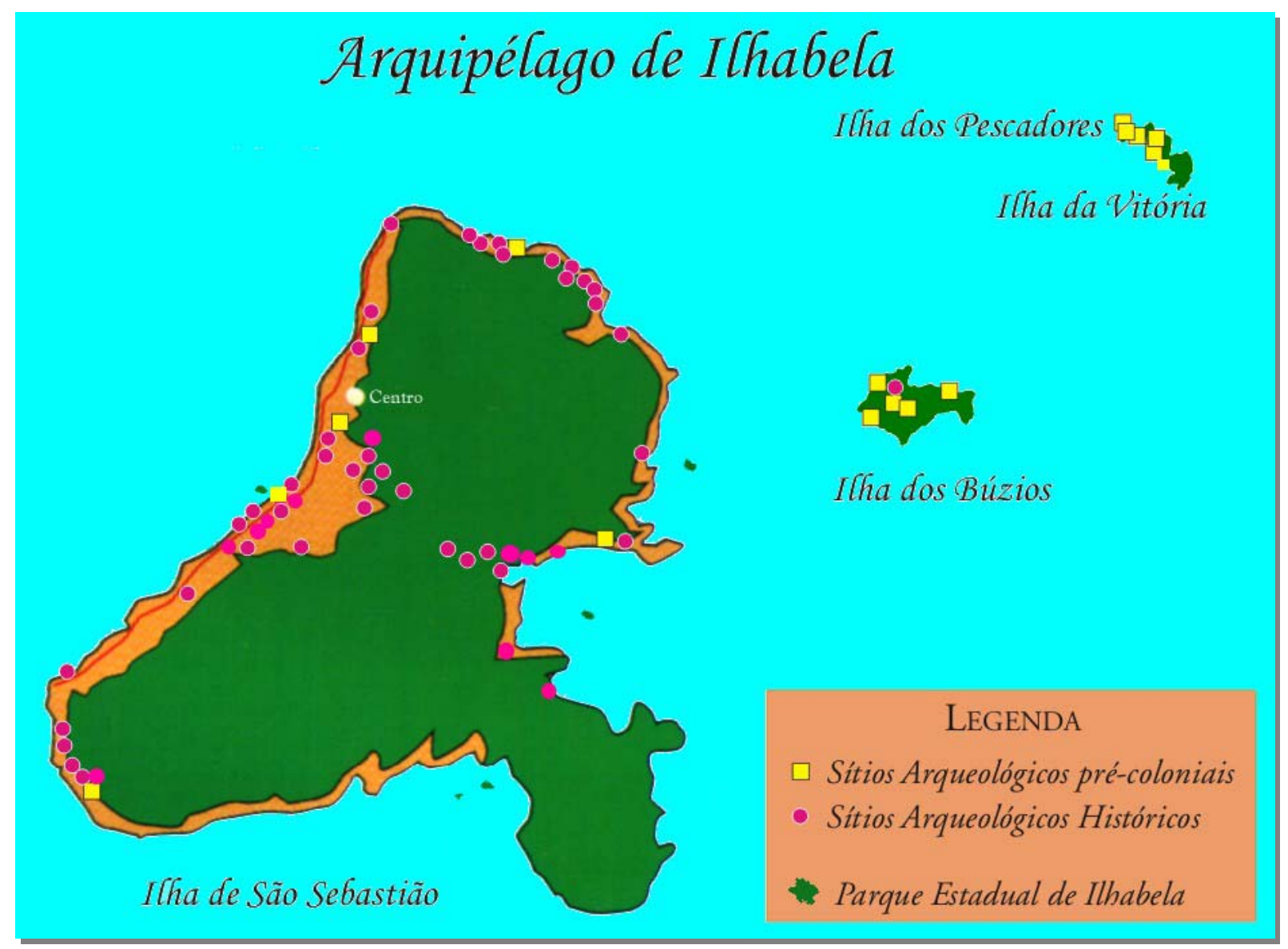

Fig. 06: Fonte: Projeto Arqueológico de Ilhabela, 2005 
Para a viabilização do projeto foi criado um Laboratório de Arqueologia e Reserva Técnica. Já em 2000 foi regulamentado o Instituto Histórico, Geográfico e Arqueológico de Ilhabela, ligado à Secretaria Municipal da Cultura. Este Instituto havia sido criado pela Lei Orgânica do Município (Lei 498/93) e não continha o nome "Arqueológico", acrescentado em 2000, através da Lei 957/00, ocasião em que também foi elaborado o seu Regimento, através do Decreto 2091/00. Os objetivos do Instituto foram definidos no Artigo $3^{\circ}$ de seu Regimento:

Artigo $3^{\circ}$. O Instituto Histórico, Geográfico e Arqueológico de Ilhabela tem por finalidades:

I - Elaborar estudos acerca do patrimônio ambiental, arqueológico, arquitetônico, arquivístico, artístico, histórico, museológico, urbanístico, sejam eles representados por bens de natureza material ou imaterial.

II - Proceder à identificação dos bens culturais do município.

III - Assessorar o Poder Público Municipal no desenvolvimento de políticas municipais de preservação do patrimônio cultural do município.

IV - Proteger e defender os documentos históricos da municipalidade, empresas, sindicatos, partidos políticos e outros que tenham relevância para a história e a memória de Ilhabela.

V - Reunir, manter e disponibilizar à consulta pública acervo arquivístico, museológico, arqueológico e bibliográfico especializado nas áreas afins, em espaço adequado, garantidas as condições satisfatórias para sua conservação e organização, observada a legislação federal pertinente.

VI - Promover o patrimônio cultural do município nas formas estabelecidas no artigo $4^{\circ}$, Parágrafo II, visando garantir o acesso da população à sua história, o aperfeiçoamento da democracia e à construção da cidadania. 
VII - Estimular as manifestações culturais, sejam elas artísticas, folclóricas e o conhecimento e técnicas das comunidades caiçaras tradicionais.

Apesar de seu papel amplo para atuar com o patrimônio cultural local, basicamente apenas as ações na área de Arqueologia se desenvolveram. A falta de estrutura e pessoal limitou a sua atuação, sendo o patrimônio arqueológico privilegiado, principalmente em função da situação de risco em que se encontravam os sítios arqueológicos. Cabe lembrar que apenas $15 \%$ do território do município de Ilhabela (que é um arquipélago) está fora do Parque Estadual. Assim, o ramo imobiliário valoriza cada área edificável, sendo que as poucas áreas livres têm sido disputadas para implantação de condomínios e similares. Ocorre que $68 \%$ dos sítios identificados no município encontram-se em imóveis particulares com projetos para implantação de empreendimentos imobiliários.

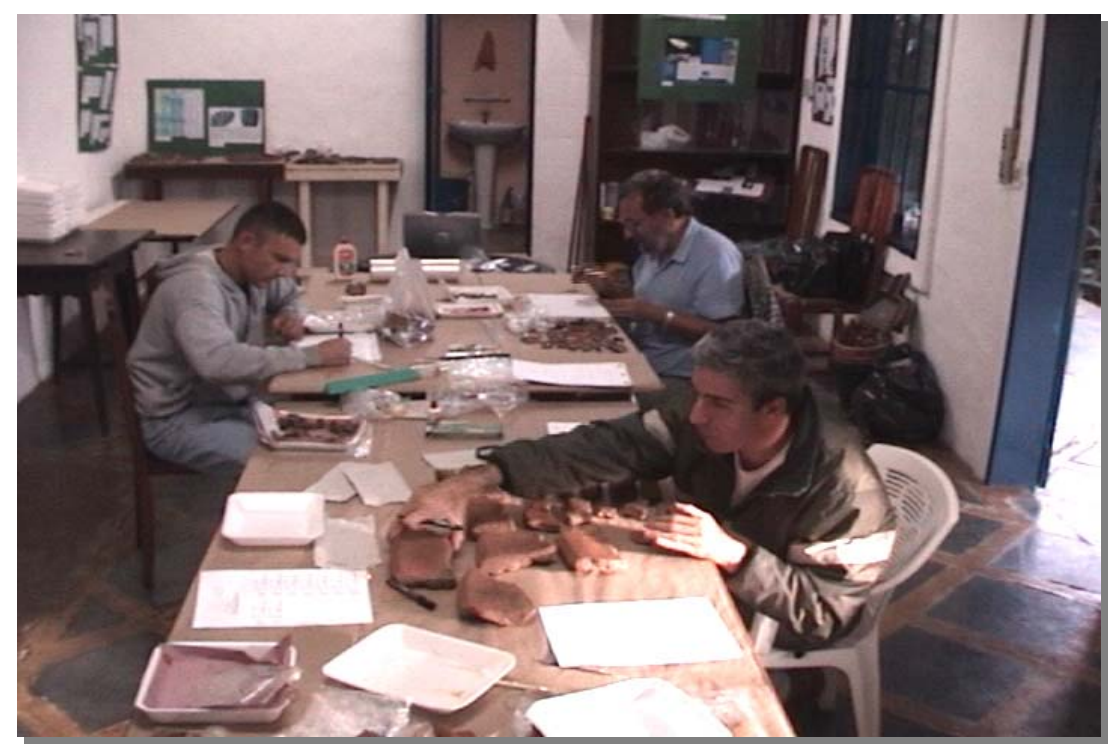

Fig. 07: Trabalho no Laboratório de Arqueologia, 2004. Instituto Histórico, Geográfico e Arqueológico de Ilhabela. Secretaria Municipal da Cultura

Embora o Projeto Arqueológico de llhabela seja desenvolvido em parceria com a Prefeitura Municipal, e o Instituto Histórico, Geográfico e Arqueológico seja um órgão da Secretaria Municipal da Cultura, a atuação das várias secretarias municipais envolvidas na área não caminhou na mesma direção preservacionista, gerando conflitos internos na Administração Municipal. Assim, apesar do inventário dos sítios arqueológicos já existente ser de domínio de todas as Secretarias, da realização de 
palestras e de um curso sobre legislação e proteção do patrimônio arqueológico, que contou com representantes das principais secretarias municipais, é comum a aprovação de empreendimentos imobiliários em imóveis que possuem sítios já identificados, causando grandes problemas e recaindo sobre a Secretaria Municipal da Cultura (através do Projeto Arqueológico e do referido Instituto) o papel de notificar o proprietário desses imóveis e, quando necessário, encaminhar denúncias ao Ministério Público e ao IPHAN.

Dos quatro casos de sítios destruídos total ou parcialmente pelos proprietários, que geraram representação no Ministério Público e denúncia ao IPHAN e Polícia Ambiental ocorridos em 2003, nenhuma atitude concreta foi tomada, sendo que em dois sítios a destruição foi ampliada desde as representações. Situação atípica, visto que todos os casos foram amplamente documentados.
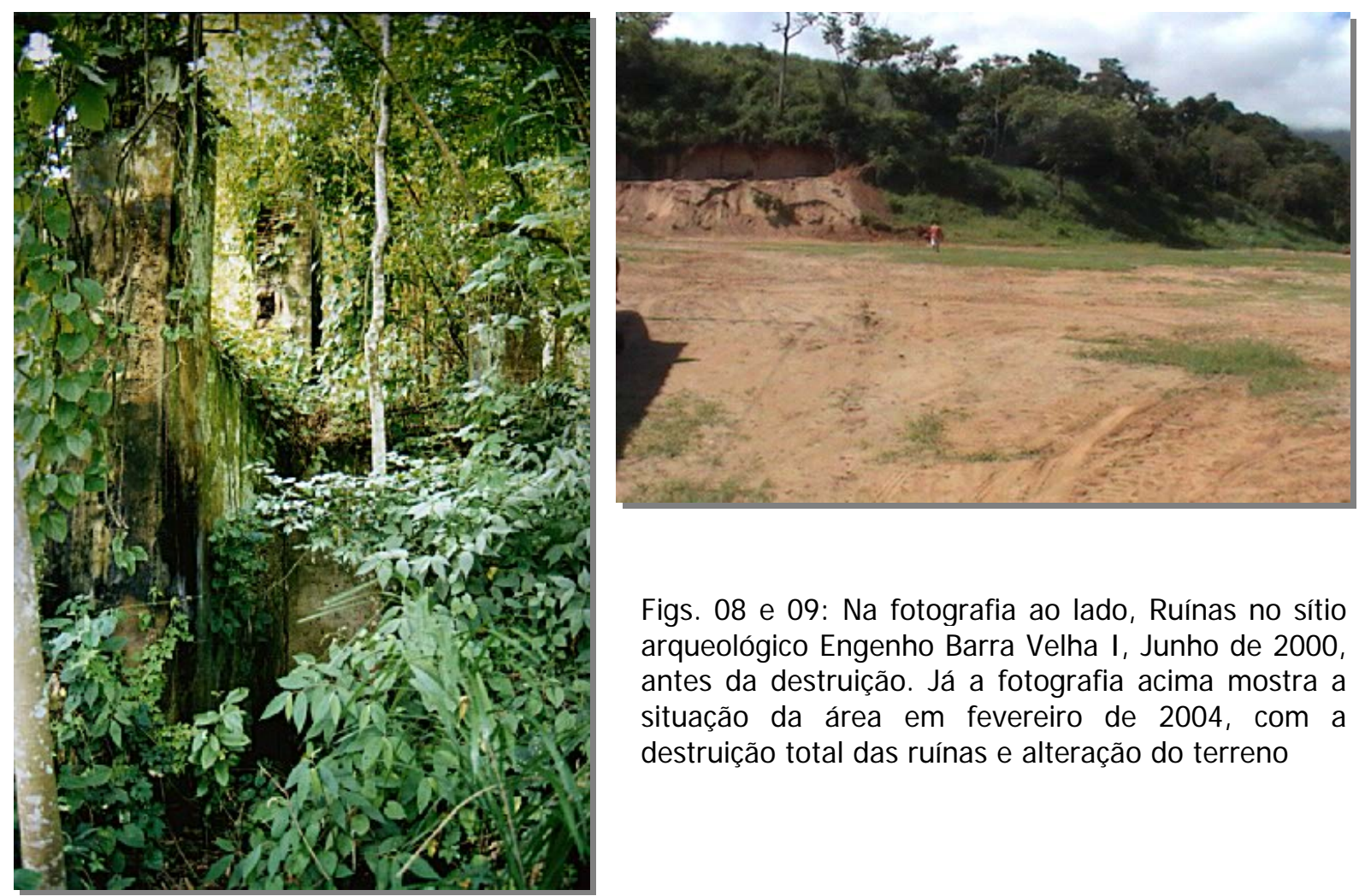

Figs. 08 e 09: Na fotografia ao lado, Ruínas no sítio arqueológico Engenho Barra Velha I, J unho de 2000, antes da destruição. Já a fotografia acima mostra a situação da área em fevereiro de 2004, com a destruição total das ruínas e alteração do terreno 

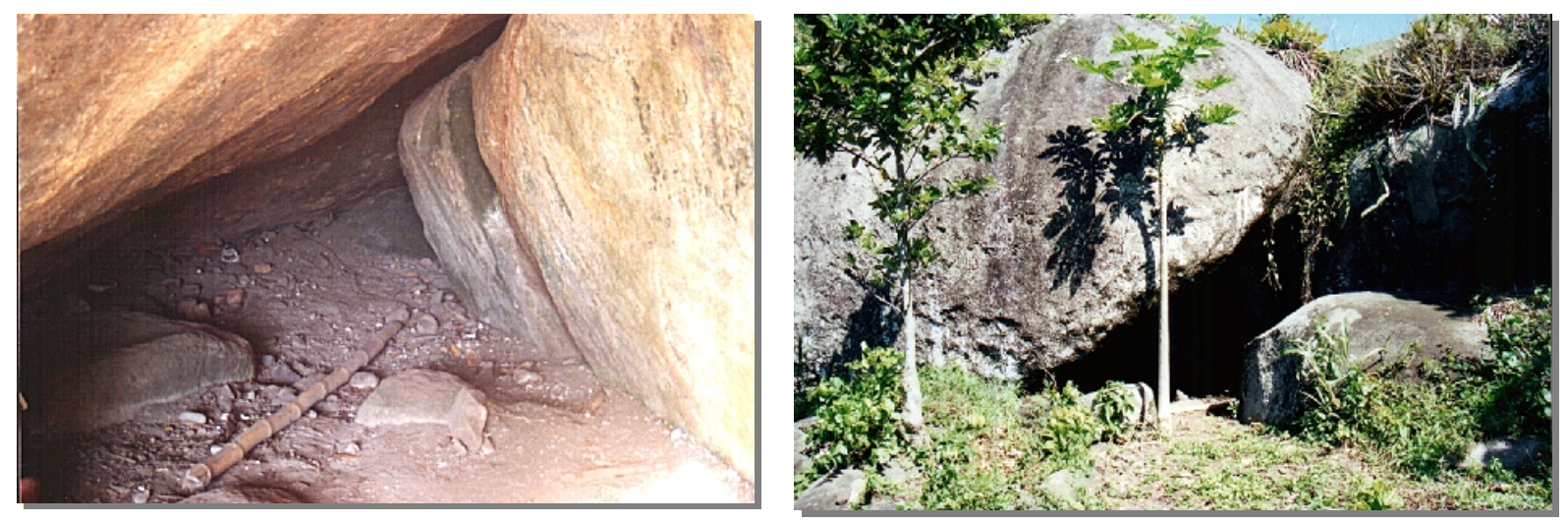

Figs 10 a 13: Nas fotografias acima, de 2000, Sítio Abrigo Furnas I, com seu interior (esquerda), com 0 solo arqueológico original preservado, contendo vários artefatos; e sua parte externa (direita). Já as fotografias abaixo mostram a situação em 2003, com o interior do Abrigo "limpo" e coberto de areia pelo proprietário do imóvel, e a parte externa gramada e com chuveiro na entrada
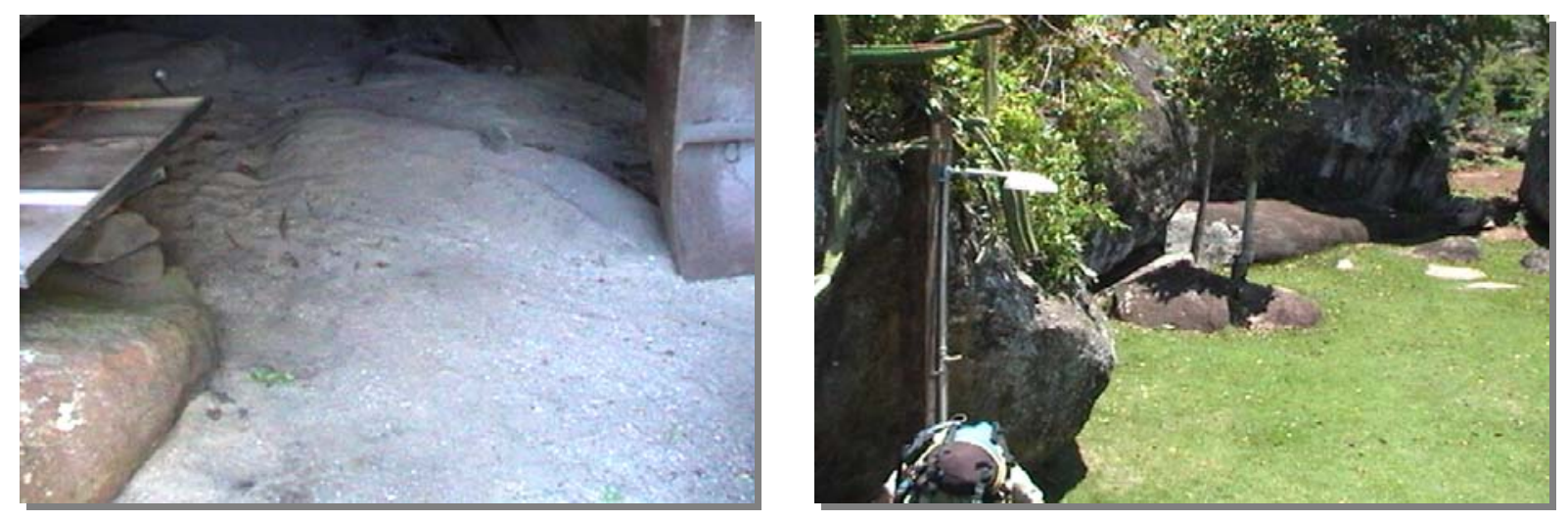

A Secretaria Municipal da Cultura e Fundação Arte e Cultura de Ilhabela adotaram um sistema de notificação e orientação aos proprietários de imóveis que possuam um sítio arqueológico.

Acompanhando a notificação, é encaminhado um folder com orientações ao proprietário do imóvel, reproduzido a seguir: 

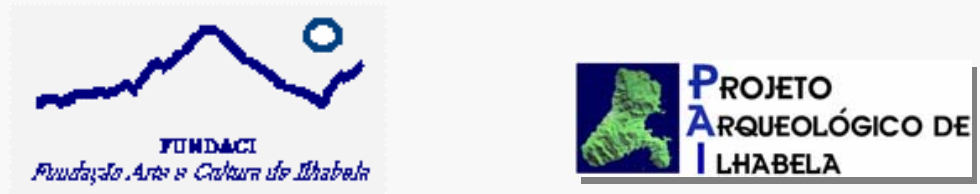

\section{ORIENTAÇÃO AOS PROPRIETÁRIOS DE IMÓVEIS COM SÍTIOS ARQUEOLÓGICOS}

\section{O SÍTIO ARQUEOLÓGICO}

Um sítio arqueológico é qualquer local que o homem do passado tenha deixado vestígios de sua passagem ou estabelecimento. Assim, pode ser o local de uma antiga aldeia, onde encontramos potes de cerâmica, marcas de fogueiras, ossos, vestígios das cabanas e outros. Também pode ser o local de um acampamento temporário de caça, um local onde extraiam e lascavam pedras para a confecção de utensílios como machados e pontas de flecha, uma gruta utilizada para enterrar seus mortos, lápides de pedra com desenhos rupestres, etc. Ainda podem ser o que chamamos de "sítio histórico", que, no Brasil significa locais e construções feitas pelo colonizador europeu, como fortes, engenhos, casas, poços ou até mais recentes. Enfim, é todo local onde o homem alterou o meio ambiente ou deixou vestígio de sua presença.

\section{A RESPONSABILIDADE DO PROPRIETÁRIO DE IMÓVEL COM SÍTIO ARQUEOLÓGICO}

O proprietário ou ocupante do imóvel onde foi identificado um sítio ou artefatos arqueológicos é responsável pela conservação provisória da coisa descoberta, até pronunciamento e deliberação do Instituto do Patrimônio Histórico e Artístico Nacional - IPHAN. Lei 3924/61, Art. 17, Parágrafo Único. 


\section{O DIREITO DE PROPRIEDADE DO IMÓVEL}

O proprietário de um imóvel com um sítio arqueológico continua a ter o direito de propriedade, podendo o Bem ser vendido ou passado normalmente como qualquer outro imóvel. Entretanto, existem restrições de uso. Qualquer nova construção no imóvel ou ação que resulte em movimentação de terra, aterro, etc., deve ter prévia autorização da Prefeitura Municipal de I lhabela e do IPHAN.

\section{CONSTRUÇÕES E OBRAS EM ÁREAS COM SÍTIO ARQUEOLÓGICO}

A presença de um sítio arqueológico geralmente não inviabiliza novos empreendimentos ou obras. Entretanto, é necessária a realização de pesquisa arqueológica no local para resgatar informações sobre o sítio, bem como os artefatos nele contidos. Tal pesquisa deve ser realizada por arqueólogos formados e o projeto deve ser aprovado pelo IPHAN. As normas e quesitos necessários para a elaboração de projetos de Arqueologia estão contidas na Portaria IPHAN 07/88. Após a pesquisa, o resgate e estudo do material coletado, o imóvel pode ser liberado para qualquer obra, a critério do IPHAN. Estruturas imóveis presentes no sítio, como ruínas de construções e abrigos sob rocha, devem ser conservadas. Todos os gastos com os estudos arqueológicos necessários são de responsabilidade do proprietário do imóvel ou do empreendimento que se deseja executar.

\section{Estudos ARqueológicos em Licenciamentos Ambientals}

Atualmente, qualquer área onde ocorrerá um empreendimento ou obra que necessite de Licenciamento Ambiental deve passar por um levantamento arqueológico prévio para verificar-se a existência ou não de sítios arqueológicos no local, que necessitem pesquisa e resgate. Isto é garantido pela Portaria IPHAN 230/02. 


\section{A IMPORTÂNCIA dOS SítIOS ARQUeOLÓGICOS}

Os sítios arqueológicos são um patrimônio público e testemunhos de nossa história. Os sítios, pesquisados e interpretados, fornecem informações sobre as sociedades do passado, ajudando a compreender nossa História, e trazendo elementos culturais inéditos. Tais informações são aproveitadas para a construção da História Regional, resultando em material didático para as escolas e público em geral, além de possuir grande potencial turístico. As pesquisas em sítios também resgatam grande quantidade de peças, constituindo importantes acervos para o município, que pode utilizá-lo em exposições e na formação de Museus.

\section{AS LEIS QUE PROTEGEM OS SÍTIOS ARQUEOLÓGICOS}

LEI 3924, de 26 de julho de 1961 (Trechos selecionados)

“Dispõe sobre os monumentos arqueológicos e pré-históricos.

O Presidente da República:

Faço saber que o Congresso Nacional decreta e eu sanciono a seguinte lei:

Art. 1ำ - Os monumentos arqueológicos ou pré-históricos de qualquer natureza existentes no território nacional e todos os elementos que neles se encontram ficam sob a guarda e proteção do Poder Público, de acordo com o que estabelece o Art. 180 da Constituição Federal.

Parágrafo único - A propriedade da superfície, regida pelo direito comum, não inclui a das jazidas arqueológicas ou pré-históricas, nem a dos objetos nelas incorporados na forma do Art. 152 (art. 168. CF 1988) da mesma Constituição. (...)

Art. 3o - São proibidos em todo território nacional o aproveitamento econômico, a destruição ou mutilação, para qualquer fim, das jazidas arqueológicas ou pré-históricas conhecidas como sambaquis, casqueiros, concheiros, birbigueiras ou sernambis, e bem assim dos sítios, inscrições e objetos enumerados nas alíneas "b", "c" e "d" do artigo anterior, antes de serem devidamente pesquisados, respeitadas as concessões anteriores e não caducas. (...)

Art. 17, (...) Parágrafo Único - O proprietário ou ocupante do imóvel onde se tiver verificado o achado é responsável pela conservação provisória da coisa descoberta, até pronunciamento e deliberação da Diretoria do Patrimônio Histórico e Artístico Nacional". 


\section{Constituicão Federal de 1988}

“(...) Capítulo II, Da União

Art. 20 - São bens da União:

(...)

X - As cavidades naturais subterrâneas e os sítios arqueológicos e pré-históricos. (...)"

\section{Lei no 9.605/98}

"Dispõe sobre as sanções penais e administrativas derivadas de condutas e atividades lesivas ao meio ambiente e dá outras providências. (...)

\section{DOS CRIMES CONTRA O MEIO AMBIENTE}

\section{SEÇÃo IV}

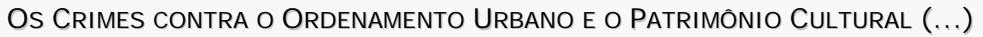

ART. 62 - DESTRUIR, INUTILIZAR OU DETERIORAR:

I - BEM ESPECIALMENTE PROTEGIDO POR LEI, ATO ADMINISTRATIVO OU DECISÃo JUdICIAL; (...)"

\section{DeCReto-Lei № 2.848, de 7 de dezembro de 1940}

\section{"Código Penal (...)}

Título II

Dos crimes contra o patrimônio (...)

Capítulo IV

Do dano (...)

Dano em coisa de valor artístico, arqueológico ou histórico

Art. 163 - Destruir, inutilizar ou deteriorar coisa alheia:

Pena - detenção de 1 (um) a 6 (seis) meses ou multa.

Parágrafo único. Se o crime é cometido:

I - com violência à pessoa ou grave ameaça;

II - com emprego de substância inflamável ou explosiva, se o fato não constitui crime mais grave;

III - contra o patrimônio da União, Estado, Município, empresa concessionária de serviços públicos, ou sociedade de economia mista;

IV - por motivo egoístico ou com prejuízo considerável para a vítima:

Pena - detenção, de 6 (seis) meses a 3 (três) anos, e multa, além da pena correspondente à violência. (...)

Art. 165 - Destruir, inutilizar ou deteriorar coisa tombada pela autoridade competente em virtude de valor artístico, arqueológico ou histórico:

Pena - detenção, de 6 (seis) meses a 2 (dois) anos, e multa". 
Outro problema relevante se refere à elaboração do Plano Diretor de Ilhabela, que não contemplou adequadamente a preservação do patrimônio arqueológico, prevendo um zoneamento para sua preservação que "congela" os sítios em zonas especiais, juntamente com outros tipos de bens culturais e ambientais, ao invés de um zoneamento específico, com uma dinâmica diferenciada. O Plano também não identifica essas áreas.

Por outro lado, além do conhecimento gerado pelas pesquisas arqueológicas alterar o que se conhecia sobre a história local, teceu um novo quadro para o povoamento pré-colonial do litoral sudeste, principalmente pela grande quantidade de sítios Concheiros, abrigos sob rocha e sítios ceramistas, estes últimos provavelmente de tradição Itararé.
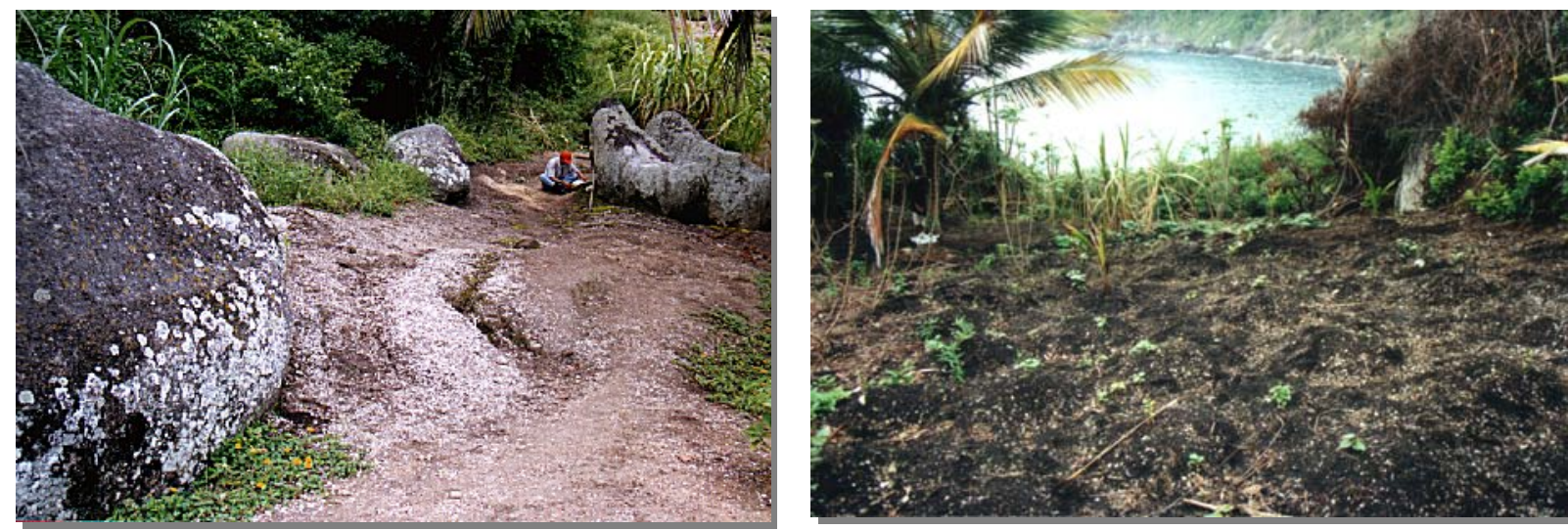

Figs. 14 a 17: Nas fotografias acima, dois sítios Concheiros: Sítio Concheiro Búzios III (esquerda) e Sítio Concheiro Vitória IV (direita). Abaixo, à esquerda, Sítio Aldeia Viana; e à direita Sítio Abrigo Búzios II
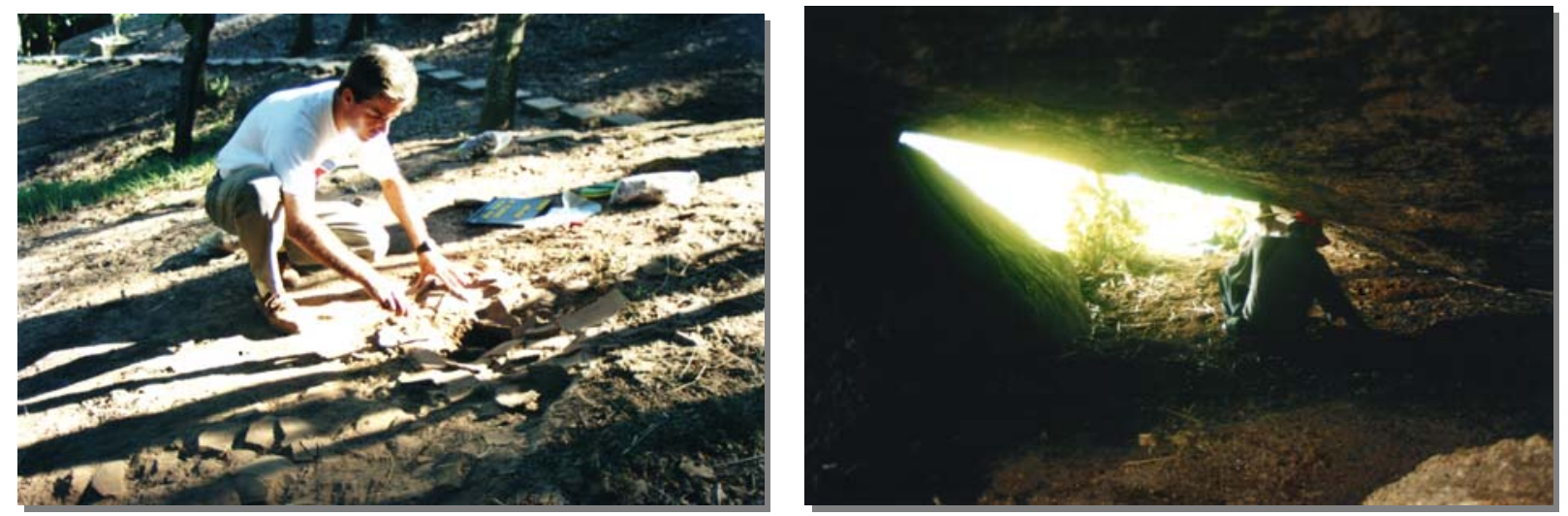
Apesar dos conflitos na área imobiliária, foi possível evitar a destruição de vários sítios, e promover e divulgar os resultados obtidos, através de um significativo número de palestras, cursos, artigos em jornais, revistas e livros $^{60}$, além de matérias televisivas ${ }^{61} \mathrm{e}$ na Internet ${ }^{62}$. Também foram realizadas quatro exposições temporárias.

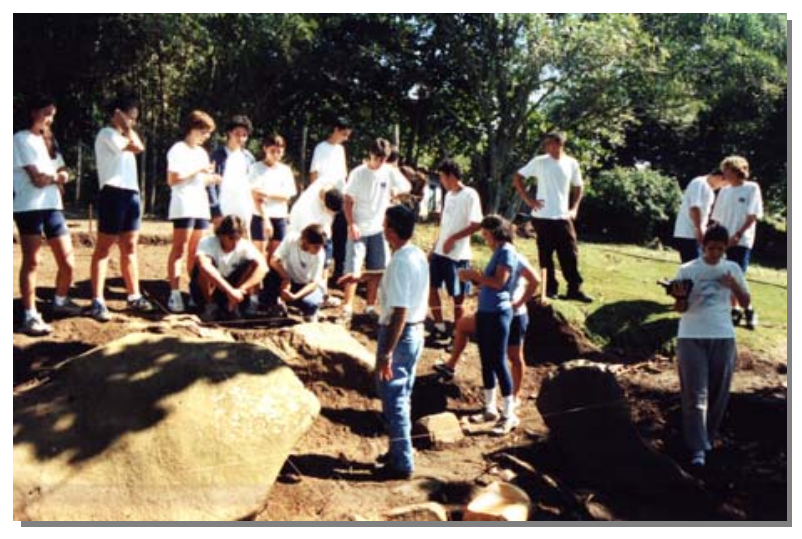

Fig. 18: Visita monitorada no Sítio Engenho Pacuíba com estudantes da cidade

Também foi elaborado um curso de capacitação dos professores sobre a História do município, utilizando e divulgando o conhecimento construído a partir das pesquisas do Projeto Arqueológico. Assim, a história local está sendo incorporada a grade curricular das escolas do município, sendo optativo às escolas estaduais e aos colégios particulares.
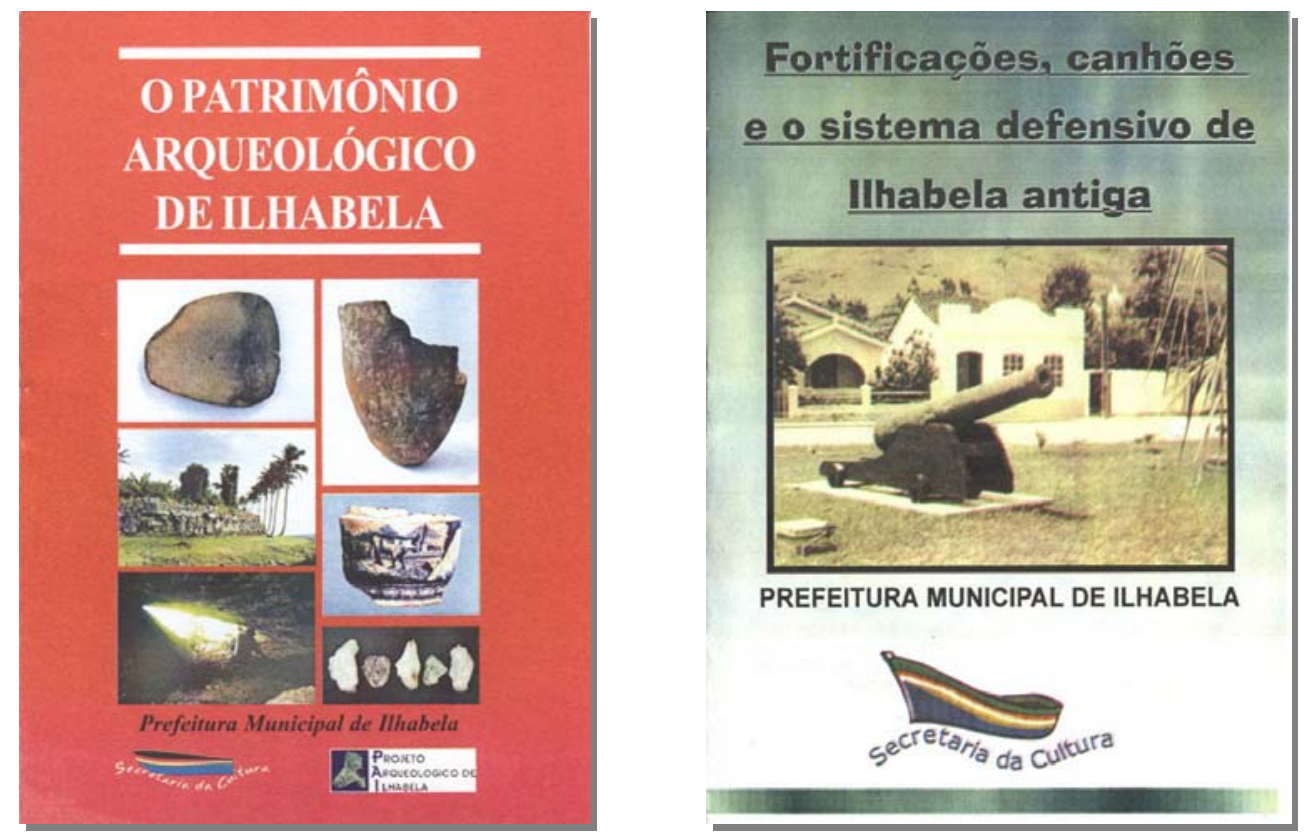

Figs. 19 e 20:

Publicações da Secretaria Municipal da

Cultura sobre 0 Patrimônio

Arqueológico de Ilhabela.

Cartilhas da

Cultura n오 05 e $07 / 2004$

60 Desde 2000, o Projeto publicou 33 trabalhos impressos, sendo 01 livro, 03 Cartilhas, 03 publicações de Congressos e 26 artigos em jornais. Também produziu 01 vídeo documentário. Já a imprensa escrita realizou 39 matérias sobre o Projeto e o Patrimônio Arqueológico de llhabela em diferentes jornais e revistas.

${ }^{61}$ Na mídia televisiva o Projeto foi destaque em 04 ocasiões na TV Vanguarda, Regional da Rede Globo e 02 na TV Band Vale (Regional da TV Bandeirantes).

${ }^{62}$ Há dezenas de referências sobre o Projeto e os trabalhos arqueológicos na Rede Mundial de Computadores (Internet). Em 2003 foi criado o Site do Projeto Arqueológico de Ilhabela (http://arqueologia.ilha.sites.uol.com.br). Em maio de 2005 o Site foi escolhido pelo Provedor UOL entre os melhores mantidos sob seu domínio. 
Em 2005 foi disponibilizado novo espaço ao Instituto Histórico, com novo Laboratório Arqueológico, Reserva Técnica e Exposição Permanente, além de ser montada uma equipe técnica que está atuando em pesquisa e resgate de documentação textual e iconográfica, trabalho com o acervo de 18.000 peças arqueológicas existentes, além de ampliar as pesquisas arqueológicas.

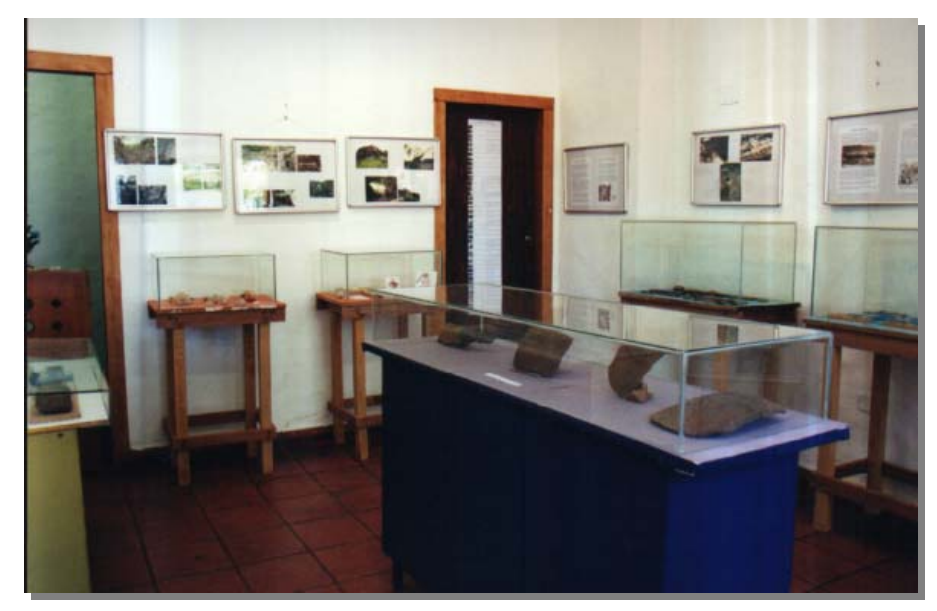

Fig. 21: Exposição "Os Primeiros Habitantes de Ilhabela", Secretaria Municipal da Cultura, 2000

Também estão em elaboração projetos para criação de um Conselho Municipal de Patrimônio Cultural, Lei de Tombamento, Definição de um Zoneamento Arqueológico e uma Lei Municipal de Arqueologia de caráter suplementar.

Outro destaque é o projeto para aproveitamento turístico de alguns sítios arqueológicos. Tal projeto surgiu considerando o potencial turístico dos sítios, a vocação turística do município e a necessidade de se oferecer atrativos diferenciados e como opção a sazonalidade. Isto, conciliado a necessidade de divulgar o patrimônio com vistas à educação e conscientização da comunidade, levou à seleção de alguns sítios para esse fim. Os critérios de seleção consideraram a importância de cada sítio, localização e acessibilidade e levaram ao estabelecimento de roteiros de visitação, conciliando os sítios com outros bens culturais e ambientais. O projeto contempla uma estrutura mínima para garantir a proteção dos sítios e diversas formas de comunicação visual contendo informações e imagens sobre o local, de forma a dar sentido, visibilidade e compreensão sobre o que era cada um daqueles locais e sua história. ${ }^{63}$ Entretanto, tal projeto ainda não foi implantado.

${ }^{63}$ CALI, Plácido; COSTA, Rafaela de Sá Lopes da. Projeto para aproveitamento turístico de quatro sítios arqueológicos em Ilhabela. Ilhabela: Projeto Arqueológico de Ilhabela, 2003. 


\section{8 - INDAIATUBA - SP}

A cidade de Indaiatuba (SP) possui um Conselho Municipal de Preservação, criado pela Lei Municipal 3328 de 11 de junho de 1996. Este Conselho é um órgão deliberativo vinculado à Fundação Pró-Memória de Indaiatuba, ao qual compete formular as diretrizes e estratégias necessárias para garantir a preservação de bens culturais do município de Indaiatuba.

Cabe ao Conselho propor ou analisar os pedidos de tombamento de bens móveis ou imóveis. Cada tombamento deve ser inscrito no respectivo livro de tombo:

I - Livro de Registro dos Bens Naturais, incluindo-se paisagens excepcionais, espaços ecológicos relevantes e recursos hídricos; II - Livro de Registro dos Bens Imóveis de valor histórico, artístico, folclórico, arqueológico, e etnográfico, inclusive sistema viário, conjunto arquitetônico, parque, logradouros públicos e espaços de lazer urbanos, edificados ou não;

III - Livro de Registro de Bens Móveis, incluindo-se acervos de museus, coleções particulares, públicas, peças isoladas de propriedades identificadas, documentos raros de arquivos, mapas, cartas, plantas, fotografias e documentos.

A Prefeitura Municipal de Indaiatuba concede aos proprietários de bens imóveis tombados os seguintes incentivos fiscais na forma de isenção:

I - do pagamento de Imposto Predial e Territorial Urbano, de contribuição de melhoria e de taxas de serviços públicos sobre eles incidentes;

II - do pagamento do ISSQN (Imposto Sobre Serviços de Qualquer Natureza) e taxas que incidirem sobre qualquer forma do imóvel tombado ou sobre qualquer prestação de serviço desenvolvida no mesmo. 
Embora o município efetue o tombamento de bens móveis e imóveis, não possui lei municipal específica de tombamento. O tombamento ocorre por Resolução do Conselho Municipal de Patrimônio, homologado pelo Prefeito Municipal. O município possui 17 bens imóveis tombados.

Embora a Lei de criação do Conselho Municipal de Patrimônio (CMP) tenha considerado os bens arqueológicos dentre os vários a serem protegidos pela municipalidade, até o momento não ocorreu nenhum caso desta natureza. Entretanto, a Resolução CMP n 02/97 que tratou da abertura do processo de tombamento da Fazenda Engenho d'Água, considerou como área de proteção o entorno da edificação - sede da fazenda, abrangendo toda a quadra em que se encontra, "e que apresenta grande potencial arqueológico".

\section{9 - JOINVILLE - SC}

A cidade de Joinville/SC destaca-se pela atuação do Museu Arqueológico de Sambaqui. Seu acervo constituiu-se, inicialmente, de 12.000 peças, originadas, principalmente, de sambaquis, graças à aquisição pela Prefeitura Municipal, em 1963. Essa coleção foi formada por Guilherme Tiburtius, nascido em Berlim em 1892, e radicado no Brasil desde 1910.

O Museu Arqueológico de Sambaqui de Joinville foi fundado em 1969 e inaugurado em 1972. Sua trajetória esteve ligada fortemente à preservação dos sítios, servindo de intermediário nas ações da então SPHAN-PróMemória (BRUNO et al., 1991). As causas de destruição dos sítios do município são as mesmas já apontadas para todo o Estado de Santa Catarina por Edna J. Morley (1999: 372 - 373): obras de grande porte, aproveitamento econômico das áreas arqueológicas e vandalismo.

Em 1989, o Museu passou por uma reestruturação de suas atividades, sendo a questão da preservação uma das prioridades. Mas “(...) o processo educativo com escolares demandava muito tempo para apresentar resultados práticos, enquanto sítios continuavam a ser agredidos" (AFONSO et al., 1991: 114). Adotaram-se duas estratégias para curto e médio prazo. O projeto "Adote um Sambaqui" visava 
resultados imediatos na preservação, no qual empresas e pessoas físicas participavam da proteção, sendo os sambaquis cercados e vigiados.

A médio prazo foram elaboradas exposições direcionadas para temas ligados à preservação dos sítios, tais como a exposição itinerante "SOS SAMBAQUIS" e o projeto educativo no Sambaqui Espinheiros II, visando minimizar os impactos de trinta famílias que habitavam sobre o sítio. Já a exposição permanente "Pré-História Regional" (1991), foi reformulada com a assessoria da equipe do Museu de Arqueologia (MAE)/USP e do Museu Paraense Emílio Goeldi/CNPq (Belém/PA).

Apesar das ações do MASJ, a situação dos sambaquis do município é preocupante. Joinville possui 42 sambaquis inventariados e, segundo Oliveira (2000: 162 e 163), 69\% deles são de propriedade desconhecida, 19\% estão em terrenos particulares e 12\% estão em área da Prefeitura Municipal. O autor também constatou que $70 \%$ dos sambaquis não possuem qualquer tipo de infra-estrutura.

Em 1994, o MASJ e a Fundação Instituto de Pesquisa e Planejamento Urbano de Joinville, atual IPPUJ, produziu o documento Sítios Arqueológicos em Joinville/SC: inventário descritivo básico. Esse inventário trouxe informações precisas quanto a sua localização e estado de conservação (BANDEIRA, 2001: 05). Já em 1997, foi realizado com o apoio financeiro do IPHAN, o projeto Atualização Cadastral e Reconhecimento de Sítios Arqueológicos no município de Joinville - SC. Somente a primeira etapa do projeto, referente ao recadastramento dos sítios foi realizada.

O MASJ também tem realizado um papel fiscalizador importante nos sambaquis da cidade, bem como vem fazendo o acompanhamento das audiências públicas de licenciamentos ambientais. O MASJ não desenvolve trabalhos arqueológicos em empreendimentos que exigem estudo de impacto ambiental. Entretanto, o Museu realiza trabalhos de Arqueologia por Contrato em obras da cidade (BANDEIRA, 2001: 06).

Recentemente o MASJ tem empreendido esforços no sentido da criação de um zoneamento para o Complexo Arqueológico Caieira. Trata-se de uma área associada ao Sambaqui Lagoa do Saguaçu, e que contém duas Oficinas Líticas 
(Lagoa do Saguaçu e Caieira), fornos e casas. A proposta é criar uma Zona Histórico-Cultural - ZHC, dividida em três categorias ${ }^{64}$.

a) Zona Arqueológica Primitiva - ZAP

Objetiva preservar estruturas arqueológicas para facilitar pesquisas e 0 acesso público sob restrições. Apresenta estruturas arqueológicas. Qualquer tipo de interferência na área somente será aceita visando à proteção dos sítios.

b) Zona Arqueológica de Uso Extensivo - ZAE

Visa manter uma área de proteção de entorno mínima, com estruturas para a promoção da área. Possui aterros com conchas, da época de funcionamento da Caieira. Determina estudo arqueológico prévio no caso de novas edificações.

c) Zona Arqueológica de Uso Intensivo - ZAI

Voltada para atividades de educação ambiental. Esta área não apresenta cultura material associada aos sítios arqueológicos. Sujeita novas edificações apenas ao monitoramento arqueológico.

As preocupações da equipe do MASJ com relação à área do Complexo Arqueológico Caieira aumentaram em função do projeto de criação do Parque Ambiental Caieiras. Tal projeto foi elaborado sem contemplar a preservação do patrimônio arqueológico, pretendendo-se ocupar as zonas arqueológicas de uso restrito, com a seguinte infraestrutura: churrasqueiras, sanitários, vestiários, campo de futebol, quadra poliesportiva, restaurante, lojas, mirante playground, ciclovia, estacionamento, acesso para veículos, bancos e um laboratório de Arqueologia. Ao todo, está prevista uma área para edificações de 15.708,66 m².

Caso esse Parque venha a ser implantado, o MASJ sugere o remanejamento de diversas edificações e atividades para zonas de menor restrição. Entretanto, o

\footnotetext{
${ }^{64}$ Diagnóstico Arqueológico e Paleoambiental como subsídio ao Zoneamento e Conservação do Complexo Arqueológico de Caieira: Lagoa do Saguaçu, Joinville/SC. Relatório Final. Joinville: MASJ, outubro de 2001.
} 
impacto do Parque na área seria enorme. Mesmo com alterações no projeto e salvamento arqueológico a perda desse patrimônio seria irreparável.

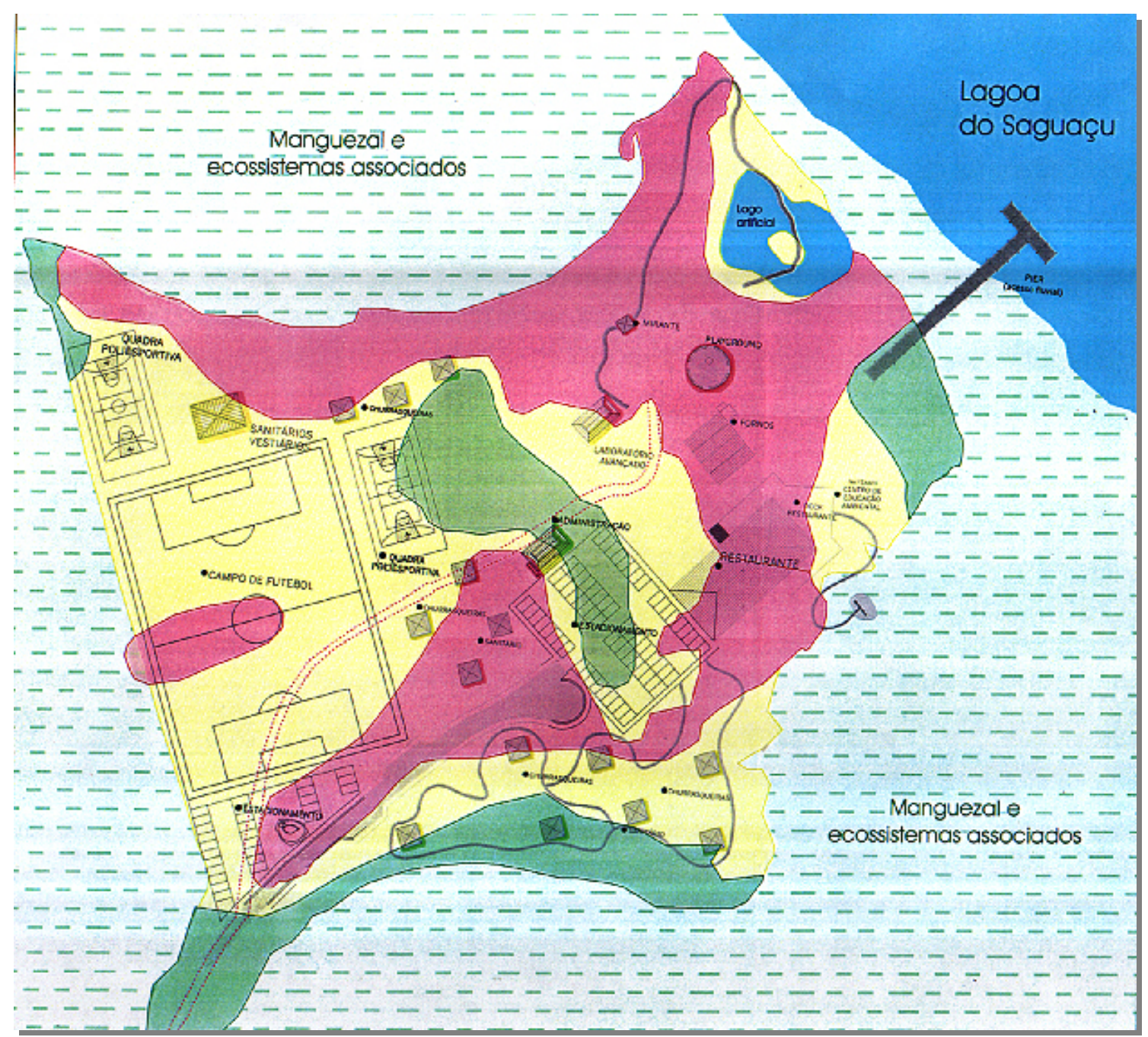

Zona Arqueológica Primitiva - ZAP

Zona Arqueolóqica de Uso Extensivo - ZAE

Zona Arqueológica de Uso Intensivo - ZAI
Fig. 22: Área do Complexo Arqueológico Caieira, com as zonas de proteção e assinalando, também, os equipamentos do Parque e mostrando sua incompatibilidade com 0 zoneamento arqueológico. Fonte: Museu Arqueológico do Sambaqui de Joinville ${ }^{65}$

O município de Joinville possui o Núcleo do Patrimônio Histórico, ligado a Coordenadoria do Patrimônio Histórico da Fundação Cultural de Joinville. Também possui a Lei $\mathrm{n}^{\circ} 1773 / 80$, que dispõe sobre a proteção do Patrimônio Cultural do município. Entretanto, a atuação deste Núcleo e da Coordenadoria tem sido

\footnotetext{
${ }^{65}$ Diagnóstico Arqueológico e Paleoambiental como Subsídio ao Zoneamento e Conservação do Complexo Arqueológico Caieira: Lagoa do Saguaçu, Joinville/SC. Joinville: MASJ,
} 2001 
bastante limitada, com ações no patrimônio edificado. Ainda assim, Joinville possui apenas cinco edificações tombadas, sendo três pelo Estado e duas pela União.

Joinville, através do MASJ, vem atuando na preservação, resgate e promoção dos sambaquis. Tal atuação, entretanto, não abrange o universo do patrimônio arqueológico da cidade. Nesse sentido, técnicos do Museu têm tentado inserir a Arqueologia nos trabalhos com o patrimônio edificado e com outros tipos de sítios pré-coloniais, principalmente os ceramistas. O projeto Atualização Cadastral e Reconhecimento de Sítios Arqueológicos no município de Joinville - SC, já buscou contemplar esse tipo de sítio. A pesquisa arqueológica em sítios mais recentes irá permitir repensar o papel da colonização do município e a sua história. Todos os livros didáticos que analisamos apresentam a história a partir da colonização européia. Alguns poucos fazem referências aos sambaquis, mas há um intervalo de milhares de anos entre os homens dos sambaquis e a chegada dos colonizadores em que nada é mencionado.

\subsection{0 - LAGUNA - SC}

O centro histórico de Laguna foi tombado em nível nacional em 1985. Também se destaca pela presença de vários sambaquis. O IPHAN possui, em Laguna, um escritório técnico, depois transformado no Laboratório de Estudos e Pesquisas LEP-Laguna.

O município de Laguna, Santa Catarina, possui um centro histórico tombado pelo patrimônio nacional. Localizada às margens da Lagoa de Santo Antônio, parte do maior complexo lagunar do estado, abriga também vários sambaquis.

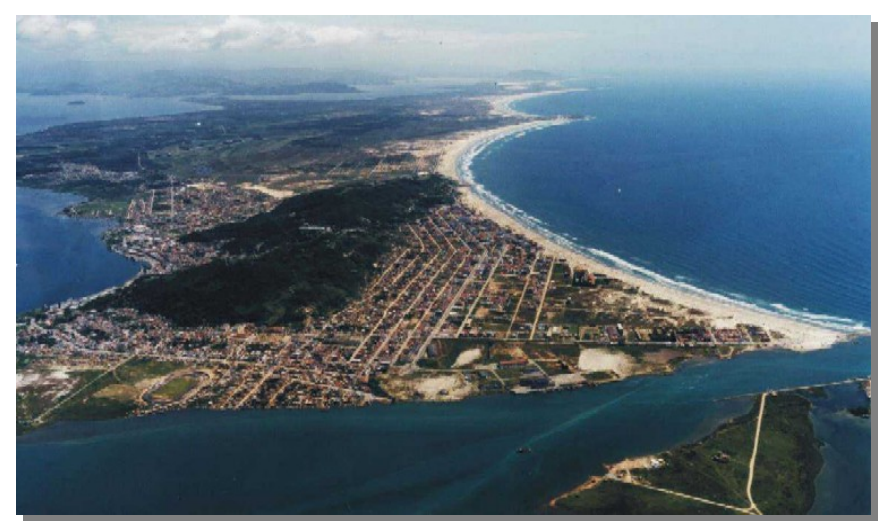

Fig. 23: Vista aérea de Laguna. Projeto URBIS, 2001 
A preocupação do município com seu patrimônio remonta a setembro de 1974, com a criação do Conselho Municipal de Cultura, através da Lei 28/74. Em seu artigo 12, itens "d" e "l", a lei atribuiu ao Conselho competência para "articular medidas visando à valorização da paisagem cultural e da paisagem natural do município, representadas em suas múltiplas formas", bem como "incentivar estudos e medidas destinadas à defesa e ao tombamento de documentação existente nos velhos cartórios e igrejas".

Essa preocupação permitiu a criação da Lei $n^{\circ}$ 34, de 03 de novembro de 1977, que dispõe sobre a proteção do patrimônio histórico. É a lei municipal mais antiga que conhecemos. Ela permite o tombamento municipal de bens móveis ou imóveis, a critério da Comissão Municipal de Cultura, órgão subordinado ao Gabinete do Prefeito. O bem tombado fica isento de IPTU.

Área Tombada em nível Federal. Centro Histórico de Laguna

Área complementar do Projeto URBIS. Ponta das Pedras

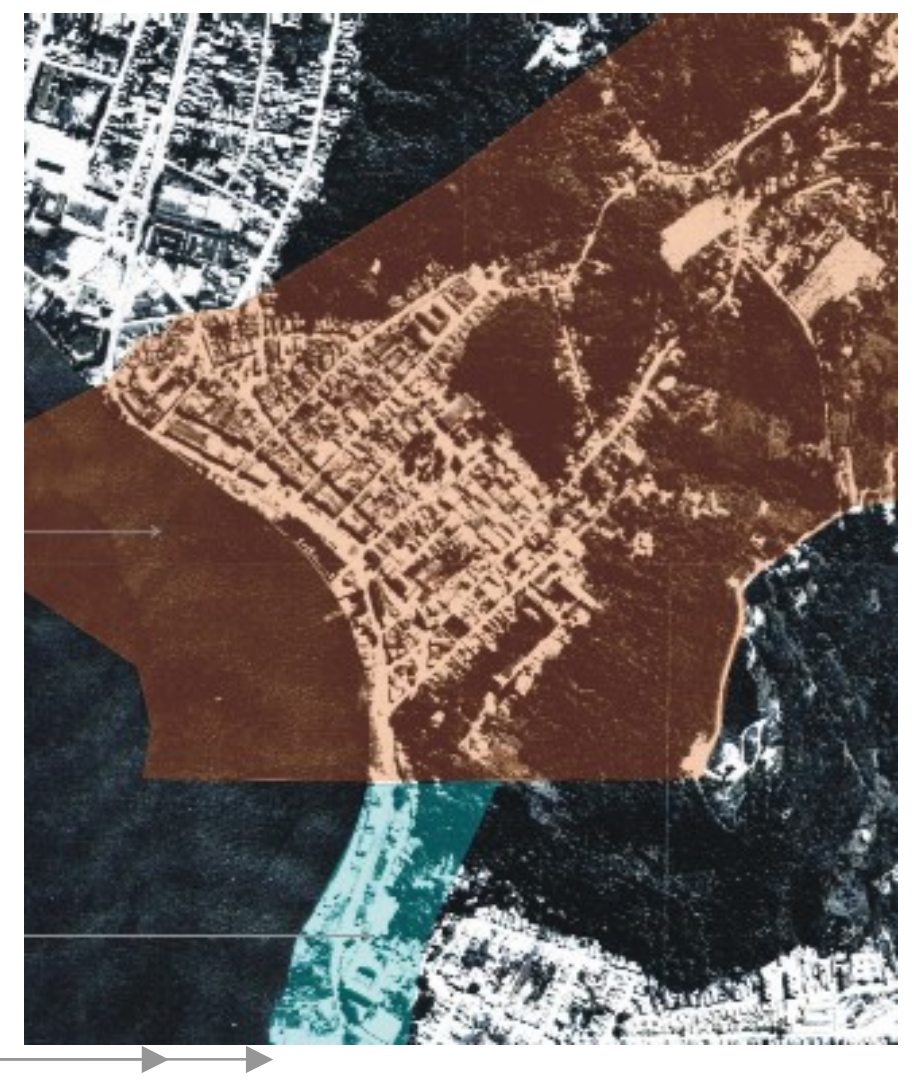

Fig. 24: Foto aérea do Centro Histórico de Laguna. 1995. Projeto URBIS

Um dos objetivos era a criação de um escritório regional do IPHAN em Laguna, o que de fato veio a acontecer. 
Em 1989, a Prefeitura Municipal de Laguna e a Fundação Catarinense de Cultura, com o apoio de vários órgãos (entre eles o antigo SPHAN), elaboraram e publicaram o $1^{\circ}$ volume do Cadernos da Laguna. Esta publicação foi produzida para ser utilizada na rede escolar de Laguna, visando suprir à falta de bibliografia sobre a cidade. Propunha-se, ainda, a servir para divulgação junto à comunidade, turistas e visitantes de museus de Laguna.

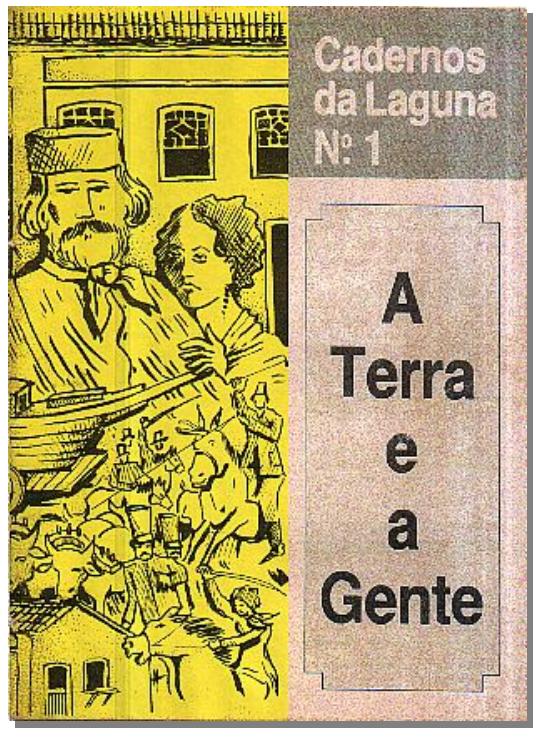

Esse Caderno, entretanto, apresenta uma série de problemas e equívocos, principalmente por sua visão linear e positivista da história lagunense. Destacamos a parte que trata dos sambaquis. O título é "Sambaquis - Diário dos Carijós" ${ }^{66}$. Pelo título já se percebe a confusão.
"Aí apareceram pontas de flechas, machadinhas, colares de conchas e... uma grande urna funerária, vaso de barro cozido, e dentro o morto (...). Os sambaquis atestam que os Carijós eram sedentários e que usavam instrumentos feitos de pedra para cortar, triturar, moer e perfurar; vasilhames de cerâmica cozida para carregar, cozinhar e armazenar alimentos, objetos e adornos artísticos de conchas, fibras e penas. As peças cerâmicas mostram um refinado senso estético, prova de que nossos antepassados depararam com uma invulgar civilização da qual os sambaquis são os últimos arquivos".

Vê-se pelo texto do Caderno, a confusão entre grupos de pescadores-coletores dos sambaquis, com milhares de anos, com grupos agricultores/ceramistas, conhecidos como Carijós, cuja presença na região é bem mais recente.

\footnotetext{
${ }^{66}$ GOVERNO DO ESTADO DE SANTA CATARINA. A Terra e a Gente. Cadernos da Laguna $\mathrm{n}^{\circ} 01$. Santa Catarina: Fundação Catarinense de Cultura. 1989.
} 
Outra publicação da Prefeitura Municipal de Laguna também merece destaque. Intitula-se "Vultos Lagunenses". A obra apresenta os principais expoentes de Laguna, enaltecendo-os e incentivando a construção histórica do município em torno dessas personagens ${ }^{67}$.

Em julho de 2000, a Lei Orgânica do Município definiu, em seu artigo 129 - parágrafo $2^{\circ}$, as áreas de preservação permanente de Laguna. E fazem parte dessas áreas os sítios arqueológicos. O artigo 139, em seu Parágrafo único, também considera os sítios arqueológicos, entre os bens a serem protegidos pelo

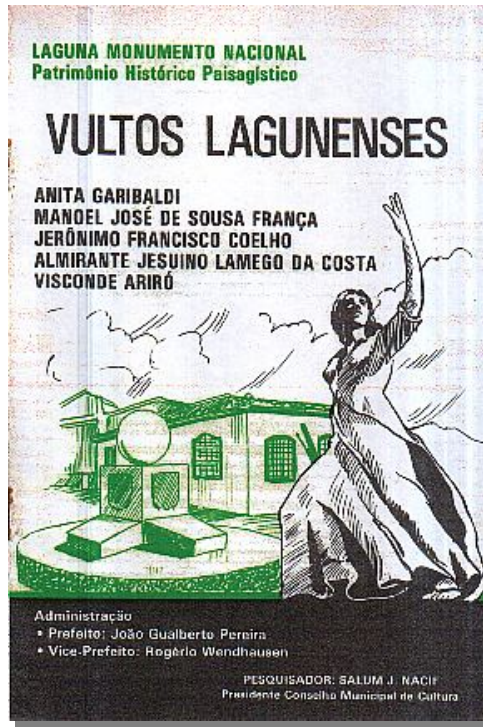

Fig. 26 município.

Recentemente, parcerias estabelecidas entre o IPHAN e a Prefeitura Municipal de Laguna têm resultado em interessantes projetos visando à revitalização e promoção do patrimônio. Acredita-se que essas ações sejam responsáveis pelo aumento dos índices de motivação para viagens à Laguna. Dados de 2001 já indicavam que $19,61 \%$ dos turistas procuram Laguna pelos atrativos histórico-culturais, contra $54,19 \%$ em função dos atrativos naturais. Em 1998, o primeiro item era responsável apenas por $5,78 \%$.

Dentre os principais projetos na área, atualmente em elaboração, está o plano de revitalização, chamado de Urbis, e o Sistema Integrado de Museus de Laguna. O primeiro está inserido num projeto mais amplo do governo federal, com financiamento da Caixa Econômica Federal, para a revitalização de cidades tombadas pelo patrimônio nacional. Sete cidades em todo o país foram contempladas nesse projeto, sendo Laguna a única cidade contemplada do estado de Santa Catarina. Apesar do caráter amplo desse projeto, não constatamos a inserção do patrimônio arqueológico, dentre os objetos contemplados no Projeto Urbis. Alega-se seu caráter vinculado ao patrimônio edificado, considerado prioritário na revitalização da cidade.

\footnotetext{
${ }^{67}$ PREFEITURA MUNICIPAL DE LAGUNA. Vultos Lagunenses. Laguna, 1987.
} 
Já o Sistema Integrado de Museus de Laguna visa qualificar os museus locais existentes e implantar novos museus, adquirindo-se novos acervos e gerando pontos atrativos na cidade, consolidando a vocação da cidade de "pólo cultural regional".

\subsection{1 - MAUÁ - SP}

A cidade de Mauá possui o Conselho de Defesa do Patrimônio Histórico, Artístico, Arqueológico e Turístico. Criado pela Lei Orgânica e regulamentado pelo Decreto 5.824/98, o Conselho é subordinado à Secretaria Municipal de Cultura e Esportes. Este Conselho é composto por 06 membros designados pelo Prefeito Municipal, sendo metade da Prefeitura Municipal e metade de "pessoas ligadas ao estudo da preservação da memória do Município".

Diferentemente dos demais Conselhos Municipais de Patrimônio, o Conselho de Mauá somente se manifesta sobre bens de propriedade do município, tornando sua ação bastante restrita.

\subsection{2 - PERUÍBE / SP}

O município de Peruíbe possui um Conselho de Patrimônio criado pela lei 2517/04, lei que também estabeleceu as normas para tombamento de Bens Culturais. Apesar do Conselho possuir uma composição majoritária de representantes da sociedade civil (2/3), faltam critérios para a escolha de alguns membros, bem como contempla a participação de representante da Câmara Municipal, o que é problemático, já que o Conselho é um órgão do Poder Executivo.

A lei 2517 é uma das únicas que não protegem o bem objeto de um pedido de tombamento enquanto o processo é julgado. A exemplo do Condephaat, essa lei estabelece um raio de 300 metros de proteção ao imóvel tombado, com critérios similares ao do órgão estadual, o que é incomum para leis municipais na área. 
A partir de 1991 a Prefeitura Municipal incentivou e investiu no resgate de um sítio arqueológico histórico, Ruínas do Abarebebê, que envolveu e sensibilizou a comunidade. Entretanto, o projeto não contemplou divulgação da pesquisa e resultou no fechamento das ruínas ao público por dez anos. Tal fato causou revolta entre os munícipes e frustração nas Administrações Municipais que, por muito tempo recusaram qualquer discussão sobre resgate do patrimônio arqueológico.

Com a determinação da abertura do sítio à visitação pública, pelo IPHAN, o cenário começou a mudar.

Em fevereiro de 2002, conseguimos criar o Museu Histórico e Arqueológico de Peruíbe, recebendo o acervo proveniente de sítios arqueológicos pesquisados pelo Projeto Arqueológico Juréia-Itatins, que coordenamos durante o Mestrado no MAE/USP, com o financiamento da FAPESP. Buscamos, com o Museu, criar uma instituição responsável pela promoção e preservação do patrimônio histórico e arqueológico local.

Apesar do pequeno acervo, o Museu tem sido amplamente visitado e já recebeu algumas denúncias de destruição de sítios arqueológicos, que foram encaminhadas ao IPHAN. 


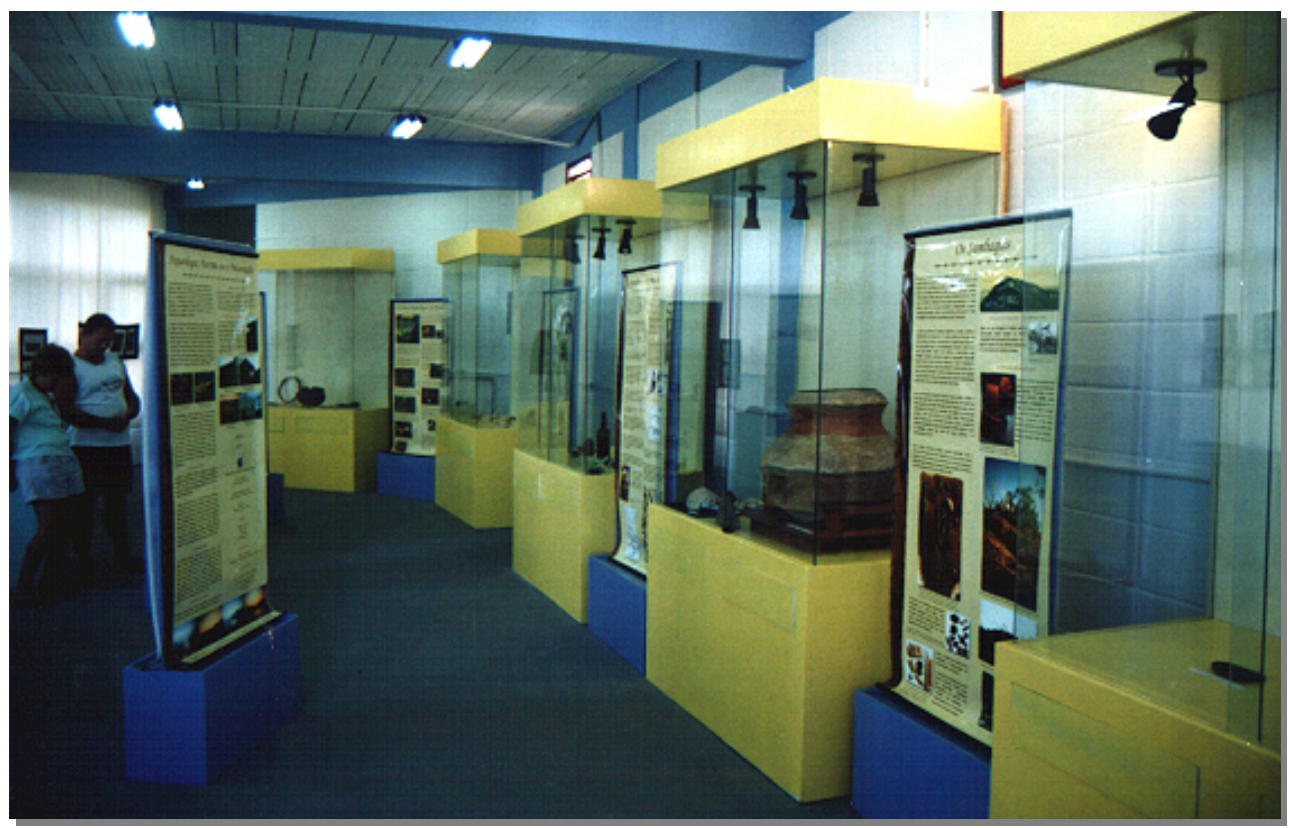

Fig. 27: Vista do interior do Museu Histórico e Arqueológico de Peruíbe, 2002

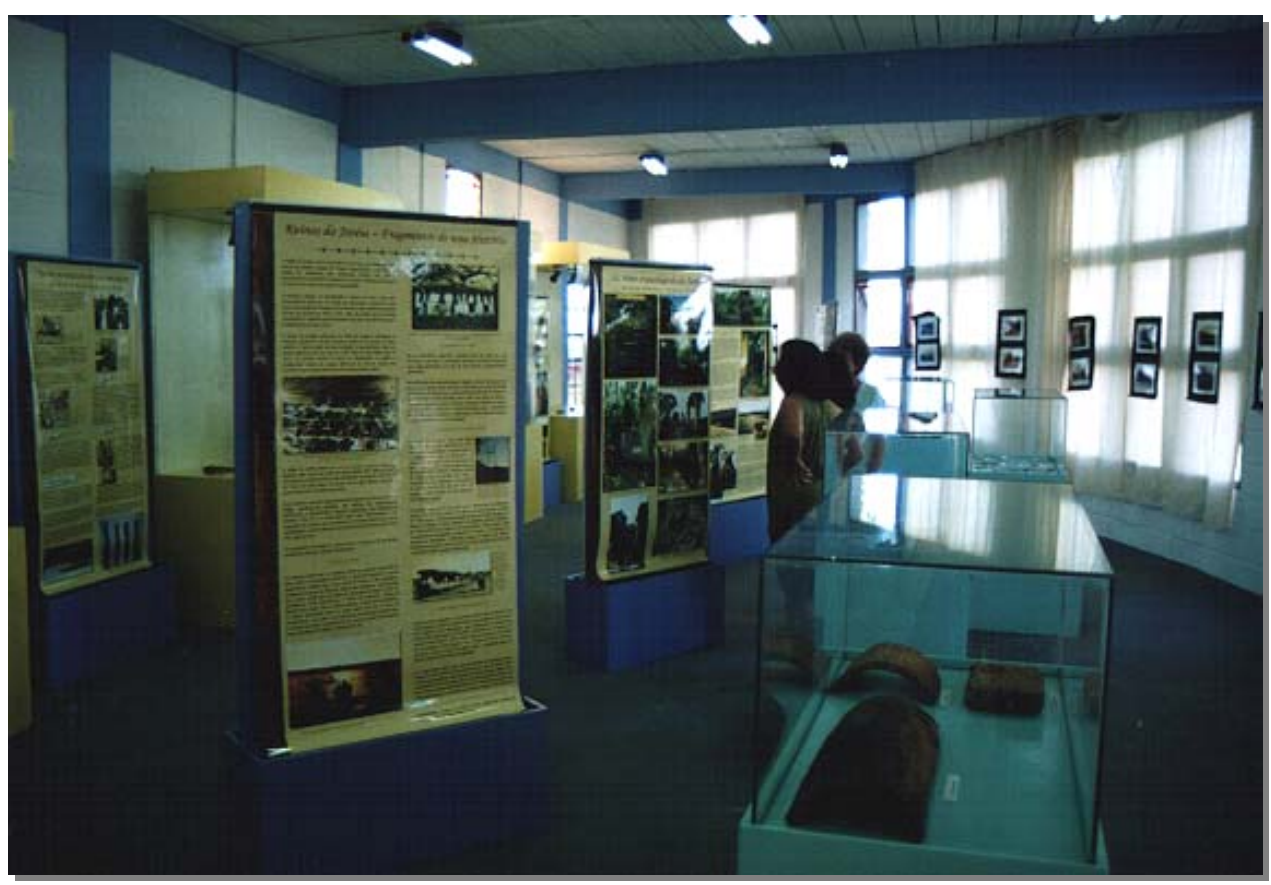

Fig. 28: Vista do interior do Museu Histórico e Arqueológico de Peruíbe, 2002 
O município de Peruíbe possui dezesseis sítios já identificados. Devido à sua vocação turística, o município se interessou em equipamentos que tivessem um aproveitamento turístico, como foi o caso do Museu Histórico e Arqueológico de Peruíbe. Em 2004, houve a implantação do Projeto de Musealização das Ruínas do Abarebebê. Este último projeto, por nós idealizado, seguiu as diretrizes do Guia Brasileiro de Sinalização Turística, transformando um sítio arqueológico em um Museu de Sítio, ou seja, um Bem disposto de diversas formas de comunicação visual contendo informações e imagens sobre o local, de forma a dar sentido, visibilidade e compreensão sobre o que era o antigo aldeamento de São João Batista, a igreja e sua história.

Foram utilizados onze expositores com banners, trabalhando-se com textos e imagens, distribuídos ao longo do sítio arqueológico. A área do sítio está totalmente cercada e com guarita. Próximo da entrada também há uma sala de exposição.

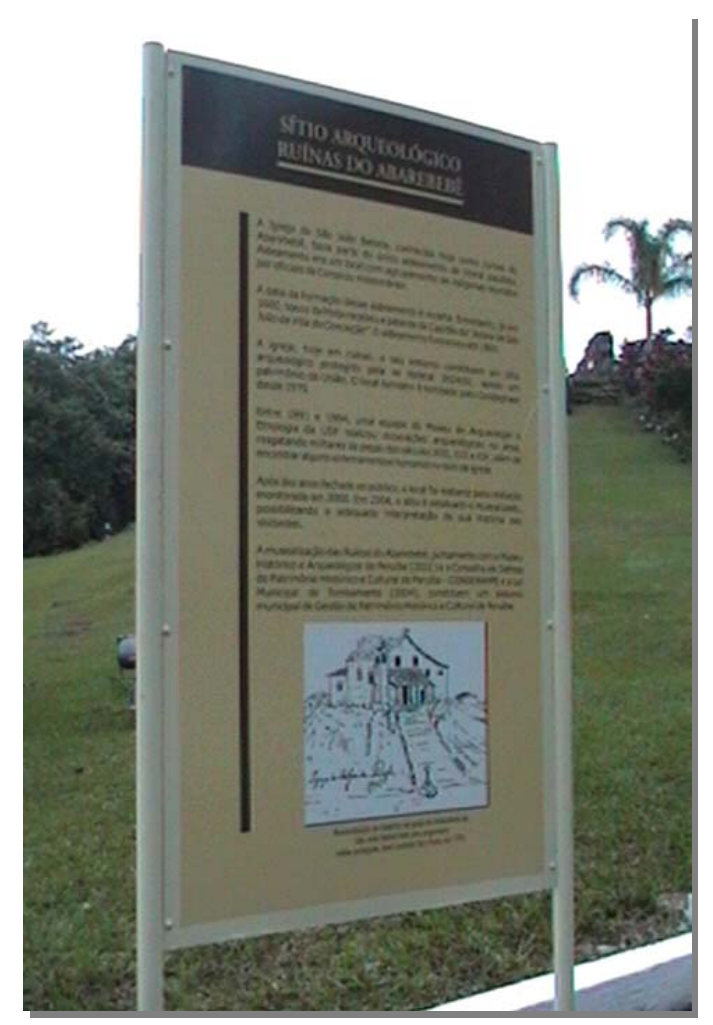

Fig. 29: Expositor situado na entrada do sítio arqueológico 


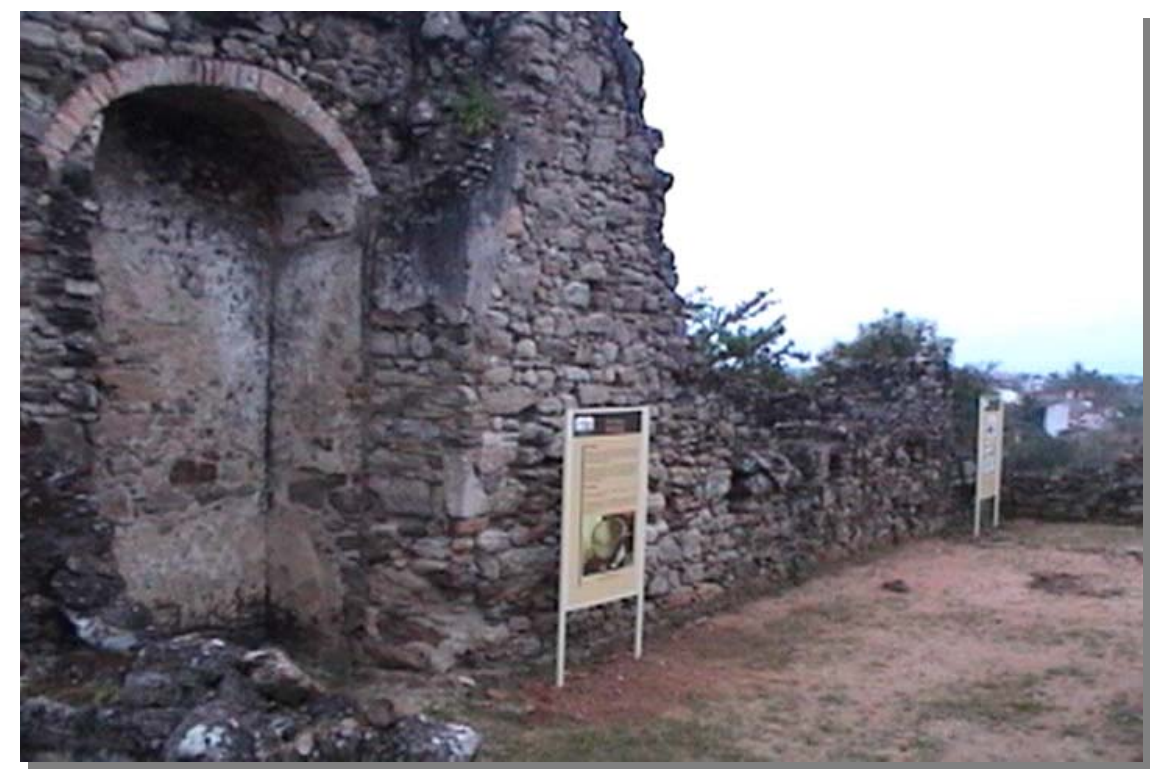

Fig. 30: Interior da ruína da igreja, nave central, tendo o batistério à esquerda

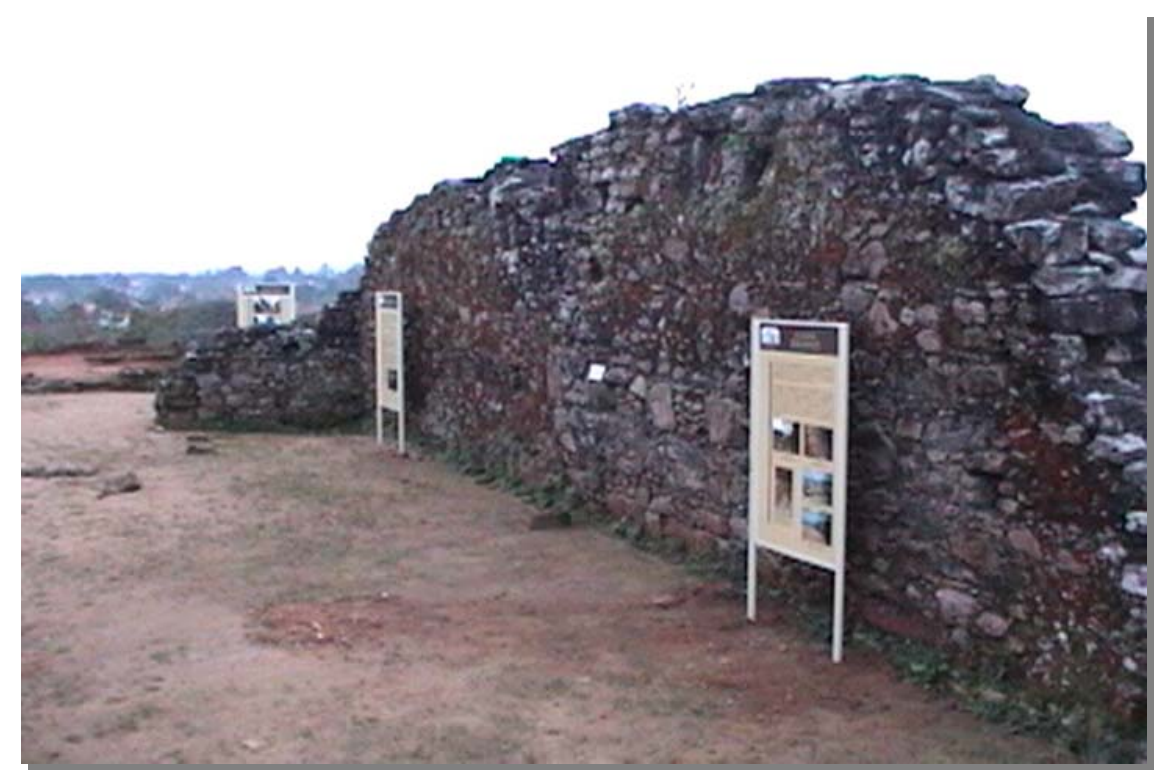

Fig. 31: Interior da ruína da igreja, nave central, com alguns expositores

Com o Conselho de Patrimônio, Lei de Tombamento, Museu e a musealização das ruínas do Abarebebê, o município está formando um sistema de proteção do patrimônio histórico local. 


\subsection{3 - PIRAJU / SP}

O município de Piraju possui uma legislação de patrimônio cultural bastante interessante, pela sua abrangência e por possibilitar maior participação e transparência em suas ações de preservação.

A Lei 1752/92 criou o Conselho Municipal do Meio Ambiente e do Patrimônio Cultural do Município de Piraju. A Lei $n^{\circ}$ 1855/93 tratava do processo de tombamento de bens culturais, ambientais e Paisagísticos do Município de Piraju.

Estas leis foram substituídas por outra, que instituiu o Sistema Municipal de Meio Ambiente e Patrimônio Cultural de Piraju - SISMMAP. Essa lei define os conceitos de Meio Ambiente e Patrimônio Cultural e já estabelece alguns itens patrimoniais como relevantes, como o rio Paranapanema, a antiga Estação Ferroviária, as construções ecléticas do início do século $X X$, os sítios pré-coloniais e a manifestação popular do Moçambique.

Constituem o SISMMAP:

I. Órgão Deliberativo e Recursal: Conselho de Meio Ambiente e Patrimônio Cultural do Município de Piraju

II. Órgão Técnico de Assessoria: Câmara Técnica de Meio Ambiente e Patrimônio Cultural

III. Órgãos Técnicos Executivos: órgãos setoriais de meio ambiente e de cultura existentes no organograma da Prefeitura Municipal

IV. Órgãos Associados: organizações não governamentais associadas ao sistema, em programas, projetos ou ações em parceria.

Dentre as várias atribuições do Conselho de Meio Ambiente e Patrimônio Cultural, que é Deliberativo, cabe destacar a proposta de participar, "mediante a solicitação dos órgãos licenciadores ambientais supra-locais, em caráter supletivo, das ações ligadas ao licenciamento e à fiscalização de atividades, processos e obras que estejam causando ou que possam causar impactos ambientais no Município de Piraju". 
Outro destaque da Lei foi a criação de uma Câmara Técnica de Meio Ambiente e Patrimônio Cultural, órgão técnico de assessoria do Conselho. Obriga-se, assim, o encaminhamento para análise, de qualquer expediente a ser apreciado pelo Conselho. Outras cidades que possuem órgãos de assessoria aos Conselhos são quase sempre órgãos da Prefeitura Municipal. Esta Câmara Técnica de Piraju é formada por três membros escolhidos pelo Prefeito Municipal, mas com "diploma de curso superior em áreas correlacionadas com o meio ambiente e/ou patrimônio cultural e com currículo que destaque estudos e projetos" nessas áreas. Também é vedada a participação de agentes do serviço público municipal na Câmara Técnica. A escolha desses membros é feita pelo candidato ao posto (não remunerado), atendendo a um edital da Prefeitura na imprensa local.

O Conselho é composto por 12 membros, sendo 03 membros da Prefeitura Municipal, 03 de associações civis, 01 do Centro Regional de Arqueologia da USP, 01 representante da Ordem dos Advogados do Brasil, 01 da Polícia Florestal e os 03 membros da Câmara Técnica. O Conselho está estruturado em: Plenário, Presidente e Secretário-Executivo.

\subsection{4 - PORTO ALEGRE / RS}

Porto Alegre possui o Conselho do Patrimônio Histórico Cultural, criado pela Lei $\mathrm{n}^{\circ}$ 4139 de 09 de julho de 1976. O Conselho é composto por quinze membros designados pelo Prefeito, dos quais oito da Prefeitura Municipal e sete vinculados a entidades relacionadas à questão do patrimônio. As entidades que participam do Conselho são: Instituto Histórico e Geográfico do Rio Grande do Sul, Instituto de Arquitetos do Brasil, Sociedade de Engenharia do Rio Grande do Sul, Associação Riograndense de Imprensa, Instituto do Patrimônio Histórico e Artístico Nacional, Instituto do Patrimônio Histórico e Artístico do Estado e Ordem dos Advogados do Brasil.

Esta cidade tem sido alvo de pesquisas arqueológicas sistemáticas desde 1993. Alguns desses sítios foram utilizados no Projeto de Educação Patrimonial, 
implantado pela Coordenação da Memória Cultural, através das Oficinas de Arqueologia, promovendo-se a valorização de sítios históricos ${ }^{68}$.

Em 1997, a arqueóloga Fernanda B. Tocchetto, do Museu Joaquim José Felizardo/Secretaria Municipal de Cultura de Porto Alegre, desenvolveu o Programa de Arqueologia Urbana, orientado pelo conceito de "arqueologia da cidade", definido por Staski como "o estudo das relações entre cultura material, comportamento humano e cognição em um cenário urbano" 69 .

Para Tocchetto (1997: 04), deve-se buscar uma conciliação entre os sítios urbanos históricos e os pré-coloniais e do meio rural, alheios ao processo de constituição do espaço urbano, aplicando-se "estratégias de gestão do patrimônio arqueológico municipal - histórico e pré-histórico - em vista de que ambos estão sujeitos as mesmas interferências antrópicas".

Com o Programa de Arqueologia Urbana, pretendia-se, principalmente, o estabelecimento das zonas de interesse arqueológico e a elaboração de uma legislação específica para a proteção e pesquisa desse patrimônio, considerando as obras de impacto ambiental e as obras privadas e públicas sem impacto ambiental. Buscava-se a proteção dos sítios nessas áreas, através de diretrizes estabelecidas junto às Secretarias Municipais.

\subsection{5 - SÃO JOSÉ DOS CAMPOS / SP}

O município de São José dos Campos possui, desde 1985, legislação específica de proteção ao Patrimônio Cultural. A Lei Municipal no 3.021, de 27 de setembro de 1985, dispõe sobre a criação de Elementos, Setores e Zonas de Preservação, permitindo a preservação de bens móveis e imóveis.

68 PORTO ALEGRE. Secretaria Municipal de Cultura. Educação Patrimonial. Porto Alegre: Coordenação da Memória Cultural, 1997.

69 STASKI, E. Advances in Urban Archaeology. Archaeology of Urban America. London: Academic Press, 1982, p. $41-61$. 
Embora a lei de preservação permita a proteção de bens móveis e imóveis, ela prioriza o patrimônio edificado. A lei contempla as seguintes categorias de preservação:

I. Elemento de preservação - EP, caracterizado como bem móvel ou imóvel de interesse para o Município por seu valor artístico, paisagístico, cultural, etnográfico, arquitetônico, arqueológico ou documental;

II. Setor de Preservação - SP, caracterizado como conjunto de bens imóveis de interesse cultural, artístico, arqueológico, histórico, arquitetônico, paisagístico ou ambiental para o Município;

III. Zona de Preservação - ZP, caracterizada como área que por suas condições paisagísticas, ambientais, arqueológicas ou ecológicas mereçam ser preservadas e conservadas.

A categoria I (Elemento de Preservação) é subdividida em:

EP - 1: São bens móveis ou imóveis que por suas características históricas, artísticas, paisagísticas, culturais, etnográficas, arquitetônicas, arqueológicas e documentais devem ser preservadas totalmente sob a orientação do COMPHAC.

EP - 2: São bens imóveis que por suas características históricas, artísticas, paisagísticas, culturais, arquitetônicas e arqueológicas devem ser preservadas mantendo-se as características básicas de sua arquitetura definidos em cada caso, previamente pelo COMPHAC.

EP - 3: São bens imóveis que suas características históricas, artísticas, paisagísticas, culturais, etnográficas, arquitetônicas e/ou arqueológicas devem ser preservadas ou projetadas de tal modo que mantenham as características do conjunto arquitetônico, urbano, ou paisagístico ao qual pertençam, a partir de diretrizes previamente definidas pelo COMPHAC.

Já o Conselho Municipal de Preservação do Patrimônio Histórico, Artístico, Paisagístico e Cultural (Comphac), órgão criado em 1984 e vinculado à Secretaria Municipal de Planejamento e Meio Ambiente, passou em 2000 a vincular-se à Fundação Cultural "Cassiano Ricardo". O Comphac é responsável pela aplicação da 
Legislação de Patrimônio do Município de São José dos Campos, instituída no ano seguinte.

O Comphac atua como um conselho consultivo sobre a política de patrimônio do Município, composto por representantes da Administração Municipal, Câmara Municipal e sociedade civil, e presidido pelo presidente da Fundação Cultural "Cassiano Ricardo". A subordinação original do Comphac à Secretaria de Planejamento e Meio Ambiente deveu-se à linha preservacionista adotada, que pretendia conciliar preservação do patrimônio cultural com o crescimento planejado do Município.

Apesar da legislação de defesa do patrimônio cultural, pouco foi realizado pelo Poder Público nos primeiros oito anos de sua vigência, devido à ausência de um corpo técnico permanente para prestar assessoria e executar as decisões do Comphac.

Ao criar a Diretoria de Patrimônio Cultural (DPC) ${ }^{70}$, através da Lei 4.455, de 21 de outubro de 1993, a Administração Municipal atribuiu à Fundação Cultural Cassiano Ricardo (FCCR) ${ }^{71}$, entre outras competências, a de "manter equipe especializada para prestar assistência técnica ao Conselho Municipal de Preservação do Patrimônio Histórico, Artístico, Paisagístico e Cultural (Comphac) na promoção da defesa do Patrimônio artístico, histórico e cultural do Município, responsabilizandose pela execução de suas decisões no que diz respeito à política de patrimônio arquitetônico e arqueológico".

A DPC foi regulamentada pela presidência da FCCR ao editar a Portaria No 010/94DPC-FCCR, de 28 de fevereiro de 1994, que estabeleceu a estrutura administrativa e cargos da nova Diretoria da Instituição. A Portaria subordinou à DPC o Arquivo Público do Município (APM) e o Museu Municipal (MM), além de criar o Departamento de Patrimônio Histórico (DPH).

\footnotetext{
${ }^{70}$ A Diretoria de Patrimônio Cultural foi extinta em 1999, ficando o DPH subordinado à Diretoria Cultural da FCCR.

${ }^{71}$ A FCCR é uma Fundação de direito privado mantida pela Prefeitura Municipal de São José dos Campos.
} 
Pela ação do DPH foi possível ampliar o número de edificações protegidas pelo Município e desenvolver uma série de projetos de restauração que foram executados (Capela São Miguel, Câmara Municipal, Biblioteca Pública Municipal Cassiano Ricardo, Mercado Municipal, Igreja São Benedito, etc.). Entretanto, a Arqueologia foi quase sempre utilizada como auxiliar nos trabalhos de restauração de edifícios históricos, ou seja, a chamada "Arqueologia da Restauração". Não foi realizado qualquer trabalho sistemático para a identificação e proteção dos sítios arqueológicos, apesar do potencial da região.

\subsection{6 - SÃO PAULO}

A cidade de São Paulo possui o Departamento de Patrimônio Histórico - DPH, criado em 1983, e o Conselho Municipal de Preservação do Patrimônio Histórico, Cultural e Ambiental da Cidade de São Paulo - Conpresp, desde 1985.

Em 1979, foi elaborado um programa de colaboração entre o Departamento de Patrimônio Histórico (DPH/SMC) e o Museu Paulista (USP) para o restauro de Bens protegidos por lei municipal. Essa experiência resultou, no início da década de 1990, no projeto Levantamento e Cadastro Arqueológico do Município de São Paulo e na inclusão na Lei Orgânica do Município (Art. 197) ${ }^{72}$ da obrigatoriedade de acompanhamento arqueológico das obras no centro histórico. ${ }^{73}$

A arqueóloga Lúcia de Jesus C. O. Juliani, então do DPH, foi a principal responsável pela elaboração da política de gestão arqueológica do município. Suas propostas baseiam-se no conceito de potencial arqueológico, "visando a definição de áreas com probabilidade de ocorrência de vestígios materiais de significância para o conhecimento da ocupação humana do território paulistano" (JULIANI, 2001: 02).

\footnotetext{
${ }^{72}$ Lei Orgânica do Município de São Paulo Artigo 197 - As obras públicas ou particulares que venham a ser realizadas nas áreas do centro histórico de São Paulo e em sítios arqueológicos, nas delimitações e localizações estabelecidas pelo poder público, serão obrigatoriamente submetidas ao acompanhamento e orientação de técnicos especializados do órgão competente.

73 JULIANI, Lúcia de Jesus C. O. Gestão Arqueológica em Metrópoles: uma proposta para São
} Paulo. São Paulo, 1996. Diss. (mestr.) - Universidade de São Paulo, MAE, p. 112. 


\subsection{7 - TAUBATÉ I SP}

O município de Taubaté também possui lei municipal de tombamento. A Lei Complementar $n^{\circ}$ 55/94 dispõe sobre a preservação e proteção do patrimônio cultural do município.

O município inseriu o patrimônio histórico nas políticas públicas municipais em 1976, com a criação da Divisão de Museus, Patrimônio e Arquivo Histórico.

Destacamos a preocupação do legislador com o patrimônio imaterial, somente reconhecido pelo Governo Federal para fins de registro e proteção em 1999. A lei municipal determina que o Conselho Municipal de Preservação do Patrimônio Histórico, Artístico, Urbanístico, Arqueológico e Arquitetônico identificará e protegerá as atividades dos figureiros, do folclore e da música caipira, as festividades populares e a Feira da "Breganha".

O referido conselho municipal é composto por 04 membros do Poder Executivo e 03 da Universidade de Taubaté, uma instituição de autarquia municipal. 


\section{PARTE IV}

\section{ANÁLISE dAs Políticas MunicipaIS ESTUdAdAS}




\section{Parte IV}

\section{ANÁLISE DAS POLÍTICAS MUNICIPAIS ESTUDADAS}

\subsection{Conselhos Municipais de Patrimônio Cultural e leis municipais de tombamento}

Os municípios analisados nos permitem, ainda que por amostragem, visualizar um quadro das ações de preservação do patrimônio no plano municipal. A maioria das cidades estudadas possui leis de tombamento e Conselhos Municipais de Patrimônio. Esses Conselhos diferenciam-se pelas atribuições e, principalmente, pela representatividade. Essa representatividade que, em princípio, garantiria a participação democrática da sociedade nas decisões dos Conselhos, fica, em muitos casos, comprometida pelo número majoritário de representantes do Poder Público. Entretanto, numa avaliação geral dos Conselhos que analisamos, há um certo equilíbrio entre membros das Prefeituras e de associações civis.

Destacamos a participação de membros do Poder Legislativo dos municípios, fato preocupante, haja vista os Conselhos serem órgãos do Poder Executivo, onde não poderia haver a presença de membros do Legislativo.

\section{Proporção dos membros de Conselhos Municipais de Patrimônio}

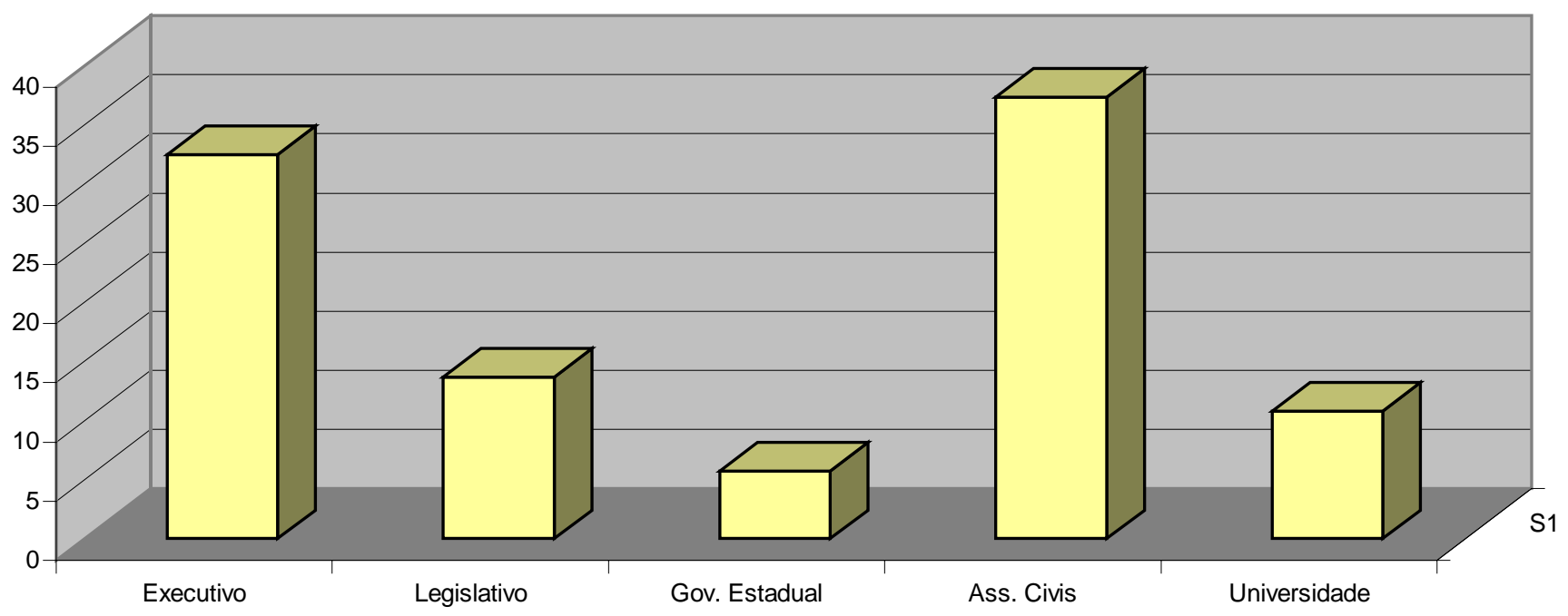


Já a participação de universidades parece um fator positivo, pois disponibilizaria profissionais tecnicamente mais capacitados para avaliar as decisões dos Conselhos.

Outro problema com relação aos Conselhos Municipais de Patrimônio é o seu caráter de ação - Deliberativo ou Consultivo. Pela própria natureza das questões ligadas à preservação do patrimônio cultural, envolvendo interesses políticos e econômicos, e para garantir a execução das decisões dos colegiados, os Conselhos deveriam ser deliberativos.

Infelizmente, a maioria dos Conselhos de Patrimônio ainda é meramente consultiva. Isto permite às Administrações Municipais ignorar as decisões dos Conselhos quando a preservação se contrapõe aos interesses políticos vigentes.
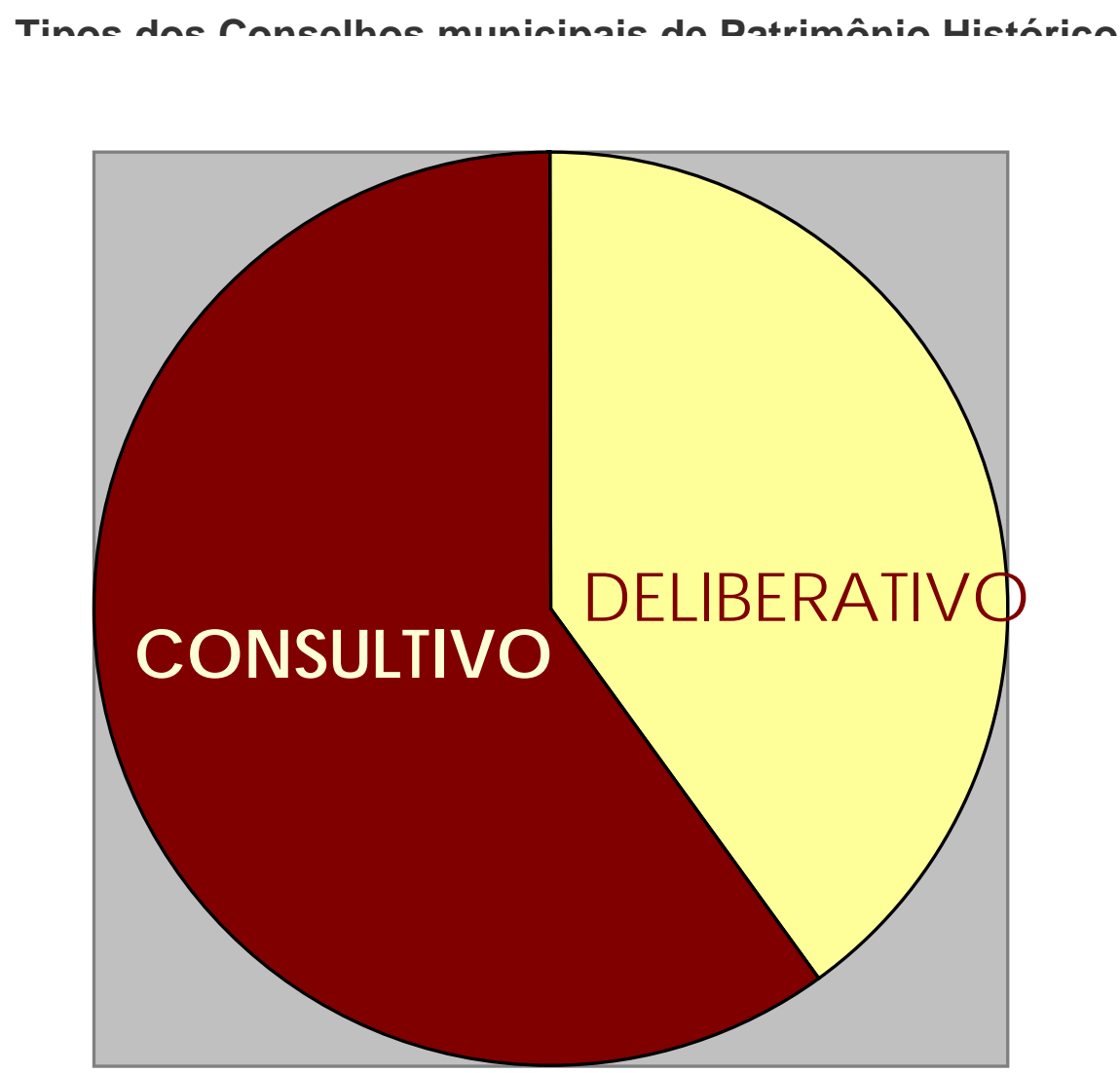
A falta de órgãos de assessoria ou câmaras técnicas é outra dificuldade constatada em vários municípios. Dessa forma, torna-se difícil ao colegiado analisar questões técnicas ou que necessitem de uma avaliação técnica. Nesse sentido, o município de Piraju encontrou uma solução adequada, ao criar uma Câmara Técnica, composta por profissionais da área e desvinculados da Administração Pública. Esses profissionais não são remunerados, o que permite maior liberdade e isenção.

É preciso, pois, refletir sobre o papel desses Conselhos. Um Conselho é uma unidade da Administração Pública Municipal. Mais especificamente, um órgão municipal colegiado que possui funções públicas. Cabe lembrar o que escreveu Hely Lopes Meirelles sobre os órgãos colegiados:

"Os órgãos integram a estrutura do Estado e das demais pessoas jurídicas como partes desses corpos vivos, dotados de vontade e capazes de exercer direitos e contrair obrigações para a consecução de seus fins institucionais. [...] Órgãos colegiados ou pluripessoais são todos aqueles que atuam ou decidem pela manifestação conjunta ou majoritária da vontade de seus membros. Nos órgãos colegiados não prevalece a vontade individual de seu Chefe ou Presidente, nem a de seus integrantes isoladamente: o que se impõe e vale juridicamente é a decisão da maioria, expressa na forma legal, regimental ou estatutária" ${ }^{74}$.

Os Conselhos apresentam a possibilidade de contemplar no processo decisório a opinião de diversos setores da sociedade sobre casos de repercussão ambiental e patrimonial. Isso se baseia no princípio da participação pública na proteção do meio ambiente. Conforme Paulo Affonso Leme Machado, é um princípio "em que as decisões administrativas ambientais passaram das mãos de um só funcionário, ou

\footnotetext{
${ }^{74}$ MEIRELLES, Hely Lopes. Direito Administrativo Brasileiro. São Paulo: Malheiros, 1999, 24. ed., p. 68.
} 
de uma comissão de funcionários públicos, para conselhos, em que a chamada 'sociedade civil' ou as 'organizações não governamentais' tivessem voz e voto" ${ }^{75}$.

Mas, como lembrou o Procurador de Justiça do Ministério Público do Estado de Minas Gerias ao analisar a nomeação irregular de novos membros do Conselho Municipal de Meio Ambiente de Brumadinho ${ }^{76}$, apenas a criação de conselhos e sua sustentação jurídica não garantem o seu desempenho adequado.

\begin{abstract}
"Todavia, é preciso dizer que todo esse arcabouço teóricojurídico não é capaz, por si só, de tornar efetivas as propostas para uma participação democrática na proteção do meio ambiente. Somente sua praxis pode fazê-lo, e, indubitavelmente, isso está a depender, entre outros fatores, dos critérios normativos de escolha dos componentes do órgão colegiado, daqueles que terão por munus deliberar acerca das políticas locais, regionais e nacionais de preservação ambiental".
\end{abstract}

Com relação às leis municipais de tombamento, as diferenças dizem respeito às formas de preservação, à abrangência do conceito de patrimônio cultural, que vai determinar o que será protegido ou não, à existência ou não de incentivos fiscais aos proprietários dos bens tombados, e sua vinculação com uma política municipal.

O patrimônio arqueológico raramente é contemplado nessas leis, e quando aparece, é de forma periférica, nunca estando entre as prioridades. Existem vários fatores que poderiam explicar este fato. Um deles é histórico e cultural, e diz respeito à valorização do patrimônio edificado, além do patrimônio natural. O patrimônio edificado e as ações para sua preservação e restauração sempre figuraram como prioritárias nas políticas de patrimônio nas esferas federal, estaduais e municipais.

\footnotetext{
${ }^{75}$ MACHADO, Paulo Affonso Leme. Direito Ambiental Brasileiro. São Paulo: Malheiros, 2000, 8a . Ed., p. 71.

${ }^{76}$ CAO-MA / MG. Protocolo n ${ }^{\circ}$ 505/2002
} 
Nas três esferas do governo, o patrimônio edificado é assimilado como monumento e símbolo do poder, cuja história deve ser construída considerando as elites, os "vultos", e que, portanto, devem ser preservados.

O patrimônio edificado, mais do que qualquer outro artefato é um "semióforo", que no conceito de Chauí (2000: 12) é:

\begin{abstract}
"um objeto, uma pessoa ou uma instituição retirados do circuito do uso ou sem utilidade direta e imediata na vida cotidiana porque são coisas providas de significação ou de valor simbólico, capazes de relacionar o visível e o invisível, seja no espaço, seja no tempo, (...). É um objeto de celebração (...)".
\end{abstract}

E é através da celebração que se conserva a unidade. A nação produz semióforos nacionais, restaurando o patrimônio edificado e artístico. Mas o patrimônio arqueológico também é um semióforo, também recebendo financiamento para pesquisas arqueológicas. Então porque também não é tratado com a mesma atenção nas políticas de preservação?

Em primeiro lugar a maioria dos sítios arqueológicos não é aparente, visível. A sua promoção sempre é feita através de exposições em Museus e publicações, dois veículos que atingem parcelas diminutas da população.

Em segundo lugar, a história a que nos remete os sítios arqueológicos pré-coloniais é aquela anterior à colonização e que, no Brasil, ao contrário da maioria dos países latino-americanos, a sociedade não se identifica.

Outro fator, e que nos foi explicitamente apresentado por agentes municipais, referese à proteção federal que recebe o patrimônio arqueológico, através da lei 3924/61 e seu respectivo gerenciamento pelo IPHAN. Muitas Prefeituras Municipais, erroneamente, acreditam que o município não tem poderes para atuar e/ou legislar sobre tal patrimônio, por respeito à hierarquia dos poderes. Na realidade, o Poder Público Municipal pode exercer esse papel, como já demonstrado. 


\subsection{Ações Positivas}

Observamos, em alguns municípios, experiências interessantes, como o caso de São Paulo, que conseguiu inserir a preservação do patrimônio arqueológico do centro histórico na Lei Orgânica do Município, criou o projeto Levantamento e Cadastro Arqueológico do Município de São Paulo e desenvolveu um programa visando identificar áreas com potencial arqueológico. Também o caso do município de Porto Alegre, através do Programa de Arqueologia Urbana, em abordagem similar. Já Joinville, que possui um Museu com fortes ações preservacionistas, vem traçando um diagnóstico preciso de seu patrimônio arqueológico, inicialmente com os sambaquis e estendendo-se a outros tipos. Com a ampliação do leque de tipos de sítios e o trabalho baseado no estabelecimento de zoneamento arqueológico, Joinville pode vir a se destacar na gestão do patrimônio arqueológico local. Já Ilhabela, através do Projeto Arqueológico de Ilhabela, em parceria com o Poder local, tem desenvolvido um conjunto de ações na identificação, proteção e promoção de seu patrimônio.

Trabalhos em parceria com universidades também têm apresentado bons resultados. O município de Piraju possui uma das melhores leis de preservação de Patrimônio Cultural. Com a criação do Sistema Municipal de Meio Ambiente e Patrimônio Cultural de Piraju - SISMMAP, o município ganhou instrumentos e estrutura necessária para o controle mais adequado e participativo do patrimônio cultural. Já o patrimônio arqueológico vem sendo amplamente estudado em parceria com a USP, que também possui um Museu e Centro Arqueológico ${ }^{77}$ na cidade. Acreditamos que essa experiência com a USP e a participação efetiva do Prof. Dr. José Luiz de Morais na área foram decisivas para a formulação da política municipal de preservação.

Através de outro tipo de abordagem, temos o exemplo do município de São Caetano/SP. Por meio de parceria com equipe do Museu de Arqueologia e Etnologia da USP, coordenada pela Profa. Dra. Maria Cristina Oliveira Bruno, o município

\footnotetext{
${ }^{77}$ O Centro Regional de Pesquisas Arqueológicas Mário Neme foi criado por convênio firmado entre o Museu Paulista da Universidade de São Paulo e a Prefeitura do Município de Piraju, em 1970. Hoje o Centro está ligado ao Museu de Arqueologia e Etnologia da USP.
} 
buscou resgatar os espaços da história e da cultura, através do projeto Lugares da Memória de São Caetano do Sul, que também prevê trabalhos de Arqueologia Urbana. Esse projeto foi financiado pela FAPESP.

Embora muitas dessas cidades, inclusive as acima citadas, ainda não tenham conseguido implantar completamente seus respectivos projetos na área arqueológica, são referências importantes e apontam caminhos para o desenvolvimento de políticas de gestão do patrimônio arqueológico.

A maioria dessas políticas trabalha com o conceito de potencial arqueológico, com o estabelecimento de zoneamentos específicos. Essa abordagem é sugerida por Juliani (2001), Tocchetto (1997), Caldarelli (1993) ${ }^{78}$, Cazzetta (1992) ${ }^{79}$ e Cali (2001n).

O estabelecimento de áreas de potencial arqueológico e a confecção de Cartas Temáticas de Arqueologia constituem um instrumento que permite ao Poder Público a preservação desse patrimônio e sua inserção no Planejamento Urbano, além de estar disponível à sociedade, construtores etc. Tal estratégia já tem sido aplicada na Holanda ${ }^{80}$, França ${ }^{81}$, Argentina ${ }^{82}$, Estados Unidos ${ }^{83}$, Canadá $^{84}$, Portugal $^{85}$ e outros países.

${ }^{78}$ CALDARELLI, S. B. A Preservação do Patrimônio Cultural em Planejamento Ambiental. Anais do IV Encontro Nacional de Estudos sobre o Meio Ambiente. Cuiabá, 1993.

${ }^{79}$ CAZZETTA, Miriam Arqueologia e Planejamento Urbano. Anais do I Congresso Latino-Americano sobre a Cultura Arquitetônica e Urbanística. Porto Alegre: PMPA/SMC, 1992, pp. 190 - 196.

${ }^{80}$ VERHAGEN, Philip. La carte du potentiel archéologique en Hollande. Une méthode de prediction fondée sur les méthodes de l'arqchéologie et du paisaje. Les Nouvelles de l'Archéologie, 61, 1995, p. 34 - 39.

${ }^{81}$ BLOUET, Vincent el alli. Gestion du patrimoine archéologique: une politique au service de la recherché. Présentation de l'expérience Lorraine. Les Nouvelles de l'Archéologie. Paris, 43, 1991, p. 5 - 9.

${ }^{82}$ Schávelzon, Daniel. El Plano de Potencial Arqueológico de Buenos Aires. Texto apresentado no XI Congresso da Sociedade de Arqueologia Brasileira. Rio de Janeiro, 2001.

${ }^{83}$ UTLEY, R. M. Archaeology and the National Register. Historical Archaeology, VII, 1973, p. $63-67$.

${ }^{84}$ BONA, L. D. Protecting Cultural Resources trought Forest Manegement Panning in Ontario Using Archaeological Predictive Modeling. In: WESTCOTT, K. L.; BRANDON, R. J. (eds.). Pratical Applications of GIS for Archaeologists. A Predictive Modeling Kit. London: Taylor \& Francis, 2000.

${ }^{85}$ MARQUES, Teresa. El concepto de Carta Arqueológica a partir de la experiencia portuguesa. Inventários e Cartas Arqueológicas. Valladohá, 1993. pp. 83 - 86. 
Com relação à criação de lei municipal específica de Arqueologia no Brasil, poucas cidades vislumbraram essa possibilidade.

\subsection{Políticas Municipais de Gestão do Patrimônio Arqueológico}

Entendemos que uma política de gestão do Patrimônio Arqueológico deve estar inserida em políticas de preservação do patrimônio cultural e significa uma série de iniciativas do Poder Público visando identificar, proteger e promover o patrimônio arqueológico, elaborando leis específicas sobre o tema, ordenando o aparelho burocrático responsável por essa política ou criando órgãos técnicos próprios, caso não existam.

Sugerimos alguns princípios que assegurem aos municípios a manutenção de seus interesses na preservação do patrimônio arqueológico. Algumas das propostas a seguir pudemos apresentar no I Seminário dos Conselhos de Patrimônio Cultural, realizado em Itabirito/MG (2001), como sugestão aos municípios participantes do evento.

\subsubsection{Identificação do Patrimônio Arqueológico}

De maneira geral, o patrimônio arqueológico de um município pode ser identificado de duas formas. A maneira mais usual dá-se através da realização de um inventário, no qual um levantamento arqueológico resulta na identificação de uma parcela significativa dos sítios arqueológicos da cidade. Existem várias maneiras de se realizar um inventário arqueológico, sendo que não discutiremos as diferentes metodologias nesse trabalho. É importante lembrar que o inventário dificilmente conseguirá abranger a totalidade dos sítios arqueológicos de um grande território. Assim, o Poder Público Municipal deve estar ciente da possibilidade de novos sítios serem descobertos, devendo acautelar-se de forma a garantir a sua preservação, através de diversos meios, principalmente através de fiscalização em obras de médio e grande porte, ou em áreas de potencial arqueológico.

Isso nos remete a segunda forma de identificação de sítios arqueológicos, ligada a instrumentos de proteção do Poder Público. O estabelecimento de Zonas de 
Interesse Arqueológico pode ser um caminho alternativo interessante para o município garantir a preservação de seu patrimônio arqueológico sem recorrer ao inventário propriamente.

Esse procedimento considera que existem algumas áreas com maior potencial para abrigarem sítios arqueológicos, podendo o Poder Público assegurar a obrigatoriedade de levantamento arqueológico nessas áreas, no caso de qualquer obra, a fim de se certificar da existência ou não de sítios.

Para isso, faz-se necessário um estudo técnico das informações ambientais e geográficas, que são obtidas pela análise das características físicas da região, com a utilização de cartas com curvas de nível em escala adequada. Estuda-se a proximidade de fontes d'água, a orientação de vertentes, declividade do terreno e outros fatores que orientavam os grupos humanos pretéritos na escolha do local para o seu assentamento. Também são realizados estudos de fotos aéreas, através de estereoscopia, complementando as informações cartográficas e buscando-se vestígios visíveis da alteração do ambiente pelo homem, como manchas de terra preta, de cabanas, alicerces de construções, etc. Esses dados, aliados a informações históricas textuais, cartográficas e iconográficas e a informações orais, permitem determinar as áreas favoráveis ao assentamento humano. Imagens de satélite também podem ser utilizadas com o mesmo propósito, desde que com uma metodologia própria.

Esse estudo resultará na confecção de uma Carta Temática com as Zonas de Interesse Arqueológico assinaladas, constituindo um instrumento do Poder Público Municipal na gestão do patrimônio arqueológico e podendo ser integrada ao planejamento urbano, prevenindo a destruição dos testemunhos materiais do passado. 


\subsubsection{Proteção do Patrimônio Arqueológico}

A proteção do patrimônio arqueológico deve ocorrer através de uma série de instrumentos e ações do Poder Público. O inventário e o estabelecimento de Zonas de Interesse Arqueológico já constituem instrumentos de proteção do patrimônio. A promoção do patrimônio arqueológico também contribui para sua preservação, desde que consiga conscientizar as pessoas para sua importância.

Além dessas ações, o município pode criar leis municipais específicas para a proteção do patrimônio arqueológico local, bem como inseri-lo em outras leis municipais, como a Lei de Uso e Ocupação do Solo, no Plano Diretor da cidade ou na própria Lei Orgânica do Município, entre outras, desde que respeitadas a legislação federal e estadual. Ou seja, estabelecimento de norma suplementar.

Nos municípios onde já existem sítios identificados, o setor de fiscalização da Prefeitura, se devidamente orientado, pode fiscalizar esses locais e evitar a destruição desses bens. Na realidade, qualquer cidadão pode ajudar a fazer esse papel. Nesse sentido, é importante que a comunidade local esteja informada. A diferença é que o Poder Público Municipal tem poder de polícia administrativa.

É possível o desenvolvimento de ações de fiscalização e atendimento a denúncias de destruição de sítios arqueológicos em parcerias com outras instâncias, como aquelas ocorridas no município de Ilhabela, envolvendo as Secretarias Municipais da Cultura e do Meio Ambiente; Parque Estadual de Ilhabela - IF/SMA e Polícia Ambiental (2002 e 2003).

Além da fiscalização, o município pode tomar medidas preventivas - informativas, através da notificação dos proprietários de imóveis que possuem sítios arqueológicos, a exemplo do que já vem sendo feito em Ilhabela; além de registrar em vários documentos a existência do sítio naquele imóvel. Por exemplo: incluir o registro do sítio na documentação do imóvel do Setor de Cadastro da Prefeitura; inserir o registro do sítio em qualquer documento do imóvel emitido pela Prefeitura (IPTU, Certidão Negativa de Débitos Imobiliários, etc.). 


\subsubsection{Promoção do Patrimônio}

O patrimônio arqueológico, como qualquer patrimônio cultural, deve ser comunicado e divulgado, utilizando-se diferentes formas. Somente a difusão do conhecimento gerado por esses bens pode conscientizar a população de sua importância e justificar a manutenção das ações preservacionistas.

Essas ações, já incorporadas na Portaria IPHAN 230/02, têm rendido ótimos resultados, quando adequadamente trabalhadas, dentro de programas de Educação Patrimonial.

Ainda nessa área, é importante que o município possua museus ou instituições adequadas para receber a guarda e a comunicação de acervos gerados por pesquisa arqueológica. Embora a orientação do IPHAN e de várias cartas patrimoniais sugira a permanência desses acervos na própria região de origem, é comum ele migrarem para universidades e museus, muitos deles já com problemas de falta de espaço e estrutura para receber mais material.

Longe de sugerirmos espaços desse tipo para cada município, considerando a falta de estrutura, pessoal e condições econômicas das cidades, bastaria a constituição de centros regionais. Instituições que receberiam acervos de cada região. Um bom exemplo disso é o Centro de Arqueologia do MAE/USP existente em Piraju, e que desenvolve projetos na região do Paranapanema e possui em seu acervo artefatos de vários municípios. O mesmo se aplica ao papel desempenhado pelo Museu do Sambaqui, em Joinville - SC. Esse tipo de iniciativa deveria ser incentivada através de parcerias entre os municípios, os estados (Universidades, Ministério Público e outros) e a União (IPHAN). O papel de divulgador desse patrimônio no âmbito regional também pode ser feito por essas instituições regionais sugeridas.

O aproveitamento turístico de sítios arqueológicos também é um caminho que, além de promover a conscientização da sociedade, colabora para o incremento do turismo local, como é o caso do Projeto de Aproveitamento Turístico dos Sítios Arqueológicos de llhabela já citado. 
"este Projeto considera tais Bens como recurso para o desenvolvimento do município, valorizando-os como patrimônio cultural enquanto fator de cidadania e recurso efetivo para o desenvolvimento sustentável das comunidades detentoras deste patrimônio, preparando-os para visitação pública, tornando-se assim, um atrativo diferenciado para o Turismo em Ilhabela." 86

Ou o Projeto de Sinalização das Ruínas do Abarebebê, no município de Peruíbe.

\subsubsection{Estrutura administrativa necessária}

Para o pleno desenvolvimento de uma política de gestão do patrimônio arqueológico, seria importante que o município possuísse um arqueólogo em seus quadros ou dando assessoria, conjuntamente com a seguinte estrutura básica para atuar na área:

a) Conselho Municipal de Patrimônio Cultural

b) Lei Municipal de Arqueologia (pode estar inserida em outras leis)

c) Órgão técnico formado por profissionais de áreas afins treinados (Departamento de Patrimônio Histórico, Setor ou Núcleo de Arqueologia etc.)

d) Museu Municipal (ou similar) dirigido ou assessorado por museólogo.

${ }^{86}$ CALI, Plácido; COSTA, Rafaela de Sá Lopes da. Projeto para aproveitamento turístico de quatro sítios arqueológicos em Ilhabela. Ilhabela: Projeto Arqueológico de Ilhabela, 2003. 


\section{Parte V}

\section{CONSIDERAÇÕES FINAIS}




\section{Parte V \\ CONSIDERAÇÕES FINAIS}

O estudo das ações e políticas de patrimônio implantadas nos municípios revelou, primeiramente, que, embora haja uma quantidade expressiva de municípios com leis de tombamento, conselhos, órgãos e projetos na área, é um número pouco significativo, se analisado na totalidade dos municípios existentes ${ }^{87}$. De fato, poucas cidades têm condições de manter técnicos adequados e compor um Conselho de Patrimônio, seja pela participação diminuta da comunidade, seja pela falta de pessoal com o mínimo conhecimento na área.

Dentre as cidades analisadas há um claro privilégio no trato dos Bens edificados, em detrimento aos demais bens patrimoniais. Dentre eles o patrimônio arqueológico, pouco lembrado nas leis e políticas existentes.

Acreditamos que o estabelecimento de parcerias e programas envolvendo a União (IPHAN), Estados (Universidades e Órgãos ambientais), Municípios, o Poder Judiciário (Ministério Público Federal e Estadual) e a própria sociedade, poderia resultar em significativas e positivas mudanças nesse quadro.

Tal tarefa poderia ser coordenada pelo IPHAN e Ministério Público que, pela esfera de atuação de ambos, conseguiriam um alcance muito maior. A criação de Centros de Arqueologia ou instituições de referência regionais, já mencionadas, atuariam na assessoria a esses órgãos nos casos abrangidos pela sua região. Estes, por sua vez, fariam a ligação com os municípios menores, sem condições de organizar o seu patrimônio.

Nesse sentido, temos, ainda que em outra área, o exemplo do Termo de Cooperação celebrado entre o Ministério Público do Estado de São Paulo e o

${ }^{87}$ O Brasil possui 5.506 municípios, divididos em 26 Estados-membro e o Distrito Federal, de acordo com dados do Instituto Brasileiro de Geografia e Estatística - IBGE. 
Arquivo do Estado de São Paulo ${ }^{88}$. O termo visa à proteção do acervo arquivístico do estado e o fomento à criação de arquivos municipais para a gestão da documentação governamental, conforme estabelece a Constituição Federal ${ }^{89}$ e a Lei de Arquivos $\mathrm{n}^{\circ}$ 8.159/91 ${ }^{90}$. De acordo com o Termo, o Arquivo do Estado é considerado órgão consultivo do Ministério Público na área de arquivos, atuando, quando solicitado, em perícias técnicas. Muitos municípios vêm criando Arquivos Municipais e Sistemas de Arquivo, graças às ações conjuntas resultantes do Termo citado.

Outro exemplo é a Recomendação Conjunta 01/2004 firmada entre o Ministério Público do Estado de Minas Gerais, o IEPHA e o IPHAN (13 ${ }^{\text {a }}$ Superintendência Regional). A mobilização por parte do MP - MG deu-se através do Grupo Especial de Promotores de Justiça de Defesa do Patrimônio Cultural das Cidades Históricas do Estado de Minas Gerais - GEPPC ${ }^{91}$, com o apoio da Promotoria de Justiça de Defesa do Consumidor da Capital e do Procon Estadual-MG.

Os integrantes da Recomendação, preocupados principalmente com o comércio clandestino de bens culturais, consideraram "a necessidade da criação, pelos órgãos responsáveis, de uma política pública que seja claramente voltada para a promoção e defesa do Patrimônio Cultural brasileiro, nela incluída a regulamentação, mediante instrumentos específicos voltados para a gestão do Patrimônio Cultural". Também consideraram "que a integração dos órgãos culturais com o Ministério Público,

\footnotetext{
${ }^{88}$ Termo de Cooperação Técnica, 30 de agosto de 2000, publicado no Diário Oficial do Estado em $1^{\circ}$ de setembro de 2000.

${ }^{89}$ Art. 216, § 2.o: "Cabem à administração pública, na forma da lei, a gestão da documentação governamental e as providências para franquear sua consulta a quantos dela necessitem"

${ }^{90}$ Lei Federal $n^{\circ}$ 8159/91: Dispõe sobre a política nacional de arquivos públicos e privados e dá outras providências

91 O Grupo Especial de Promotores de Justiça de Defesa do Patrimônio Cultural das Cidades Históricas de Minas Gerais (G.E. Cidades Históricas) foi criado pela RESOLUÇÃO No 52/2003. O Grupo Especial é integrado por membros do Ministério Público com atribuições na defesa do patrimônio cultural nas Comarcas de Barão de Cocais, Belo Horizonte, Caeté, Conceição do Mato Dentro, Congonhas, Diamantina, Itabira, Itabirito, Lagoa Santa, Mariana, Minas Novas, Nova Lima, Ouro Branco, Ouro Preto, Piranga, Sabará, Santa Bárbara (Santa Bárbara, Catas Altas e São Gonçalo do Rio Abaixo), Santa Luzia, São João Del-Rei (municípios de São João Del-Rei e Tiradentes) e Serro, dos quais serão escolhidos o seu Coordenador, bem como 02 (dois) Coordenadores Auxiliares
} 
propicia maior agilidade e eficácia na adoção das ações de promoção e defesa do Patrimônio Cultural brasileiro".

Sendo assim, elencaram uma série de medidas conjuntas, como o registro de peças e dos antiquários e outros profissionais do setor, com recomendações para atuação na área, além da fiscalização conjunta. ${ }^{92}$

Atualmente, a falta de apoio aos municípios para a proteção do patrimônio arqueológico é preocupante. Falta o básico, como cartilhas ou manuais orientando o Poder Público e a população sobre esses Bens e seu valor, como proceder no caso de achados fortuitos, quem procurar, divulgação da legislação existente etc.

$\mathrm{Na}$ realidade, se não existe sequer pleno conhecimento da matéria por parte daqueles que trabalham no meio jurídico, que muitas vezes confundem a proteção dos sítios com tombamento, exigem o registro do sítio no IPHAN, o que é desnecessário para sua proteção jurídica, entre outros casos, o que podemos esperar dos agentes das Administrações Municipais e da sociedade em geral.

De volta ao exemplo dos Arquivos, o Centro de Apoio Operacional das Promotorias de Justiça do Meio Ambiente há tempos colocou à disposição dos Membros do Ministério Público e outros interessados um "kit" acerca da implantação de arquivos públicos municipais, contendo modelo de ajustamento de conduta, legislação e manual técnico, que pode ser obtido no site do Centro de Apoio Operacional ${ }^{93}$ ou solicitado por outro meio, caso haja necessidade.

Mas como vimos anteriormente, também há boas iniciativas na gestão do patrimônio arqueológico e, nesses casos, também é preciso apoio e entendimento de seu potencial e limites.

\footnotetext{
${ }^{92} \mathrm{O}$ comércio clandestino de bens culturais tem sido desastroso para o patrimônio cultural do Estado de Minas Gerais, sendo estimado que aproximadamente $60 \%$ do patrimônio de bens móveis das igrejas mineiras foram deslocados da sua origem para acervos particulares e comerciantes de antiguidades. Fonte: GEPPC-MP e IPHAN

${ }^{93}$ http://www.mp.sp.gov.br/caouma/caouma.htm
} 
Um dos problemas recorrentes, e que geraram processos analisados em diferentes instâncias judiciais, principalmente no STF, é a matéria de competência dos municípios na proteção do patrimônio local, bem como seu poder para legislar a respeito.

É fundamental que esta questão da competência esteja clara, pois é a partir dela que os municípios devem organizar a política do patrimônio. Sintetizando o que já foi exposto no Parte II dessa tese, os municípios têm competência comum com os demais entes federativos para proteger o patrimônio cultural e os sítios arqueológicos. ${ }^{94}$ Com relação à competência dos municípios para legislar sobre a matéria, o tema é um dos mais discutidos, pois o artigo 24 da Constituição Federal estabelece que compete concorrentemente à União, aos Estados e ao Distrito Federal (excluindo os municípios) legislar sobre a proteção ao patrimônio histórico e cultural, bem como sobre a responsabilidade por dano a esses bens. ${ }^{95}$

Ocorre que o artigo 30 estabelece competência aos municípios para "legislar sobre assuntos de interesse local" e "suplementar a legislação federal e a estadual no que couber", além de atribuir-lhe o papel de proteger o patrimônio histórico e cultural local.

Art. 30. Compete aos Municípios:

I - legislar sobre assuntos de interesse local;

II - suplementar a legislação federal e a estadual no que couber;

(..)

VIII - promover, no que couber, adequado ordenamento territorial, mediante planejamento e controle do uso, do parcelamento e da ocupação do solo urbano;

${ }^{94}$ Art. 23. É competência comum da União, dos Estados, do Distrito Federal e dos Municípios: (...) III - proteger os documentos, as obras e outros bens de valor histórico, artístico e cultural, os monumentos, as paisagens naturais notáveis e os sítios arqueológicos;

${ }^{95}$ Art. 24. Compete à União, aos Estados e ao Distrito Federal legislar concorrentemente sobre: (...) VII - proteção ao patrimônio histórico, cultural, artístico, turístico e paisagístico; VIII - responsabilidade por dano ao meio ambiente, ao consumidor, a bens e direitos de valor artístico, estético, histórico, turístico e paisagístico; 
IX - promover a proteção do patrimônio histórico-cultural local, observada a legislação e a ação fiscalizadora federal e estadual.

Ora, esse papel atribuído no artigo 30 somente pode ser cumprido mediante a possibilidade do município legislar sobre a matéria, como está expresso no $\S 2^{\circ}$.

Parece-nos exemplar o processo analisado pelo STF sobre a contestação de inconstitucionalidade de tombamento municipal de imóvel no município de Juiz de Fora $^{96}$. A alegação apresentada era que o município não teria competência para legislar na área. No processo, o Min. Carlos Velloso afirmou:

"É verdade que a competência comum inscrita no art. 23, C.F., competência material, não implica, de forma imediata, competência para legislar. No que toca à União, ao Distrito Federal e aos Estados, a competência para legislar sobre a proteção do patrimônio histórico, cultural, artístico, turístico e paisagístico é concorrente (C.F., art. 24, VII). Isso, entretanto, não quer dizer que os Municípios não têm, também, competência para legislar sobre o tema. Essa competência deflui, é certo, da competência material comum (C.F., art. 23, III). Ora, em Estado de Direito, tudo se faz de conformidade com a lei. Se ao município é negado dispor, normativamente, a respeito, resulta inócua a competência material do art. 23, III. O que convém deixar expresso é que os municípios têm competência para legislar sobre assuntos de interesse local (C.F., art. 30, I) e, no que couber, poderão suplementar a legislação federal e estadual (C.F., art. 30, II), no que diz respeito ao interesse local. A legislação suplementar, é sabido, preenche vazios."

${ }_{96}$ Recurso Extraordinário 308399/MG. Relator Min.Carlos Velloso. Data: 14/04/2005. Julgado em 29/03/2005. 
Sobre o mesmo caso, também tratou o Min. Almeida Melo, ainda na instância do Tribunal de Justiça de Minas Gerais ${ }^{97}$ :

“Ora, não há como efetivamente assegurar a proteção a tais bens, ainda que respeitada a legislação federal e estadual, se ao Município não for outorgado poderes para disciplinar, considerando que cada localidade reflete os valores tradicionais de uma população diferenciada, com seus hábitos e culturas próprios.

A tese encontra lastro no fato de o inciso II do mesmo art. 30 atribuir competência legislativa aos Municípios para suplementar a legislação federal e estadual, no que couber.

A expressão 'no que couber' significa que todas as vezes que questões de interesse local forem exclusivas ou predominantes, haverá espaço para a legislação municipal, sem a qual as particularidades da vida da comunidade não serão consideradas, abrindo-se um vácuo entre o Direito e a realidade".

Ou seja, essa competência legislativa dos municípios não está disposta explicitamente na Constituição Federal, mas o texto constitucional deve ser interpretado sob o "Princípio da Unidade da Constituição", pelo qual o intérprete deve procurar atribuir coerência ao sistema, analisando a norma constitucional como parte de um todo ${ }^{98}$. Assim, como salienta o Ministro Velloso já citado, a competência comum inscrita no art. 23, CF, competência material, não implica, de forma imediata, competência para legislar. Mas, esta competência deflui de competência material, para não tornar tal competência inócua.

\footnotetext{
${ }^{97}$ Número do Processo: 000198640-5/00(1). Tribunal de Justiça de Minas Gerais. Relator: Almeida Melo. Data do Acórdão: 21/12/2000. Data da Publicação: 20/02/2001.

${ }^{98}$ ARAÚJO, Luis Alberto D.; NUNES JR. Vidal Serrano. Curso de Direito Constitucional. São Paulo: Saraiva, 2002, 6ª Ed., p. 64.
} 
Assim como esses casos e os demais expostos ao longo deste trabalho, há um grande número de processos julgados e que torna indiscutível essa competência do município, sendo uma jurisprudência consolidada.

Diante da primeira competência na área, que é a de proteger o patrimônio cultural e arqueológico, o município não pode, pois, se omitir. E o conjunto de ações políticas e administrativas para o seu cumprimento é que formará a política de gestão local.

Esse trabalho, com a caracterização geral das políticas municipais de várias cidades, a análise do papel dos entes federativos na matéria, em especial o dos municípios, os caminhos propostos para gestão do patrimônio local e a disponibilização de material documental de referência, espera ter contribuído com a área e instigado arqueólogos a contemplarem tais preocupações em seus projetos e atuações nos municípios. Espera, também, incentivar o meio jurídico para produzir mais reflexões sobre a matéria e, aos órgãos governamentais, para buscar alternativas concretas para proteção e promoção do patrimônio arqueológico e cultural. 
PARTE VI

Documentação Textual Analisada 


\title{
Parte VI
}

DOCUMENTAÇÃO TEXTUAL PESQUISADA

\author{
6.1 - Leis, Decretos e Portarias Municipais
}

\section{ESPÍRITO SANTO}

\section{Vitória}

LEI No $4438 / 97$

Cria o Código Municipal de Meio Ambiente

LEI No $5155 / 00$

Cria o Fundo Municipal de Cultura, e dá outras providências.

DECRETO No $10.243 / 98$

Cria o Programa Integrado de Desenvolvimento Social e Econômico, Urbanização, Embelezamento, Preservação Ambiental e Infra-estrutura Turística e Viária em toda a Orla Marítima do Município de Vitória - Projeto Orla Marítima e dá outras providências.

LEI No $5131 / 97$

Regulamenta o Licenciamento Ambiental, a Avaliação de Impactos Ambientais e o Cadastro Ambiental nos termos da Lei Municipal n. ${ }^{\circ}$ 4.438, de 28 de maio de 1997 Código Municipal de Meio Ambiente de Vitória, e dá outras providências.

LEI N $3644 / 90$

Determina afixação de obras de arte em edifícios. 


\section{Águas Formosas}

LEI N. 946/97

Estabelece normas de proteção do Patrimônio Histórico e Cultural do município de Águas Formosas e institui o Conselho Deliberativo Municipal do Patrimônio Histórico e Cultural.

\section{Além Paraíba}

LEI 009/98

Estabelece a preservação e proteção dos Bens Móveis e Imóveis de interesse histórico, artístico, paisagístico e cultural.

LEI 1350/91

Cria o Conselho Municipal de Cultura

\section{Alvinópolis}

LEI 1498/97

Estabelece normas de proteção do Patrimônio Cultural e institui o Conselho Municipal do Patrimônio Cultural do município de Alvinópolis.

DECRETO 974/97

Cria o Conselho Deliberativo do município de Alvinópolis.

\section{Antonio Dias}

LEI 1242/98

Estabelece normas de proteção do Patrimônio Cultural e institui o Conselho Municipal do Patrimônio Cultural do município de Antonio Dias.

DECRETO 191/98

Nomeia os membros do Conselho Municipal de Patrimônio Cultural de Antonio Dias. 
DECRETO 190/98

Cria o Conselho Deliberativo do município de Antonio Dias.

\section{Araçuaí}

LEI 11/97

Organiza o Patrimônio Cultural do município de Araçuaí.

DECRETO 021/98

Cria o Conselho Deliberativo do município de Araçuaí.

DECRETO 022/98

Nomeia os membros do Conselho Deliberativo do município de Araçuaí.

\section{Arapoã}

LEI 274/98

Institui o Programa de Proteção ao Patrimônio Histórico Cultural do Município de Arapoã, cria o Conselho Municipal de Patrimônio Histórico e Cultural.

DECRETO 112/98

Nomeia os membros do Conselho Municipal de Patrimônio Histórico e Cultural.

\section{Arcos}

LEI 1718/98

Estabelece normas de proteção do Patrimônio Histórico e Cultural do município de Arcos e institui o Conselho Deliberativo Municipal do Patrimônio Histórico e Cultural. DECRETO 1864/98

Cria o Conselho Municipal do Patrimônio Histórico e Cultural do Município de Arcos. 


\section{Arinos}

LEI 743/98

Estabelece a proteção do Patrimônio Histórico e Cultural do município de Arinos e institui o Conselho Deliberativo Municipal do Patrimônio Histórico e Cultural de Arinos.

DECRETO 645/98

Cria o Conselho Municipal do Patrimônio Histórico e Cultural do Município de Arinos.

\section{Augusto de Lima}

DECRETO 001/98

Cria o Conselho Municipal de Patrimônio Histórico e Cultural de Augusto de Lima.

DECRETO 002/98

Nomeia os membros do Conselho Municipal de Patrimônio Histórico e Cultural de Augusto de Lima.

LEI 543/98

Estabelece a proteção do Patrimônio Cultural.

PORTARIA 09/98

Cria a Comissão Técnica de Assessoria ao Conselho Municipal de Patrimônio Histórico e Cultural de Augusto de Lima.

\section{Belo Horizonte}

LEI No $8146 / 00$

Dispõe sobre a estrutura organizacional da administração direta do poder executivo dá outras providências.

LEI No $8137 / 00$

Altera as leis $n^{\circ} 7.165 / 96,7.166 / 96$, ambas de 27 de agosto de 1996 e lei $n^{\circ}$ 7166/96, revoga a lei nº 1.301/66 e dá outras providências. 
LEI 0 DE 21 DE MARÇO DE 1990

LEI ORGÂNICA DO MUNICÍPIO DE BELO HORIZONTE

LEI No 8525/94

Cria o Programa Cultura Murilo MENDES, institui o Fundo Municipal de Incentivo à Cultura - FUMIC.

LEI 3802/84

Organiza a proteção do patrimônio cultural do município de belo horizonte.

DECRETO 5531 DE 17 DE DEZEMBRO DE 1986

Aprova o Regimento Interno do Conselho Deliberativo do Patrimônio Cultural do Município de Belo Horizonte.

DECRETO 6441 DE 21 DE DEZEMBRO DE 1989

Aprova alterações no regimento interno do conselho deliberativo do patrimônio cultural do município de belo horizonte, a que se refere o decreto $n^{\circ} 5531$, de 17 de dezembro DE 1986.

LEI 7165 DE 27 DE AGOSTO DE 1996

Institui o Plano Diretor do Município De Belo Horizonte.

LEI 7430 DE 05 DE JANEIRO DE 1998

Altera a composição do Conselho Deliberativo do Patrimônio Cultural do município de Belo Horizonte.

DECRETO 6460 de 21 de Setembro de 1989

Dispõe Sobre a Composição do Conselho Deliberativo do Patrimônio Cultural do Município.

\section{Varginha}

LEI 2896/97

Estabelece a proteção do Patrimônio Cultural de Varginha. 
Juiz de Fora

LEI No 8525, DE 27 DE AGOSTO DE 1994

Cria o Programa Cultura Murilo MENDES, institui o Fundo Municipal de Incentivo à Cultura - FUMIC.

DECRETO No 5916, DE MAIO DE 1997

Altera regulamento da Lei Municipal no 8525, de 27 /08/94 


\section{Campo Grande}

\section{LEI No $3833 / 00$}

Revoga a lei $n^{0} 3648 / 99$ de 03 de setembro de 1.999, que dispõe sobre 0 tombamento pelo patrimônio histórico e cultural do município de campo grande, do relógio instalado na praça Ari coelho, confluência da av. Afonso pena com a rua 13 de maio e dá outras providências.

LEI No $3810 / 00$

Cria o Conselho Municipal de Proteção ao Patrimônio Histórico de Campo Grande e dá Outras Providências.

\section{LEI ORGÂNICA DO MUNICÍPIO DE CAMPO GRANDE - MS - 1990}

\section{LEI No $3648 / 99$}

Dispõe sobre o tombamento pelo patrimônio histórico e cultural do município de campo grande-ms, do relógio instalado na praça Ari coelho, confluência da av. Afonso pena esquina com rua 13 de maio e dá outras providências.

LEI No $3540 / 98$

Reorganiza o Conselho Municipal de Cultura e dá outras providências.

LEI No $3525 / 98$

Dispõe sobre a proteção do patrimônio histórico, paisagístico e cultural.

\section{LEI No $3523 / 98$}

Dispõe sobre o tombamento da igrejinha de são Benedito, sito à rua Eva Maria de Jesus s/n, no bairro são Benedito, nesta capital, e dá outras providências.

LEI No $3387 / 97$

Dispõe sobre o tombamento do colégio Osvaldo Cruz, sítio histórico localizado na avenida noroeste $n^{\circ} 5.500$ entre a rua 26 de agosto e rua Dr. João rosa pires e dá outras providências.

LEI No $3314 / 96$ 
Dispõe sobre a reorganização estrutural da prefeitura municipal de campo grande, revoga as leis NoS 2.253/85, 2.686/90, 2.952/93 e dá outras providências.

LEI No $3249 / 96$

Dispõe sobre o tombamento do sítio histórico localizado na vila noroeste, estação ferroviária e nas ruas 14 de julho, rua dos ferroviários, travessa Dr. Temístocles e na rua Dr. Ferreira, pertence.

LEI No $1811 / 79$

Estabelece diretriz para a reforma administrativa da prefeitura municipal, dispões sobre seu sistema administrativo e dá outras providências.

\section{PARÁ}

\section{Belém}

LEI No 8106/01

Dispõe sobre a exploração de publicidade e propaganda ao ar livre no município de Belém e dá outras providências.

LEI n ${ }^{\circ} 7.709 / 94$

Dispõe sobre a preservação e proteção do Patrimônio Histórico, Artístico, Ambiental e Cultural do Município de Belém e dá outras providências.

LEI ORGÂNICA DO MUNICÍPIO DE BELÉM - PA/1990

LEI COMPLEMENTAR No 2/99, de 19 de julho de 1999

Lei Complementar de Controle Urbanístico - Dispõe sobre o Parcelamento, Ocupação e Uso do Solo Urbano do Município de Belém e dá outras providências. 


\section{PARANÁ}

\section{Foz de Iguaçu}

\section{LEI No $1500 / 90$}

Dispõe sobre a preservação do patrimônio natural e cultural do município de Foz do Iguaçu e dá outras providências.

LEI No 1224, DE 12 DE JULHO DE 1985

Cria a Fundação Cultural de Foz do Iguaçu, conforme especifica e dá outras providências.

\section{Curitiba}

\section{LEI ORGÂNICA DO MUNICÍPIO DE CURITIBA - 1991}

LEI No 9801/00

Dispõe sobre os instrumentos de política urbana no município de Curitiba.

LEI No $7833 / 1991$

Dispõe sobre a política de proteção, conservação e recuperação do meio ambiente, revoga a lei $n^{\circ} 7447 / 90$, o artigo $3^{\circ}$ da lei $n^{\circ} 5263 / 75$, e dá outras providências.

\section{LEI No 2211/1962}

Autoriza o poder executivo a permitir que a divisão do patrimônio histórico, artístico e cultural do Paraná, da secretaria de educação e cultura, tombe, como monumentos, o bebedouro localizado no centro da praça Coronel Enéas, e a atual pavimentação daquele logradouro.

LEI No 81/1948

Considera o "Paço da Liberdade, à Praça Generoso Marques, parte integrante do Patrimônio Histórico do município de Curitiba".

LEI ORDINÁRIA Nº 3203/1968

Autoriza o poder executivo a criar o departamento do patrimônio e dá outras providências. 


\section{LEI COMPLEMENTAR N 15/1997}

Dispõe sobre o incentivo fiscal para a cultura, cria o Fundo Municipal da Cultura FMC no município de Curitiba, revogando as leis complementares $n^{\circ} 3 / 91,8 / 93,9 / 93$ e dá outras providências.

DECRETO N $1160 / 71$

Dispõe sobre o setor histórico de Curitiba.

\section{Guarapuava}

\section{LEI No $407 / 94$}

Cria órgãos e cargos na estrutura administrativa do município de Guarapuava, e dá outras providências.

LEI No $391 / 93$

Altera a denominação do conselho municipal de preservação do Patrimônio Histórico - COMUPPAH e alínea d do artigo $3^{\circ}$ da lei 285/92, de 11.06.92.

LEI No 285/92.

Cria o Conselho Municipal de Preservação do Patrimônio Histórico de Guarapuava, e revoga a lei $n^{0} 8 / 84$.

LEI No $8 / 84$.

Cria o Conselho de Preservação do Patrimônio Histórico, ligado a Secretaria de Cultura e Esportes e dá outras providências.

\section{RIO GRANDE DO SUL}

\section{Garibaldi}

LEI No 2935/01

Autoriza para fins de tombamento a constituição de Patrimônio Histórico e Cultural do prédio de Adelina Mazzini e herdeiros, e revoga a lei nº 1570/81. 


\section{Blumenau}

\section{LEI ORGÂNICA DO MUNICÍPIO DE BLUMENAU - 1990}

LEI No $5320 / 99$

Transfere saldo de dotação orçamentária e autoriza abertura de crédito especial no orçamento do fundo municipal de conservação do patrimônio histórico e arquitetônico.

LEI No 4695/96

Transfere a suplementa saldo de dotação orçamentária no orçamento do fundo municipal de conservação do patrimônio histórico arquitetônico de Blumenau.

LEI No 4660/96

Transfere parcialmente dotação orçamentária e abre crédito especial no orçamento do fundo municipal de conservação do patrimônio histórico e arquitetônico de Blumenau.

\section{LEI No $4496 / 95$}

Estima a receita e fixa a despesa do fundo municipal de conservação do patrimônio histórico arquitetônico para o exercício financeiro de 1995.

\section{LEI No $4744 / 96$}

Transfere parcialmente dotação orçamentária e abre crédito especial no orçamento do fundo municipal de conservação do patrimônio histórico e arquitetônico de Blumenau.

LEI No 4919/97

Suplementa saldo de dotação orçamentária no orçamento da Fundação Cultural de Blumenau.

\section{LEI 5109/98}

Transfere e suplementa saldos de dotações orçamentárias no orçamento vigente da fundação cultural de Blumenau.

LEI No $5460 / 00$ 
Determina a inclusão do conteúdo "História de Blumenau e vale do Itajaí" no currículo das escolas municipais.

LEI No 5749

Transfere parcialmente e suplementa saldos de dotações orçamentárias no orçamento vigente da fundação cultural de Blumenau.

LEI No 5719

Declara de utilidade pública o "Centro Cultural Germânico Tradições do Vale".

LEI No $5130 / 98$

Dá nova redação ao inciso $v$, do artigo $3^{\circ}$, da lei $n^{\circ} 3853$, que "dá destinação de verba às entidades culturais de tradição folclórica do município".

LEI COMPLEMENTAR N 79/94

Institui o Programa de Proteção e Valorização do Patrimônio Histórico arquitetônico do município e dá outras providências.

LEI 3142/84

Concede isenção fiscal às edificações de valor histórico e arquitetônico existentes no município de Blumenau.

LEI N² $2449 / 79$

Dispõe sobre a proteção do patrimônio histórico e cultural do Município de Blumenau.

\section{Brusque}

LEI ORGÂNICA DO MUNICÍPIO DE BRUSQUE - 1990

\section{Capivari de Baixo}

LEI No $517 / 99$

Dispõe sobre a proteção do patrimônio histórico, artístico e natural do município e dá outras providências. 
LEI No $627 / 2000$

Revoga o art. 28 da lei $n^{\circ}$ 517/99, de 20 de outubro de 1999, anulando o tombamento da casa da cultura.

\section{Criciúma}

LEI No $3700 / 98$

Dispõe sobre a proteção do patrimônio histórico, artístico e natural do município, revoga a lei 2063/85, e dá outras providências.

\section{Bombinhas}

LEI No $614 / 01$.

Dispõe sobre a preservação do patrimônio natural e cultural do município de bombinhas, e dá outras providências.

LEI No $489 / 99$

Concede auxilio financeiro ao Instituto Boimamão de preservação do patrimônio histórico e cultural do município de Bombinhas.

LEI No $467 / 99$

Declara de utilidade pública o Instituto Boimamão de preservação do patrimônio histórico e cultural do município de Bombinhas.

\section{Curitibanos}

\section{LEI No $1815 / 88$}

Tomba bens móveis e incorpora ao patrimônio histórico e cultural do município de curitibanos, e dá outras providências.

LEI No $1705 / 87$

Tomba bens imóveis e incorpora ao patrimônio histórico e cultural do município de curitibanos e dá outras providências. 


\section{Florianópolis}

LEI No 1.202/74

Dispõe sobre a proteção de seu patrimônio e instituiu o instrumento do tombamento (preservação com proteção legal).

LEI No $2.193 / 85$

Institui o Plano Diretor dos Balneários

LEI N. 2183/95

Cria as Áreas de Preservação Cultural

DECRETO MUNICIPAL No 270/86

Tomba dez conjuntos urbanos no centro da cidade

DECRETO MUNICIPAL NN 521/89

Classifica os conjuntos históricos tombados em três níveis de proteção

LEI COMPLEMENTAR 001/97

Cria a Área de Preservação Cultural da Área Central

LEI MUNICIPAL No 2.193/85

Cria a Área de Preservação Cultural de Canasvieiras

LEI MUNICIPAL No 2.193/85

Cria a Área de Preservação Cultural de Costa da Lagoa

LEI MUNICIPAL No 2.193/85

Cria a Área de Preservação Cultural de Lagoa da Conceição

LEI MUNICIPAL No 2.193/85

Cria a Área de Preservação Cultural de Ribeirão da llha

LEI MUNICIPAL No 2.193/85

Cria a Área de Preservação Cultural de Santo Antônio de Lisboa

LEI MUNICIPAL No 2.193/85

Cria a Área de Preservação Cultural de São José da Ponta Grossa 
DECRETO MUNICIPAL N. ${ }^{\circ} 190 / 90$

Preserva parte da estrutura urbana colonial de Florianópolis, em uma área que foi objeto de generalizada substituição da arquitetura definidora do conjunto original.

LEI COMPLEMENTAR N. ${ }^{\circ}$ 001/97

Cria o Plano Diretor do Distrito Sede

\section{Gravatal}

LEI No 844/00 DE 29 DE AGOSTO DE 2000.

Dispõe sobre a preservação do patrimônio natural, cultural, e institui o Fundo de Proteção do Patrimônio Natural e Cultural de Gravatal

\section{Icara}

\section{LEI No $553 / 84$}

Dispõe sobre a proteção do patrimônio histórico, artístico e natural do município de Içara e cria órgão competente.

\section{Imbituba}

\section{LEI No $1762 / 98$}

Dispõe sobre a constituição e preservação do patrimônio natural e cultural do município de Imbituba, cria o Conselho municipal do patrimônio cultural e institui reserva de contingências".

\section{Itajaí}

LEI ORGÂNICA DO MUNICÍPIO DE ITAJAÍ - 1990

LEI No $3198 / 97$

Cria o Conselho Municipal do Patrimônio Cultural de Itajaí, e dá outras providências. LEI No 3240, DE 26 DE DEZEMBRO DE 1997 
Cria a Fundação Cultural de Itajaí, e dá outras providências.

LEI No $3249 / 98$

Estima a receita e fixa a despesa da Fundação Cultural de Itajaí, para o exercício financeiro de 1998.

\section{Jaraguá do Sul}

\section{LEI No $1854 / 94$}

Dispõe sobre a proteção do patrimônio histórico, cultural, arqueológico, artístico e natural do município de Jaraguá do Sul.

\section{Joinville}

LEI No $4463 / 01$

Autoriza o executivo municipal, por intermédio da Fundação Cultural de Joinville, a celebrar o convênio nº 032/2001, de cooperação mútua com a união federal, através do ministério da cultura.

LEI No $4427 / 01$

Autoriza o executivo municipal, por intermédio da Fundação Cultural de Joinville, a celebrar convênio com a união federal, através do Ministério da Cultura.

LEI No 4417/01

Altera a lei no 3.333/96 de 22.07.96, que dá nova estrutura à Fundação Cultural de Joinville e dá outras providências.

LEI n' $4204 / 00$

Autoriza o executivo municipal, por intermédio da Fundação Cultural de Joinville, a celebrar convênio com a união federal, através do Ministério da Cultura.

Lei $n^{\circ} 4203$, de 21 de julho de 2000

Autoriza o executivo municipal, por intermédio da Fundação Cultural de Joinville, a celebrar convênio com a união federal, através do Ministério da Cultura.

PORTARIA N 50/97 
Altera o Regimento Interno do Museu Arqueológico de Sambaqui de Joinville.

\section{LEI 1774/80}

Estabelece imunidade e isenções tributárias no Município de Joinville e dá outras providências.

LEI $1773 / 80$

Dispõe sobre a proteção do Patrimônio Histórico, Arqueológico, Artístico e Natural do Município de Joinville.

LEI N $1772 / 80$

Altera o Art. 17 da Lei $n^{\circ}$ 1514/77.

\section{Lages}

LEI ORGÂNICA DO MUNICÍPIO DE LAGES - 2000

LEI COMPLEMENTAR N. ${ }^{\circ} 130 / 00$

Cria a Unidade Territorial Exclusiva de Preservação Permanente.

LEI COMPLEMENTAR Nº 085/97

Dá nova redação, revoga e acrescenta artigos na lei complementar $n^{\circ} 024$ de 27.10.95, que criou a Fundação Cultural de Lages.

\section{Laguna}

LEI N 49/77

Dispõe sobre Loteamentos e dá outras providências.

LEI N $34 / 77$

Dispõe sobre a Proteção do Patrimônio Histórico, Artístico e Natural do Município.

LEI N 37/78

Altera Dispositivos da Lei de Loteamentos n 49/77.

LEI N 42/78

Dispõe sobre o Código de Posturas Municipal de Laguna e dá outras providências.

LEI N 43/78 
Dispõe sobre Código de Obras do Município de Laguna.

LEI N 04/79

Dispõe sobre Zoneamento de Uso do Solo e dá outras providências.

LEI N 31/80

Dispõe sobre os projetos de Arruamentos e dá outras providências.

LEI N 271/93

Cria a Fundação de Cultura.

LEI N 467/96

Cria a Fundação Lagunense de Cultura e dá outras providências.

LEI N 510/97

Cria o Conselho Municipal de Turismo e dá outras providências.

LEI N 511/97

Cria o Fundo Municipal de Turismo.

LEI COMPLEMENTAR N 033/97

Art. 19 / Item VII - Estabelece incentivo fiscal regulamentando percentuais variáveis de isenção do Imposto Predial para imóveis tombados pelo IPHAN.

DECRETO N 17/78

Tombamento de conjuntos do centro histórico.

DECRETO N 17/78

Tombamento de Edificações isoladas.

LEI ORGÂNICA DO MUNICÍPIO - 2000

\section{Palhoça}

LEI No $619 / 97$

Dispõe sobre proteção do patrimônio histórico, cultural artístico e natural do município e cria órgão competente.

\section{Santo Amaro da Imperatriz}

LEI No 854 de 19 de abril de 1991 
Altera dispositivos da lei 478/80, que dispõe sobre a proteção do patrimônio histórico, artístico e natural do município e cria órgão competente.

LEI N 478 DE $1^{\circ}$ DE DEZEMBRO DE 1980

Dispõe sobre a proteção do patrimônio histórico, artístico e natural do município e cria órgão competente.

\section{São Francisco do Sul}

LEI MUNICIPAL N 756/81

Cria uma Zona Especial de Proteção e seu disciplicamento; estabelece benefícios e incentivos fiscais; institui o tombamento de bens naturais pelo município e dá atribuições ao departamento de educação cultura e turismo e ao Conselho Municipal de Cultura.

LEI MUNICIPAL No 763/81

Dispõe sobre o zoneamento do município de São Francisco do Sul, estado de Santa Catarina.

\section{Rio do Sul}

LEI COMPLEMENTAR Nº 031/98.

Altera dispositivos da lei complementar $n^{\circ}$ 027/97, que dispõe sobre a proteção do patrimônio histórico-cultural, natural e paisagístico do município de Rio do Sul.

LEI COMPLEMENTAR N027/97

Dispõe sobre a proteção do patrimônio histórico-cultural, natural e paisagístico do município de rio do sul, cria fundo, institui incentivos e dá outras providencias.

\section{São José}

LEI No $3752 / 01$.

Dispõe sobre a proteção do patrimônio histórico, artístico e natural do município, cria o órgão competente e dá outras providências. 
Lei $n^{\circ} 3024 / 97$

Cria o museu histórico municipal de São José, e dá outras providências.

\section{Tubarão}

LEI No 2229/99, DE 18 DE JANEIRO DE 1999.

Cria o fundo e o conselho municipais de cultura.

\section{SÃO PAULO}

\section{Guarulhos}

LEI No $5770 / 02$

Cria a Comissão Especial para Revitalização do Centro de Guarulhos e dá providências correlatas

LEI No $4818 / 96$

Estabelece o zoneamento do município, revoga as leis n 3733/90 e 3999/91, e dá outras providências.

LEI No $5702 / 01$

Dispõe sobre as diretrizes orçamentárias para o exercício financeiro do ano de 2002.

LEI N ${ }^{\circ} 4730 / 95$

Dá nova redação ao Artigo $5^{\circ}$ da Lei Municipal n 3618, de 29 de maio de 1990.

LEI 3618/90

Autoriza do Executivo a promover o inventário de bens imóveis de interesse cultural e dá outras providências.

\section{Indaiatuba}

LEI 3328/96

Institui o Conselho Municipal de Preservação 


\section{Ilhabela}

LEI 498/93

Lei Orgânica do Município de Ilhabela

LEI 957/00

Altera a redação do artigo 18 e 35 da Lei Orgânica do Município de Ilhabela

DECRETO 2091/00

Aprova o Regimento interno do Instituto Histórico, Geográfico e Arqueológico de Ilhabela

\section{Campinas}

LEI N $5515 / 84$

Dispõe sobre o Conselho de Defesa do Meio Ambiente (CODEMA).

LEI N ${ }^{\circ} 5885 / 87$

Dispõe sobre a proteção e preservação do patrimônio histórico, artístico, estético, arquitetônico, arqueológico, documental e ambiental do município de Campinas e dá outras providências.

DECRETO N $9546 / 88$

Aprova o regimento interno do Conselho de Defesa do Patrimônio Cultural de Campinas - CONDEPACC.

DECRETO N 9534/88

Dispõe sobre o recebimento de pedidos de abertura de processo de tombamento e aprovação de projetos de intervenção em bens tombados e em áreas envoltórias.

\section{Mauá}

DECRETO N 5824/98 
Dispõe sobre a competência, organização e funcionamento do Conselho de Defesa do Patrimônio Histórico, Artístico, Arqueológico e Turístico.

\section{Peruíbe}

\section{LEI No 2517/04}

Dispõe sobre A Proteção do Patrimônio Histórico, Artístico e Cultural do Município, cria o Conselho de Defesa do Patrimônio Histórico e Cultural de Peruíbe Condepahpe e dá outras providências.

\section{Piraju}

\section{LEI No $1752 / 92$}

Dispõe sobre a criação do Conselho Municipal do Meio Ambiente e do Patrimônio Cultural do Município de Piraju.

LEI No $1855 / 93$

Dispõe sobre o Processo de Tombamento e Bens Culturais, Ambientais e Paisagísticos do Município de Piraju.

LEI N $1854 / 93$

Dispõe sobre a criação do cadastro de Entidades não Governamentais ligadas às atividades ambientais, de ação social, filantrópicas e culturais.

\section{Santos}

LEI MUNICIPAL N 103/85

Dispõe sobre a Proteção do Patrimônio Histórico e Cultural do Município de Santos.

DECRETO MUNICIPAL N³36/86

Dispõe sobre o Conselho Municipal de Cultura

PORTARIA MUNICIPAL N $16 / 86$ 
Designa membros para o Conselho Municipal de Cultura, Artes, História e Patrimônio Cultural, Folclore e Artesanato; e Comissão Distrital de Bertioga.

DECRETO MUNICIPAL N³59/86

Aprova o regulamento de Proteção do Patrimônio Histórico e Cultural do Município de Santos.

\section{São Paulo}

Lei No 10.032/85

Cria o Conselho Municipal de Preservação do Patrimônio - Compresp

\section{Taubaté}

\section{LEI COMPLEMENTAR Nº55/94}

Dispõe sobre a preservação e proteção do patrimônio histórico, artístico, arqueológico, paleontológico, ecológico, arquitetônico e paisagístico do Município, incluindo a composição, organização e competência do Conselho Municipal de Preservação e os procedimentos necessários ao tombamento de bens de natureza material. 


\section{2 - LEIS, DECRETOS E PORTARIAS ESTADUAIS}

\section{Minas Gerais}

\section{DECRETO 42505/02}

Institui as formas de Registros de Bens Culturais de Natureza Imaterial ou Intangível que constituem patrimônio cultural de Minas Gerais.

\section{LEI $13464 / 00$}

Cria o Fundo Estadual de Recuperação do Patrimônio Histórico, Artístico e Arquitetônico - FUNPAT - e dá outras providências.

\section{LEI $13803 / 00$}

Dispõe sobre a distribuição da parcela de receita do produto da arrecadação do ICMS pertencente aos municípios, de que trata o inciso II do parágrafo único do artigo 158 da Constituição Federal.

\section{LEI No $5.775 / 71$}

Autoriza o Poder Executivo a instituir, sob forma de Fundação, o Instituto Estadual do Patrimônio Histórico e Artístico de Minas Gerais (IEPHA/MG).

DECRETO No $14.260 / 72$

Institui, sob forma de Fundação, o Instituto Estadual do Patrimônio Histórico e Artístico de Minas Gerais (IEPHA/MG).

\section{DECRETO No $14.366 / 72$}

Aprova modificações no Estatuto do Instituto Estadual do Patrimônio Histórico e Artístico de Minas Gerais (IEPHA/MG), a que se refere o Decreto $n^{\circ} 14.260$, de 14 de janeiro de 1972.

DECRETO No $14.374 / 72$

Incorpora ao Estatuto do Instituto Estadual do Patrimônio Histórico e Artístico de Minas Gerais (IEPHA/MG) as disposições do Decreto no 14.366, de 07 de março de 1972.

DECRETO n $16.955 / 75$ 
Altera disposições do Estatuto do Instituto Estadual do Patrimônio Histórico e Artístico de Minas Gerais (IEPHA/MG), aprovado pelo decreto $n^{\circ} 14.374$, de 10 de março de 1971.

LEI no 8.828/85

Altera dispositivos da Lei $n^{\circ} 5.755$, de 30 de setembro de 1971, que autoriza o Poder Executivo a instituir, sob forma de Fundação, o Instituto Estadual do Patrimônio Histórico e Artístico de Minas Gerais (IEPHA/MG).

DECRETO n 26.193/86

Aprova o Estatuto do Instituto Estadual do Patrimônio Histórico e Artístico de Minas Gerais (IEPHA/MG).

DECRETO n² 29.243/89

Dispõe sobre a prestação de serviços pelo Instituto Estadual do Patrimônio Histórico e Artístico de Minas Gerais (IEPHA/MG) a órgãos e entidades da Administração Estadual.

\section{LEI $n^{\circ} 11.258 / 93$}

Reorganiza o Instituto Estadual do Patrimônio Histórico e Artístico de Minas Gerais (IEPHA/MG).

Lei Estadual n 11.726/94

Dispõe sobre a Política Cultural do Estado de Minas Gerais, determinando a obrigatoriedade do acompanhamento e documentação, pelo IEPHA/MG, de todas as etapas de intervenções em bens tombados. 


\section{Santa Catarina}

\section{LEI N ${ }^{\circ} 228 / 55$}

Dispõe sobre a proteção dos sambaquis e institui o cadastro dos sambaquis do litoral catarinense.

LEI N $5793 / 80$

Dispõe sobre a proteção dos sítios arqueológicos do Estado de Santa Catarina.

Constituição do Estado de Santa Catarina - 1989.

\section{São Paulo}

RESOLUÇÃO SMA - 34, DE 27-8-2003

Dispõe sobre as medidas necessárias à proteção do patrimônio arqueológico e préhistórico quando do licenciamento ambiental de empreendimentos e atividades potencialmente causadores de significativo impacto ambiental, sujeitos à apresentação de EIA/RIMA, e dá providências correlatas

\section{ORDEM DE SERVIÇO 03/94}

Estabelece critérios para valoração mobiliária de danos causados a bens de valor cultural.

(Publicado no D.O.E. de 15 de dezembro de 1994, Seção I, p. 27) 


\section{3 - PROJETOS, RELATÓRIOS, DELIBERAÇÕES E REGIMENTOS}

- Deliberação normativa do Conselho Curador do IEPHA/MG para o Exercício de 2003.

- Deliberação IEPHA ñ 01/01.

Define os critérios de pontuação previstos no Anexo III da Lei 13.803/00 para o exercício de 2003.

- Diagnóstico Arqueológico e Paleoambiental como Subsídio ao Zoneamento e Conservação do Complexo Arqueológico Caieira: Lagoa do Saguaçu, Joinville/SC. Relatório Final. Joinville: MASJ, 2001.

- Plano Diretor e Plano de Metas. Período: Junho/1998 a Abril/1999. MASJ, 1998.

- Plano de restauração e utilização social e econômica do patrimônio cultural, histórico, artístico, paisagístico e arquitetônico da Laguna. Prefeitura Municipal de Laguna, 1978 - 1980.

- Projeto de Atendimento ao Público de Educação Infantil. Joinville, MASJ, 2000.

- Projeto Museu-Percurso: Intervenção Urbana conta a História de Laguna. Autora: Ivana Lucy Szczuk. Laguna, 2001.

- Projeto Sistema Integrado de Museus de Laguna. Prefeitura Municipal de Laguna/IPHAN - 11 ${ }^{\circ} \mathrm{SR}, 2001$.

- Programa de Comunicação Museológica. Linha: atendimento ao ensino formal. Projeto de Atendimento Educativo $2^{\circ}, 3^{\circ}$ e $4^{\circ}$ ciclos. Joinville: MASJ, 2000.

- Programa da Oficina de Patrimônio Cultural. Autor: Plácido Cali. Prefeitura Municipal de Peruíbe, 1999.

- Regimento Interno do Museu Arqueológico de Sambaqui de Joinville (MASJ) - 1996. 
- Regulamento de Proteção do Patrimônio Histórico e Cultural do Município de Santos. Santos, 1986.

- Relatório 1972 - 1997. Museu Arqueológico de Sambaqui de Joinville. MASJ, 1997.

- Relatório de Projetos em andamento. MASJ, 2001.

\section{4 - LEIS, DECRETOS E PORTARIAS FEDERAIS}

- Lei Federal 3924/61

- Estatuto do Índio, criado pela Lei 6001/73

- Constituição Federal de 1988

- Portaria IPHAN 07/88

- Portaria IPHAN 230/2002

- Portaria IPHAN 28/2003

- Portaria 108/DPC - 2003

- Portaria SPHAN 11/86

- Lei 10257/01 (Estatuto da Cidade).

\section{5 - RESOLUÇÕES, CARTAS E LEIS INTERNACIONAIS}

Convenção Européia para a Proteção do Patrimônio Arqueológico (Revista) - 1992.

Decreto-Lei n. 117/97 - Ministério da Cultura de Portugal

Aprova o regimento do Instituto Português de Arqueologia

Decreto Regulamentar n. 28/97 - Portugal

Estabelece o estatuto das carreiras de pessoal da área funcional de arqueologia. 


\section{6 - RELAÇÃO DE PROCESSOS JUDICIAIS PESQUISADOS}

\subsubsection{Superior Tribunal Federal}

Ação Direta de Inconstitucionalidade n. 2544-9 Rio Grande do Sul

$12 / 06 / 02$

Requerente: Governo do Estado do Rio Grande do Sul

Requerida: Assembléia Legislativa do Estado do Rio Grande do Sul

Resumo: Ação de inconstitucionalidade contra a Lei Estadual 11.380/99, de iniciativa parlamentar que delega, exclusivamente, aos municípios a proteção e a guarda dos sítios arqueológicos e acervos em seus territórios.

\begin{tabular}{|l|l|}
\hline \multicolumn{1}{|c|}{ Agravo de Instrumento n. 109.798-1 } & 26/02/88 \\
\hline Agraventes: João Antonio Ramon e outros & \\
\hline Agravados: Moysés W. Lupin de Troya e Estado do Paraná & $\begin{array}{l}\text { Resumo: Ação proposta visando a nulidade do ato de tombamento feito pelo Estado } \\
\text { do Paraná }\end{array}$ \\
\hline
\end{tabular}

\begin{tabular}{|l|c|}
\hline \multicolumn{1}{|c|}{ Agravo em Agravo de Instrumento n. 235.891-7 DF } & 08/08/00 \\
\hline Agraventes: Distrito Federal & Agravada: Belita Menezes Benther \\
\hline Resumo: Desrespeito ao ato de Tombamento efetuado pelo Distrito Federal \\
\hline
\end{tabular}

\begin{tabular}{|l|l|}
\hline \multicolumn{1}{|c|}{ Hábeas Corpus n. 73.499-9 RS } & 02/04/96 \\
\hline Coator: Tribunal de Justiça de RS & \\
\hline Impetrado: Pedro Jaime Trevisan & \\
Resumo: Crime por colocar em risco patrimônio histórico e cultural nacional, ao \\
manifestar desinteresse do município no tombamento do extinto Hotel Ponche \\
Verde, no município Dom Pedrito/RS, autorizando a sua demolição. Crime conforme \\
art. 165 do Código Penal.
\end{tabular}


Requerente: Paulo Soares de Gouvêa e outros

Agravada:

Resumo: Desapropriação de imóveis tombados pelo IPHAN no município de Vassouras/RJ

Recurso Extraordinário n. 308.399 MG

$29 / 03 / 2005$

Requerente: Marcy D. Ibrahim e outros

Requerido: Município de Juiz de Fora

Resumo: Pedido de inconstitucionalidade da lei de tombamento municipal

Recurso Extraordinário n. 259.267 SP

$13 / 03 / 02$

Requerente: Estado de São Paulo

Reuqeridos: Hélio Brunoro e conjuge

Resumo: Recurso a proibição para desmatamento de gleba localizada em região de Mata Atlântica pelo Governo do Estado de São Paulo, por entender violação do art. 23 da CF, sobre competência dos entes federativos.

Recurso Extraordinário n. 38.663 DF

$14 / 08 / 58$

Recorrente: União Federal

Recorrida: Maria José Campos Seabra

Resumo: Ação para impedir uma construção junto a igreja da Glória do Outeiro, alegando-se prejuízo ao referido patrimônio tombado. 


\begin{tabular}{|l|l|}
\hline \multicolumn{1}{|c|}{ Recurso Extraordinário n. 41.279 DF } & $10 / 07 / 59$ \\
\hline Recorrente: União Federal & \\
\hline Recorrida: Manoel Mendes Campos & $\begin{array}{l}\text { Resumo: Ação para obter a demolição dos quatro últimos pavimentos do "Edifício } \\
\text { Mempos" junto a igreja da Glória do Outeiro, alegando-se prejuízo ao referido } \\
\text { patrimônio tombado. }\end{array}$ \\
\hline
\end{tabular}

\begin{tabular}{|l|c|}
\hline \multicolumn{1}{|c|}{ Recurso Extraordinário n. 61.311 SP } & 07/03/69 \\
\hline Recorrente: Fazenda do Estado & \\
\hline Recorrida: Roberto Guerra de Andrade e outros & $\begin{array}{l}\text { Resumo: Recurso contra desapropriação de imóvel pelo seu valor histórico, } \\
\text { conforme a Lei Estadual 8232/64, visando transformá-lo no "Museu Brigadeiro José } \\
\text { Vieira Couto de Magalhães". A demolição já havia sido iniciada, quando da ação. }\end{array}$ \\
\hline
\end{tabular}

\begin{tabular}{|l|c|}
\hline \multicolumn{1}{|c|}{ Recurso Extraordinário n. 90.581-2 RJ } & 07/08/79 \\
\hline Recorrente: Prefeitura Municipal de Nova Iguaçu & \\
\hline Recorrida: Giacomo Gavazzi (espólio de) & \\
\hline Resumo: Recurso contra desapropriação de imóvel com bem tombado. \\
\hline
\end{tabular}

Recurso Extraordinário n. 104.606-6 RJ

$22 / 03 / 85$

Recorrente: Parati Desenvolvimento Turístico S. A.

Recorridos: Roberto L. de S. Barros e União Federal

Resumo: Recurso contra a autorização dada pelo Ministério de Minas e Energia para empresa empeender pesquisa mineral no município de Parati/RJ, em zona urbana edificada e sem anuência de entidades federais, como o então SPHAN (hoje IPHAN), já que se insere em cidade que é patrimônio nacional. 
Recorrente: Edgar Linhares Filho e sua mulher

Recorrida: Prefeitura Municipal de Curitiba

Resumo: Recurso contra negativa por parte da Prefeitura Municipal em autorizar a demolição de prédio de interesse histórico e cultural.

Recurso Extraordinário n. 121.140-7 RJ

$26 / 02 / 02$

Recorrente: Prefeitura Municipal do Rio de Janeiro

Recorrido: Daniel Miguel Klabin

Resumo: Recurso da Prefeitura Municipal contra acórdão do Quarto Grupo de Câmara do Tribunal de Justiça do Estado do Rio de Janeiro que concedeu a exclusão do rol de Bens tombados pelo município por julgar o tombamento "limitação administrativa genérica, gratuita e unilateral ao exercício do direito de propriedade, em prol da memória da Cidade".

\begin{tabular}{|l|l|}
\hline \multicolumn{1}{|c|}{ Recurso Extraordinário n. 168.917-0 RJ } \\
\hline Recorrente: Espólio de Giácomo Gavazzi \\
\hline Recorrida: União Federal, Fundação Pró-Memória e Município de Nova Iguaçu \\
\hline $\begin{array}{l}\text { Resumo: Ação contra a Prefeitura Municipal de Nova Iguaçu e União Federal por } \\
\text { perdas e danos e restauração do imóvel desapropriado. O imóvel em questão era } \\
\text { tombado pela União e foi desapropriado pela Prefeitura Municipal. Esta, entretanto, } \\
\text { nunca tomou posse do imóvel e, anos depois, sem indenização, desistiu da } \\
\text { desapropriação. Nesse tempo, o imóvel ficou deteriorado. }\end{array}$ \\
\hline
\end{tabular}

Recurso Extraordinário n. 182.782-3 RJ

$14 / 11 / 95$

Recorrente: União Federal

Recorrida: Maria da Glória Mallet de S. A. Nina Ribeiro e outro

Resumo: Questionamento de tombamento de imóvel na cidade do Rio de Janeiro 


\begin{tabular}{|l|c|}
\hline \multicolumn{1}{|c|}{ Recurso Extraordinário n. 208.790-4 } & $27 / 09 / 00$ \\
\hline Recorrente: Álvaro José de Moraes & \\
\hline Recorrida: Ministério Publico Federal & $\begin{array}{l}\text { Resumo: Contestação sobre o papel do Ministério Público na defesa do Patrimônio } \\
\text { Público }\end{array}$ \\
\hline
\end{tabular}

Recurso Extraordinário n. 219.292-1 MG

07/12/99

Recorrente: Secretária Municipal da Cultura de Belo Horizonte

Recorrida: Cinemas e Teatros de Minas Gerais S/A

Resumo: Apelação contra determinação de uso para atividade artístico-cultural dos Cines Pathé e Brasil, tombados. Alega-se que a lei de tombamento não obriga a determinadas funções no imóvel, o que só poderia acontecer se a partir da desapropriação.

\begin{tabular}{|l|c|}
\hline \multicolumn{1}{|c|}{ Recurso Extraordinário n. 41.279 Guanabara } & $09 / 09 / 65$ \\
\hline Embargante: Manoel Mendes Campos & \\
\hline Embargada: União Federal & $\begin{array}{l}\text { Resumo: Recurso contra construção de prédio próximo de Bem Tombado, no caso o } \\
\text { Outeiro da Glória. }\end{array}$ \\
\hline
\end{tabular}

\begin{tabular}{|l|c|}
\hline \multicolumn{1}{|c|}{ Mandado de Segurança n. 16.638 MG } & 20/03/67 \\
\hline Recorrentes: Augusto Lopes de Vasconcelos e sua mulher & \\
\hline Recorrida: Prefeitura Municipal de Sabará & $\begin{array}{l}\text { Resumo: Contestação do ato de tombamento da União em imóvel no município de } \\
\text { Sabará }\end{array}$ \\
\hline
\end{tabular}




\begin{tabular}{|l|c|}
\hline \multicolumn{1}{|c|}{ Representação n. 640 GO } & 14/04/66 \\
\hline Recorrente: Procurador Geral da República & \\
\hline Recorrida: Assembléia Legislativa de Goiás & \\
\hline $\begin{array}{l}\text { Resumo: Pleiteada inconstitucionalidade da Lei Estadual 4.337/64 que erigiu a } \\
\text { cidade de Goiás em "Cidade Monumento" por julgarem ferir a autonomia dos } \\
\text { municípios. }\end{array}$ \\
\hline
\end{tabular}

\begin{tabular}{|c|c|}
\hline Representação n. 756 SE & 22/04/70 \\
\hline \multicolumn{2}{|l|}{ Representante: Procurador-Geral da República } \\
\hline \multicolumn{2}{|c|}{ Representada: Assembléia Legislativa do Estado de Sergipe } \\
\hline $\begin{array}{l}\text { Resumo: Inconstitucionalidade da Constituição } \\
\text { outras coisas, estabelece ao Governador, com } \\
\text { Legislativa, a nomeação do Prefeitos da Capita } \\
\text { estâncias hidro-minerais, assim como aqueles } \\
\text { patrimônio histórico e artístico nacional. }\end{array}$ & $\begin{array}{l}\text { que, entre } \\
\text { Assembléia } \\
\text { onsiderados } \\
\text { s mediante }\end{array}$ \\
\hline
\end{tabular}

\begin{tabular}{|l|c|}
\hline \multicolumn{1}{|c|}{ Representação n. 1.336-7 } & 26/10/88 \\
\hline Representante: Procurador-Geral da República & \\
\hline Recorrida: Assembléia Legislativa do Estado do Rio Grande do Sul \\
\hline $\begin{array}{l}\text { Resumo: Inconstitucionalidade da Lei Estadual n. 8.133/85, que "Inscreve no } \\
\text { Patrimônio Cultural do Estado o Monumento do Centenário da Imigração Alemã, de } \\
\text { Novo Hamburgo". }\end{array}$ \\
\hline
\end{tabular}




\subsubsection{Tribunal Regional Federal}

\begin{tabular}{|l|c|}
\hline \multicolumn{1}{|c|}{ Apelação Criminal n. 94.01.02974-7 MG } & 26/06/95 \\
\hline Apelantes: Antonio Pontes da Fonseca e Leonildo P. da Fonseca & \\
\hline Apelada: Justiça Pública & $\begin{array}{l}\text { Resumo: Apelação contra condenação de responsáveis por destruição de sítio } \\
\text { arqueológico, patrimônio da União. Crime de Dano por destruição de sítio com } \\
\text { pinturas rupestres, localizado no município de Matozinhos - MG. Alegou-se que não } \\
\text { estava comprovada a materialidade do delito. }\end{array}$ \\
\hline
\end{tabular}

\begin{tabular}{|c|c|}
\hline Agravo de Instrumento n. 2004.01.00.002571-6 AM & 16/11/04 \\
\hline \multicolumn{2}{|c|}{ Recorrente: Superintendência de Habitação e Assuntos Fundiários - SUHAB } \\
\hline \multicolumn{2}{|l|}{ Recorrida: Ministério Público Federal } \\
\hline \multicolumn{2}{|c|}{$\begin{array}{l}\text { Resumo: Agravo contra decisão liminar que impôs aos réus, em ação civil pública, a } \\
\text { adoção de medidas urgentes para recuperação e prevenção de danos causados em } \\
\text { sítio arqueológico descoberto durante obras de construção de projeto habitacional. }\end{array}$} \\
\hline
\end{tabular}

Apelação Cível n. 9301137534 MG

$14 / 12 / 93$

Resumo: Competência para julgar a ação civil pública de responsabilidade por danos causados ao meio-ambiente. Deve ser proposta no foro do local do dano. Se for sede de vara federal, a competência é do juiz federal, sobretudo quando a lesão atinge Bem da União (Sítio Arqueológico). 


\subsubsection{Superior Tribunal de Justiça}

\begin{tabular}{|l|l|}
\hline \multicolumn{1}{|c|}{ Recurso Especial n. 115.599 RS } & 27/06/02 \\
\hline Recorrente: Ministério Público do Estado do Rio Grande do Sul & \\
\hline Recorrido: Clube dos Caçadores do Rio Grande & $\begin{array}{l}\text { Resumo: Recurso contra decisão do Juiz que condenou ao réu, pela destruição de } \\
\text { sítio arqueológico e dunas de areia. Na decisão, o Juiz determinou ao réu "abster-se } \\
\text { de destruir o meio ambiente e o patrimônio cultural, condenando-o ao pagamento de } \\
\text { indenização ao erário público". }\end{array}$ \\
\hline
\end{tabular}

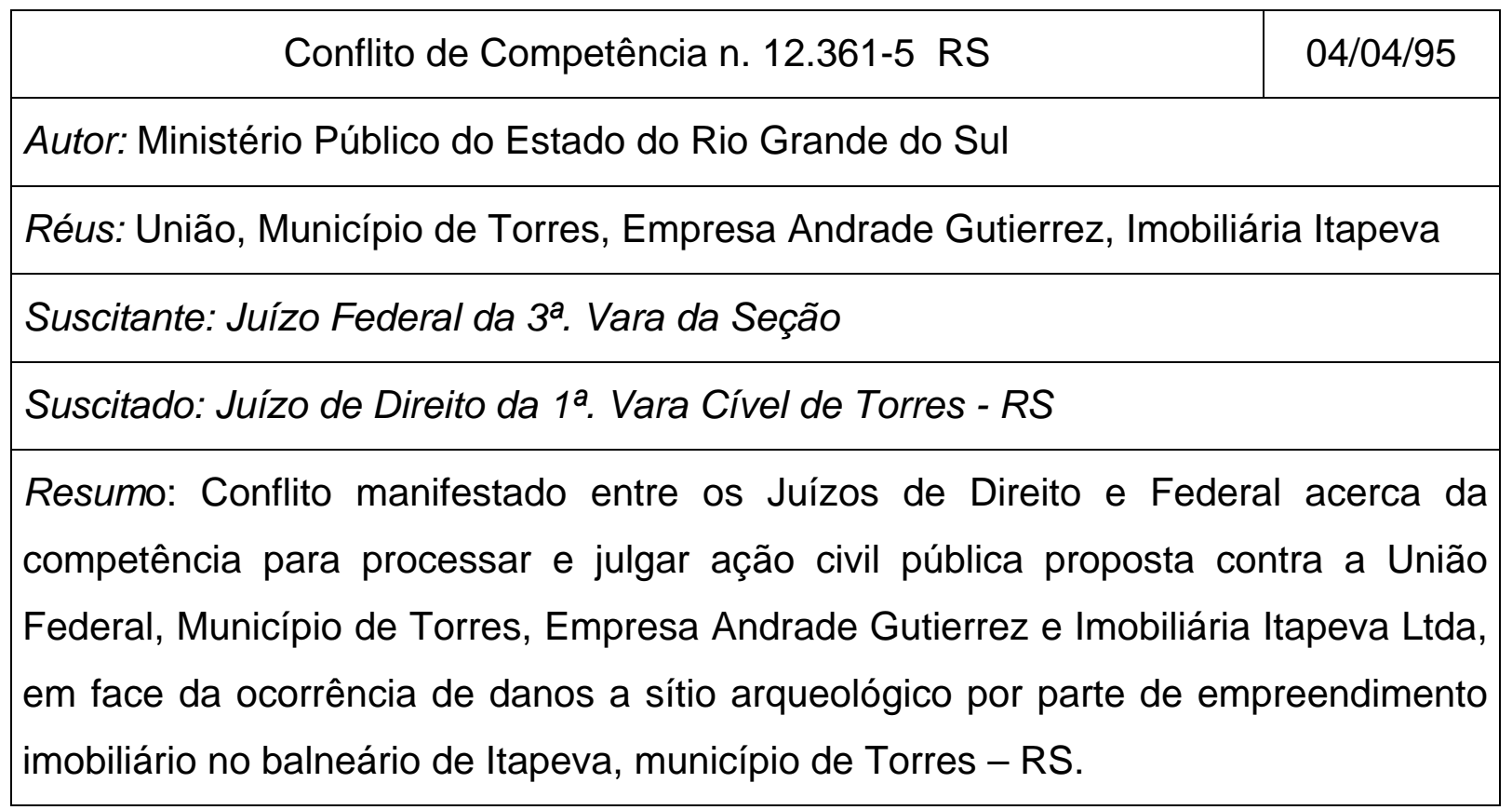

\begin{tabular}{|l|c|}
\hline \multicolumn{1}{|c|}{ Apelação Cível n. 55.415-5/0 } & $03 / 2002$ \\
\hline Apelante: Ministério Público do Estado de São Paulo & Apelados: Sociedade Cooperação dos Aposentados e Pensionistas da Sorocabana \\
- SCAPS e a Prefeitura Municipal de Sorocaba & $\begin{array}{l}\text { Resumo: Apelação contra pretensão do MP visando obtenção de indenização pela } \\
\text { demolição de prédios históricos de valor histórico e cultural. }\end{array}$ \\
\hline
\end{tabular}




\subsubsection{Tribunais de Justiça}

\begin{tabular}{|l|l|}
\hline \multicolumn{1}{|c|}{ Agravo n. 000.283.475-2/00 MG } & 13/02/03 \\
\hline Agravante: Albertina Chacur e outros & \\
\hline Agravado: Prefeito Municipal de Uberlância e outros & $\begin{array}{l}\text { Resumo: Os agravantes desejam assegurar o seu direito de realizarem a demolição } \\
\text { de construções existente em imóvel que se encontra em processo de tombamento } \\
\text { pelo Conselho Municipal. }\end{array}$ \\
\hline
\end{tabular}

\begin{tabular}{|l|c|}
\hline \multicolumn{1}{|c|}{ Apelação Cível n. 000.256.230-4/00 MG } & 07/11/02 \\
\hline Apelante: Jarbas de Souza e outra & Apelado: Município de Juiz de Fora \\
\hline $\begin{array}{l}\text { Resumo: Apelação contra sentença que julgou improcedente o pedido de nulidade } \\
\text { do tombamento de imóvel de sua propriedade, realizado pelo município. }\end{array}$ \\
\hline
\end{tabular}

\begin{tabular}{|c|c|}
\hline Embargos de Declaração n. 000.191.668-3/01 MG & 07/03/02 \\
\hline \multicolumn{2}{|l|}{ Embargante: Município de Lagoa Santa e outros } \\
\hline \multicolumn{2}{|l|}{ Embargado: Nestor Eduardo Araruna Santiago } \\
\hline $\begin{array}{l}\text { Resumo: Embargo interposto pelo Município de Lagoa Santa } \\
\text { TJ-MG, pela ausência de citação dos litisconsortes, especif } \\
\text { Minas Gerais e o Secretário de Estado do Planejame } \\
\text { necessidade em função da aprovação municipal do loteamen } \\
\text { o não disciplinamento observado pelo Estado. Lembra o Rel } \\
\text { que a Lei no } 6.766 \text {, de } 19 \text { de Dezembro de } 1979 \text {, que dispõe } \\
\text { do Solo Urbano, em seu art. } 13 \text {, com redação dada pela } \\
\text { dispõe que aos Estados caberá disciplinar a aprovação } \\
\text { loteamentos e desmembramentos na seguinte condição: } \S ~ “ \\
\text { em áreas de interesse especial, tais como as de proteção } \\
\text { patrimônio cultural, histórico, paisagístico e arqueológico, } \\
\text { legislação estadual ou federal”. }\end{array}$ & $\begin{array}{l}\text { acórdão do } \\
\text { Estado de } \\
\text { ndem essa } \\
\text { cial Visão e } \\
\text { ra Machado } \\
\text { arcelamento } \\
85,29.1 .99 \text {, } \\
\text { unicípios de } \\
\text { localizados } \\
\text { cciais ou ao } \\
\text { efinidas por }\end{array}$ \\
\hline
\end{tabular}




\begin{tabular}{|l|c|}
\hline \multicolumn{1}{|c|}{ Apelação Cível n. 000.198.640-5/00 } & 21/12/00 \\
\hline Apelante: JD. V. Faz. Comarca de Juiz de Fora, Município de Juiz de Fora e outro \\
\hline Apelado: Sindicato dos Empregados do Comércio de Juiz de Fora \\
\hline $\begin{array}{l}\text { Resumo: Apelação contra decisão do TJ que reconheceu a incompetência do } \\
\text { município para legislar sobre tombamento. }\end{array}$ \\
\hline
\end{tabular}

\begin{tabular}{|l|c|}
\hline \multicolumn{1}{|c|}{ Apelação Cível n. 000.192.352-3/00 MG } & $14 / 12 / 00$ \\
\hline $\begin{array}{l}\text { Apelante: JD. V. Faz. Mun. Comarca de Belo Horizonte, Município de Belo Horizonte } \\
\text { e outros }\end{array}$ \\
\hline Apeladas: Maria Augusta Gomes e outras \\
$\begin{array}{l}\text { Resumo: Apelação contra decisão do TJ que acolheu a segurança postulada pelas } \\
\text { apeladas, de que a defesa das mesmas ficou prejudicada no processo de } \\
\text { tombamento de seu imóvel, considerando que as mesmas não foram informadas } \\
\text { dos motivos que levaram ao tombamento. }\end{array}$ \\
\hline
\end{tabular}

\begin{tabular}{|l|c|}
\hline \multicolumn{1}{|c|}{ Apelação Cível n. 000.198.743-7/00 MG } & 21/11/00 \\
\hline Apelante: Vera Rabelo Leão & \multicolumn{1}{|c|}{ Apelado: Município de Belo Horizonte } \\
\hline $\begin{array}{l}\text { Resumo: Apelação contra decisão que julgou improcedente a ação anulatória da } \\
\text { que o mesmo não possui valor histórico ou cultural. }\end{array}$ \\
\hline
\end{tabular}

\begin{tabular}{|l|c|}
\hline \multicolumn{1}{|c|}{ Apelação Cível n. 000.141.703-9/00 } & 21/11/00 \\
\hline Apelante: JD. 2ª. V. Faz. Mun. Comarca de Belo Horizonte, Município de Belo Horizonte \\
\hline Apelada: Mannesmann Mineração Ltda. \\
\hline $\begin{array}{l}\text { Resumo: Apelação contra decisão favorável a apelada que teria isento seu imóvel } \\
\text { situado na Serra do Curral, área esta tombada pelo IPHAN. }\end{array}$ \\
\hline
\end{tabular}




\section{BIBLIOGRAFIA}




\section{BIBLIOGRAFIA}

ALBERNAZ, Larissa Crescini. Da competência em Ação Civil Pública nos casos de dano ambiental a bens de domínio da União. São Paulo: Ministério Público de São Paulo. Disponível na Rede Mundial de Computadores no endereço: http://www.mp.sp.gov.br/caouma/caouma.htm

AB'SÁBER, Aziz Nacib, MÜLLER-PLATEBERG, Clarita, org. Previsão de Impactos: O Estudo de Impacto Ambiental no Leste, Oeste e Sul. Experiências no Brasil, na Rússia e na Alemanha. São Paulo: Editora da Universidade de São Paulo, 1994.

ABREU, Sílvio Fróis. Sambaquis de Imbituba e Laguna. Separata da Revista da Sociedade Brasileira de Geografia. Rio de Janeiro, 1928.

ALARCÓN, Andrés J. La idea de historia en arqueología. In: Mahecha Ana María Groot de. Reflexiones sobre la mitología concerniente al estudio del espacio y del tiempo. Bogotá: Universidad Nacional de Colombia, Marzo 2002-Agosto 2003.

ALMEIDA, Adriana M.; VASCONCELOS, Camilo de M. O trabalho interdisciplinar nos Museus. Ciências em Museus, n. 04, 129 - 133.

ARAUJO, Luiz A. D., NUNES JR, Vidal S. Curso de Direito Constitucional. São Paulo: Saraiva, 2002.

BANDEIRA, Dione da Rocha. Gestão Arqueológica nos municípios: a experiência de Joinville/SC. Texto apresentado no XI Congresso da Sociedade de Arqueologia Brasileira, Rio de Janeiro, 2001.

BARRETO, Cristiana. Arqueologia Brasileira: uma perspectiva histórica e comparada. Revista do Museu de Arqueologia e Etnologia, São Paulo, Suplemento 3, São Paulo: MAE/USP, 1999, p. 201 - 212.

BARROIS, Nadine; Demarez, Léonce; Henton, Alain. Lês Sites de Reconstituitions. Archéologie, n. 293, 1993.

BASTOS, Celso R. Comentários à Constituição do Brasil, $2^{\circ}$ vol. Arts. $5^{\circ}$ ao 17 , São Paulo: Saraiva, 1989. 
BASTOS, Rossano Lopes. Condutas éticas e responsabilidades introduzidas pela Arqueologia de Contrato. Florianópolis, 2002. Texto não publicado.

BASTOS, Rossano Lopes. Patrimônio Arqueológico, Preservação e Representações Sociais: Uma proposta para o País através da análise da situação do Litoral Sul de Santa Catarina. São Paulo, 2002, Tese de Doutoramento apresentada no : MAE/USP.

BAYARDO, Rubens. Antropologia, Identidad y Políticas Culturales. Ciudad Virtual de Antropología e Arqueología: Naya, 2001.

BELLONI, Isaura; MAGALHÃES, Heitor de; SOUSA, Luzia Costa. Metodologia de avaliação de políticas públicas. São Paulo: Ed. Cortez, 2000.

BENJAMIN, Walter. Documentos de Cultura. Documentos da Barbárie (escritos escolhidos). São Paulo: Ed. Cutrix/EDUSP, 1986.

BICA, Briane E. P. Centro Histórico: um conceito limitativo. Texto apresentado no Seminário sobre Centros Históricos realizado em Itaipava. Petrópolis: Comitê Brasileiro do ICOMOS, 1987.

BLASI, Oldemar, GAISSLER, Miguel L., PONTES FILHO, Almir. Primeiras notícias sobre os serviços de levantamento e cadastramento de sítios arqueológicos em Guaraqueçaba - Paraná. In: Reunião Científica da Sociedade de Arqueologia Brasileira, 4, 1998, São Paulo. Anais. Incluído em: Dédalo. Publicações Avulsas. São Paulo, nº 01, pp. 108 - 132.

BOBBIO, Norberto. Política Cultural. Torino: Einaurdi, 1977.

BORGES, Marco Antônio. O tombamento como instrumento jurídico para a proteção do patrimônio cultural. Revista de Direito Ambiental, v.22, abr. - jun., 2001, p. 259-263.

BRUNO, Maria C. O. A importância dos processos museológicos para a preservação do patrimônio. Revista do Museu de Arqueologia e Etnologia, Suplemento 3, 1999, p. $333-337$.

BRUNO, Maria C. O. A pesquisa em Museologia: o Programa Técnico-Científico do Museu de Arqueologia e Etnologia da Universidade de São Paulo. Ciências em Museus, n. 03, 1991, p. 09 - 26. 
BRUNO, Maria C. O. Formas de Humanidade: Concepção e desafios da musealização. Cadernos de Sociomuseologia, n. 09, 1996, p. 65 - 88.

BRUNO, Maria C. O. Museus de Arqueologia no Brasil: uma história de coadjuvantes. Cadernos de Sociomuseologia, n. 17. Universidade Lusófona de Humanidades e Tecnologias, 1999, p. 71 - 102.

BRUNO, Maria C. O. Museus de Arqueologia: uma história de conquistadores, abandono e mudanças. Revista do Museu de Arqueologia e Etnologia. São Paulo, n. 6, 1996, p. $293-313$.

BRUNO, Maria C. O. Os necessários alicerces para o desenvolvimento dos processos museais: o Programa de Estudos Museológicos. Ciências em Museus, n. 04, 1992, p. 45 - 49.

BRUNO, Maria C. O.; ARAUJO, Marcelo Mattos. (orgs). A memória do pensamento museológico contemporâneo. Comitê Brasileiro do ICON, 1995.

BRUNO, Maria C. O.; NEVES, Walter Alves. Ossos para ofício: proposta, execução e avaliação de uma exposição temporária. Ciências em Museus, 1989, p. 39 58.

BRUNO, Maria Cristina Oliveira, et al. Um Olhar museológico para a arqueologia: a exposição "Pré-História Regional de Joinville". Revista do Museu de Arqueologia e Etnologia. São Paulo, nº1, pp. 113 - 129, 1991.

BUGALHO, Nelson R. Estudo prévio de Impacto Ambiental: aspectos relevantes. São Paulo: Ministério Público de São Paulo. Disponível na Rede Mundial de Computadores no endereço:

http://www.mp.sp.gov.br/caouma/caouma.htm

CALI, Plácido. Paisagens da Juréia: estudo interdisciplinar sobre o povoamento do litoral sul paulista In: DIEGUES, Antonio C. Sant' Anna. Enciclopédia Caiçara, Vol. I - O Olhar do Pesquisador. São Paulo: Ed. Hucitec/NUPAUB - USP, 2004d, pp. $71-90$.

Projeto Arqueológico resgata 1682 peças do sítio no Veloso. Jornal da Ilha. Ilhabela, set. 2004c. p. 05. 
Fortificações, canhões e o sistema defensivo de Ilhabela antiga.

Cartilha da Cultura. Ilhabela: Secretaria Municipal da Cultura, mai. 2004b, $n$. 07.

O Plano Diretor e a Preservação do Patrimônio Cultural. Jornal da Ilha. Ilhabela, fev. 2004a. p. 07.

O Patrimônio Arqueológico de Ilhabela. Cartilha da Cultura. Ilhabela: Secretaria Municipal da Cultura, nov. 2003d, n. 05.

Sítio Arqueológico Engenho Pacuíba I. São José dos Campos: Asseart, 2003c.

Projeto Arqueológico realiza Exposição. Jornal da Ilha. Ilhabela, mar. 2003b. n. 66, p. 10.

Projeto Arqueológico cria Site na Internet. Jornal da Ilha. Ilhabela, fev. 2003a. n. 65, p. 08.

História da Cultura Brasileira e Fontes Arqueológicas. Revista Fronteiras, n. 11, Mato Grosso do Sul: Ed. UFMS, $2002 \mathrm{~g}$.

Mais 12 sítios arqueológicos são encontrados em llhabela. Jornal da Ilha. Ilhabela, out. 2002f. n. 63, p. 13.

- Pederneiras, cachimbos e moedas: conhecendo o sítio Engenho Pacuíba. Jornal da Ilha. Ilhabela, out. 2002e. n. 62, p. 13.

- Novo sítio arqueológico descoberto em Ilhabela. Jornal da Ilha. Ilhabela, ago. 2002d. n. 61, p. 03.

. Projeto Arqueológico conclui estudo de 12.000 peças arqueológicas do sítio Engenho Pacuíba. Jornal da Ilha. Ilhabela, jul. 2002c. n. 60, p. 07.

. Cacos, louças e outras Histórias. Jornal da Ilha. Ilhabela, maio. 2002b. n. 58, p. 09.

Salvamento arqueológico do sítio Engenho Pacuíba I. Jornal da Ilha. Ilhabela, abr. 2002a. n. 57, p. 02.

. Gestão do Patrimônio Arqueológico no município de Ilhabela/SP.

Anais do I Encontro Sul Brasileiro de Educação Patrimonial. Tubarão: UNISUL, 2001n. 
. Preservação do patrimônio arqueológico no plano municipal. Anais do I Encontro Sul Brasileiro de Educação Patrimonial. Tubarão: UNISUL, $2001 \mathrm{~m}$.

- Projeto Arqueológico de Ilhabela. Caderno de Resumos do XI Congresso da Sociedade de Arqueologia Brasileira. Rio de Janeiro: SAB, 2001k, p. 138.

Arqueologia, História e Paisagem: o caso da Juréia. Caderno de

Resumos do XI Congresso da Sociedade de Arqueologia Brasileira. Rio de Janeiro: SAB, 2001I, p. 104 e 105.

- Ilhabela no XI Congresso da Sociedade de Arqueologia Brasileira. Jornal da IIha. Ilhabela, out. 2001j. n. 53.

. Fortificações, Canhões e o Sistema Defensivo de Ilhabela antiga. Jornal da Ilha. Ilhabela, set. 2001i. n. 52, p. 09.

. Conservação e preservação dos sítios arqueológicos de Ilhabela. Jornal da Ilha. Ilhabela, ago. 2001h. n. 51, p. 08.

. Turismo cultural e patrimônio arqueológico. Jornal da Ilha. Ilhabela, jul. 2001g. n. 50, p. 05.

A proteção do Patrimônio Cultural e o papel dos municípios. Jornal da Ilha. Ilhabela, jun. 2001f. n. 49.

- Engenhos do demônio, engenhosidade humana. Jornal da Ilha. Ilhabela, maio. 2001e. n. 48.

. Engenhos, Fazendas e Fortificações: ruínas da História de Ilhabela. Jornal da Ilha. Ilhabela, abr. 2001d. n. 47.

Abrigos pré-históricos de Ilhabela. Jornal da Ilha, Ilhabela, mar. 2001c. n. 46.

. Projeto Arqueológico de Ilhabela. Jornal da Ilha, Ilhabela, fev. 2001b. n. 45.

. Os primeiros habitantes de Ilhabela. Parte II: agricultores e ceramistas. Jornal da Ilha, Ilhabela, jan. 2001a. n. 44. 
Os primeiros habitantes de Ilhabela. Parte I: pescadores e coletores. Jornal da Ilha, Ilhabela, dez. 2000b. n. 43.

Ilhabela resgata patrimônio arqueológico. Jornal da Ilha. Ilhabela, nov. 2000a. n. 42.

Sítio Arqueológico Rio Comprido I e seu contexto no Vale do Paraíba. Jacareí: Mirante do Vale, 1999.

- Pariquera-Açú e o Patrimônio Cultural do Vale do Ribeira. Caderno Especial do Curso Básico de Monitores Ambientais do Vale do Ribeira, V. 02, Pariquera-Açú: Instituto Florestal/SMA, dezembro de 1998c.

. Iguape: Patrimônio Cultural. Caderno Especial do Curso Básico de

Monitores Ambientais do Vale do Ribeira, V. 01, Iguape: Instituto Florestal/SMA, novembro de 1998b.

et alli. Memória e Preservação. Patrimônio Cultural de São José dos Campos. São José dos Campos: Fundação Cultural Cassiano Ricardo, 1998a.

. Arqueologia em São José dos Campos. In: Revista Esfera n. 46. São José dos Campos: Fundação Cultural Cassiano Ricardo, 1997b.

. Juréia: patrimônio cultural de Iguape. In: Tribuna de Iguape n. 13, Iguape: Editora Princesa do Litoral Ltda-ME., 1997a.

Arqueologia da Paisagem: o caso da Juréia. In: Caderno Paisagem Paisagens n. 02, Bauru: UNESP, 1996.

Reserva Indígena de Peruíbe: um estudo sócio-cultural dos guaranis. In: EKMAN, Maya. Peruíbe, História das suas Origens, Contos e Lendas. Peruíbe: Editora Peruíbe, 1991.

. A história da aldeia guarani do Bananal. In: HERRERA, Oswaldo (org.). Peruíbe, terra da esperança. Peruíbe: Editora Peruíbe, 1991.

CARNEIRO, Ruy de Jesus Marçal. Organização da cidade. Planejamento municipal, plano diretor, urbanificação. São Paulo: Max Limonad, 1998. 
CASTILHO, Ela Wiecko Volkmer de. A preservação do meio ambiente e da cultura na legislação brasileira. Revista da Procuradoria Geral da República, v. 4, s.d., p.98-103.

CASTRO, José Nilo de. Direito municipal positivo. Belo Horizonte: Editora Del Rey, 1991.

CAVALCANTI FILHO, Cary C, et al. A Fundação Mário Peixoto e a preservação do patrimônio cultural de Mangaratiba - Rio de Janeiro. In: Reunião Científica da Sociedade de Arqueologia Brasileira, 4, 1987, São Paulo. Anais. Incluído em: Dédalo. Publicações Avulsas. São Paulo, n 01, pp. 103 - 107, 1989.

CAVALCANTI, Temístocles Brandão. Patrimônio histórico. Tombamento. Notificação. Registro. Revista de Direito Administrativo, v.119, jan. - mar., 1975, p.428-434.

CENTRO DE ARQUEOLOGIA DE ALMADA, Museus com Coleções de Arqueologia. Al Madan, $11^{\mathrm{a}}$ Série, n. 02, julho de 1993.

CENTRO DE ESTUDOS CULTURA E CIDADANIA. Uma cidade numa ilha: relatório sobre os problemas sócio-ambientais da Ilha de Santa Catarina. Florianópolis: Insular, 1997.

CHAUÍ, Marilena. Brasil. Mito fundador e sociedade autoritária. São Paulo: Ed. Fundação Perseu Abramo, 2000. . Cultura e Democracia. O discurso competente e outras falas. São Paulo: Ed. Moderna, 1980.

CHILDE, Alberto. Arqueologia clássica e americanismo. Arquivos do Museu Nacional. Rio de Janeiro, 1916, vol. XIX.

COELHO, Luiz Fernando. A competência concorrente em Direito Ambiental. Revista de Informação legislativa. Brasília, ano 29, nº 114, abr. - jun., 1992.

COHN, Gabriel. Concepção oficial de cultura e processo cultural. Revista do Patrimônio Histórico e Artístico Nacional, n. 22. Rio de Janeiro: Iphan, 1987, p. $07-10$. 
CONSENS, Mario. Patrimônio Nacional como autarquia: el ejemplo Del Uruguay. Anais do $1^{\circ}$ Congresso Virtual de Antropología y Arqueologia. Ciberespacio, Outubro de 1998.

COSTA, Adroaldo Mesquita da. Patrimônio histórico e artístico nacional. Tombamento. Desapropriação. Revista Forense, v. 213, jan. - mar., 1966, p.57-60.

COSTA, J. Angyone. Manifestations of art in Brasilian Archaeology. The studio. Londres, 1943.

Arqueologia geral. Ed. Nacional, São Paulo, 1936.

Migrações e cultura indígena. São Paulo: Ed. Nacional, 1938. (col. Brasiliana)

COTA, Odil José; ABREU, Alexandre Herculano. Guia Prático para Identificação de Infrações Penais Ambientais. Florianópolis, Ministério Público do Estado de Santa Catarina, 2004.

CRETELLA JÚNIOR, José. Dos bens públicos na Constituição de 1988. Revista dos Tribunais, v. 653, mar.,1990, p.16-48.

CUSTÓDIO, Helita Barreira. Normas de proteção ao patrimônio cultural brasileiro em face da constituição federal e das normas ambientais. Revista de Direito Ambiental, v. 6, abr. - jun., 1997, p. 17-39.

CUSTÓDIO, Helita Barreira. Proteção do patrimônio histórico, cultural e natural: seu evidente interesse público. Revista de Direito Civil, Imobiliário, Agrário e Empresarial, v. 49, jul. - set., 1989, p.166-174.

DE BLASIS, Paulo A. D., PIEDADE, Silvia C. M. As pesquisas do Instituto de PréHistória e seu acervo: balanço preliminar e bibliografia comentada. Revista do Museu de Arqueologia e Etnologia. São Paulo, nº 01, pp. 165 - 187, 1991.

DELPORTE, Henri. Le Rôle des Musées dans la connaissance de la Préhistoire. La Préhistoire en France. Actes du $114^{\circ}$ Congrès National des Sociétés Savantes. Paris: Editions du C.T.H.S., 1992.

DIPP, Gílson. O meio ambiente na visão do STJ. In: Cidadania e Justiça. O papel do Judiciário na proteção ambiental. Rio de Janeiro: AMB, ano 4, nº 9, 2000. 
DUCLOS, Jean Claude. Le musee lieu de dialogue social? Exposer. Vendredi, 1998.

FALKNER, Neil. Archaeology from below. Public Archaeology, vol. 1, n. 01, London: James \& James, 2000, p. 21 - 33.

FERDIÈRE, Alain. La Fouille pour quoi faire? In: SCHNAPP, Alain, org. Archéológie aujourd'hui. Paris: Hachette, 1980.

FERREIRA, João Henrique. A Criminalização Específica da Improbidade Administrativa. São Paulo: Ministério Público de São Paulo. Disponível na Rede Mundial de Computadores no endereço: http://www.mp.sp.gov.br/caouma . A responsabilidade penal das pessoas jurídicas e sua aplicabilidade aos crimes ambientais. São Paulo: Ministério Público de São Paulo. Disponível na Rede Mundial de Computadores no endereço: http://www.mp.sp.gov.br/caouma

FERREIRA, Luís Pinto. A autonomia política dos municípios. Revista de Direito Público, v. 7, jan. - mar., 1969, p.157-167.

FONSECA, Maria Cecília Londres. O patrimônio em processo: trajetória da política federal de preservação no Brasil. Rio de Janeiro: UFRJ/Iphan, 1997.

FRANCO, Luiz Fernando P. N. Centro Histórico de Laguna. Cadernos de Documentos nº2. Rio de Janeiro: Ministério da Cultura/Iphan, 1985.

FREITAS, José Carlos de. Dos interesses metaindividuais urbanísticos. São Paulo: Ministério Público de São Paulo. Disponível na Rede Mundial de Computadores no endereço: http://www.mp.sp.gov.br/caouma/caouma.htm

FREITAS, José Carlos de. O Estatuto da Cidade e o equilíbrio no espaço urbano. São Paulo: Ministério Público de São Paulo. Disponível na Rede Mundial de Computadores no endereço: http://www.mp.sp.gov.br/caouma/caouma.htm

FREITAS, Vladimir Passos de, FREITAS, Gilmar Passos de. Crimes contra a natureza. 6. ed. São Paulo: Revistas dos Tribunais, 2000, p. 32.

FUNARI, Pedro Paulo A. A Hermenêutica das ciências humanas: a história e a teoria e práxis arqueológicas. Revista da Sociedade Brasileira de Pesquisa Histórica. Curitiba, nº 10, 1995. 
A importância da teoria arqueológica internacional para a

Arqueologia Sul-Americana: o caso brasileiro. Revista do Museu de Arqueologia e Etnologia, São Paulo, Suplemento 3, São Paulo: MAE/USP, 1999, p. $213-220$.

. Como se tornar arqueólogo no Brasil. Revista USP, n. 44, São Paulo: Edusp, 1999-2000, p. $74-85$.

- Reflexões sobre a mais recente teoria arqueológica.

Revista de Pré-História. São Paulo, v. 07, 1989.

. Teoria Arqueológica na América do Sul. Campinas:

IFCH/UNICAMP, 1998.

. Western influences in the archaeological thought in Brazil,

Teoría Arqueológica en América del Sur, Gustavo Politis y Roberto Peretti (eds), Olavarría, Incuapa/Unicen, 2004, 235-244,

; PINSKY, Jaime. Turismo e Patrimônio Cultural. São

Paulo: Ed. Contexto, 2001.

GAMA, Guilherme Calmon Nogueira da. A autonomia do município brasileiro. Revista do Instituto de Pesquisas e Estudos. Divisão Jurídica, v. 21, abr. jul., 1998, p.141-172.

GIKOVATE, Moysés. Os sambaquis. Revista Nacional de Educação. Rio de Janeiro, 1933.

GOELDI, Emílio A. Escavações arqueológicas em 1895. Memórias do Museu Goeldi. 1905.

GOVERNO DO ESTADO DE SÃO PAULO. Pesquisando São Paulo: 110 anos de criação da Comissão Geográfica e Geológica. São Paulo; Instituto Geológico/SMA; Museu Paulista/USP; Instituto Florestal/SMA, 1996.

GUARNIERI, Waldisa Russio C. Conceito de Cultura e sua inter-relação como o patrimônio cultural e a preservação. Revista do IBPC n. 03, 1990, p. 07 - 12.

GUTIÉRREZ, Ramón. A preservação do Patrimônio Arquitetônico como agente dinamizador da consciência cultural americana. Texto apresentado no 
Seminário sobre Centros Históricos realizado em Itaipava. Petrópolis: Comitê Brasileiro do ICOMOS, 1987.

HOBSBAWM, Eric. Nações e nacionalismo desde 1780: Programa, mito e realidade. Rio de Janeiro: Ed. Paz e Terra, 1990.

HODDER, Ian. Interpretación en Arqueologia. Corrientes actuales. Barcelona: Editorial Crítica, 1988.

. Reading the Past. Current approaches to Archaeology. Cambridge, Cambridge University Press, 1986.

HOLTORF, Cornelius. Engaging with múltiple past. Public Archaeology, vol. 3, London: James \& James, 2000, p. $214-215$.

HURLEY, Henrique Jorge. Pré-história americana. Revista do Instituto Histórico e Geográfico do Pará. Belém, 1931, vol. IV

IGLESIAS, Francisco. Historiadores do Brasil: capítulos de historiografia brasileira. Rio de Janeiro: Nova Fronteira, 2000.

IHERING, H. von. A civilização pré-histórica do Brasil meridional. Revista do Museu Paulista. São Paulo, 1895, vol. I, p. 34 - 159.

. Arqueologia comparativa do Brasil. Revista do Museu Paulista.

São Paulo, 1904, vol. VI

. Fósseis de São José do Rio Preto. Revista do Museu Paulista.

São Paulo, 1911, vol. VIII.

IMBELLONI, José. Fuéguidos y Lágidos Posicion actual de la raza paleo-americana o de Lagoa Santa. Anales del Museo Argentino de Ciências Naturales. Buenos Aires, 1937, tomo XXXIX, p. 79 - 104.

INSTITUTO DE PESQUISA E PLANJAMENTO URBANO DE JOINVILLE. Joinville

- Cidade em Dados. Joinville: Prefeitura Municipal, 2001.

INSTITUTO DE PLANJAMENTO URBANO DE FLORIANÓPOLIS. Valorização do Casario Histórico de Florianópolis: Manual de recuperação. Florianópolis: IPUF, 1993. 
INSTITUTO DO PATRIMÔNIO HISTÓRICO E ARTÍSTICO NACIONAL. Boletim Informativo e Técnico do Laboratório de Estudos e Pesquisas. Laguna, jan-fev, 1997.

INSTITUTO DO PATRIMÔNIO HISTÓRICO E ARTÍSTICO NACIONAL. Cartas Patrimoniais. Brasília, 1995.

INSTITUTO DO PATRIMÔNIO HISTÓRICO E ARTÍSTICO NACIONAL. Oficina de interpretação e sinalização de sítio arqueológico. Serranópolis, 1997.

INSTITUTO DO PATRIMÔNIO HISTÓRICO E ARTÍSTICO NACIONAL. Sítios Missioneiros. Porto Alegre: IPHAN/12 ${ }^{\mathrm{a}}$ SR, 1998.

INSTITUTO JOINVILLE 150 ANOS. Joinville 150 anos de História. Joinville, 2001.

ITAQUI, José. Educação Patrimonial: a experiência da Quarta colônia. Santa Maria: Pallotti, 1998.

JOINVILLE. PREFEITURA MUNICIPAL. A técnica enxaimel na colônia Dona Francisca. Núcleo de Patrimônio Histórico/ Coordenadoria de Patrimônio Histórico - FCJ, 2000.

JULIANI, Lúcia de J.C. O. Proposta para um Plano de Gestão Arqueológica do Município de São Paulo. Texto apresentado no XI Congresso da Sociedade de Arqueologia Brasileira. Rio de Janeiro, 2001.

KERN, Arno A. A arqueologia histórica, a história e os trinta povos das missões. Clio - Série Arqueologia. Recife, nº 25, 1989.

KONDER, Leandro. O Estado e os problemas da política cultural no Brasil de hoje. Revista do Patrimônio Histórico e Artístico Nacional, n. 22. Rio de Janeiro: Iphan, 1987, p. $11-17$.

KOVÁCS, Anamaria. A História de Blumenau em quadrinhos. Blumenau: Maju, 1999.

LACERDA, Belizário Antônio de. O direito de preferência como protetor do município na preservação do patrimônio histórico e artístico nacional. Revista Forense, v.284, out. - dez., 1983, p.47-55. 
LEIVA, Omar Fernández. Desarrollo Del pensamiento arqueológico en Cuba. In: POLITIS, Gustavo (ed). Arqueología en América Latina Hoy. Colômbia, 1992.

LEROI-GOURHAN, André. Fouilles de Pincevent. La section 36. Gallia Prehistoire. Paris: CNRS, 1972. VII ${ }^{\mathrm{e}}$ Supplément.

LÖEFGREN, Alberto. Os sambaquis de São Paulo. Comissão Geográfica e Geológica do Estado de São Paulo, São Paulo, 1893, bol. nº 09.

LOPES, Raimundo. Pontas de sílex lascado no Brasil. Separata do Boletim do Museu Nacional. Rio de Janeiro, 1927.

LUMBRERAS, Luis G. La Arqueologia como ciencia social. Lima: Ed. Inca, 1981.

MACEDO, Dimas. Proteção jurídica dos sítios arqueológicos. Revista Forense, v.317, 1992, p.207-208.

MACEDO, Dimas. Proteção jurídica dos sítios arqueológicos. Revista Forense, v.317, 1992, p.207-208.

MACHADO, Paulo Affonso Leme. Tombamento. Instrumento jurídico de proteção do patrimônio natural e cultural. Revista dos Tribunais, v. 563, set., 1982, p.1541.

MACKENZIE, R., STONE, P. Introduction: the concept of the excluded past. In: MACKENZIE, R., STONE, P. (eds.) The excluded Past. Londres: Unwin, 1990, pp. $01-14$.

MARCHESAN, Ana Maria Moreira. A proteção constitucional ao Patrimônio Cultural. Revista de Direito Ambiental, v. 20, out. - dez., 2000, p.111-120.

Alguns aspectos sobre a Lei dos Crimes Ambientais. Porto Alegre: Ministério Público do Rio Grande do Sul. Disponível na Rede Mundial de Computadores no endereço:

MARTINS, Celso. Farol de Santa marta. A Esquina do Atlântico. Florianópolis: Ed. Garapuru, 1997.

MARTINS, Maria Helena Pires. Políticas Culturais de conservação do patrimônio: o caso do mobiliário. São Paulo: Departamento de Biblioteconomia e Documentação - ECA, 1997, Tese de Livre-Docência. 
MCMANAMON, Francis P. Archaeological messages and messengers. Public Archaeology, vol. 1, n. 01, London: James \& James, 2000, p. $05-20$.

MEIRELLES, Hely Lopes. Direito Administrativo Brasileiro, 18ํe., São Paulo: Malheiros, 1990.

MEIRELLES, Hely Lopes. Patrimônio histórico. Tombamento. Estudos de Direito Público, v. 4/2 - v.5/1, jul./1985 - jun./1986, p.71-77.

MELLO, Amaitê lara Giriboni de. O Ministério Público e a Defesa do Patrimônio Cultural Imaterial. São Paulo: Ministério Público de São Paulo. Disponível na Rede Mundial de Computadores no endereço: http://www.mp.sp.gov.br/caouma

MENDES, Correia, A. A. Gravuras rupestres no Brasil. Porto, 1932.

MENESES, Ulpiano B. De. O Discurso Museológico: um desafio para os museus. Ciências em Museus, n. 04, 1992, p. 103 - 127.

MENSCH, Peter van. O objeto de estudo da museologia. Rio de Janeiro: UNIRIO/UGF, 1994.

MICELI, Sérgio (org). História das Ciências Sociais no Brasil, vol.1. São Paulo:

Ed. Sumaré, 2001.

MICELI, Sérgio; GOUVEIA, Maria Alice. Política cultural comparada. Rio de Janeiro: Funarte/Finep, 1985.

MILARE, Edis. Ação civil pública ambiental. Patrimônio cultural. JUSTITIA, v.143, jul. - set., 1988, p.113-121.

MINISTÉRIO DA CULTURA. A Invenção do Patrimônio: continuidade e ruptura na constituição de uma política oficial de preservação no Brasil. Rio de Janeiro: IPHAN/Departamento de Promoção, 1995.

MINISTÉRIO DA CULTURA. Planejamento municipal e preservação do Patrimônio Cultural. Brasília: SPHAN, 1982.

MIRANDA, Marcos Paulo de Souza. Tutela Penal do Patrimônio Arqueológico Brasileiro. Belo Horizonte: Procuradoria Geral de Justiça do Estado de Minas Gerais - CAO-MA. Disponível na Rede Mundial de Computadores no endereço: http://www.mp.mg.gov.br/caoma 
MOLINARI, Roberto. Orientaciones para la gestión y supervivencia de los recursos culturales: Proyecto de Reglamento para la Preservación del Patrimonio Cultural en Areas Protegidas de la APN. Anais do $1^{\circ}$ Congresso Virtual de Antropología y Arqueologia. Ciberespacio, Outubro de 1998.

MONTEIRO, Manoel Sérgio da Rocha. Defesa do Patrimônio Cultural - reflexões sobre a atuação do Ministério Público. São Paulo: Ministério Público de São Paulo. Disponível na Rede Mundial de Computadores no endereço: http://www.mp.sp.gov.br/caouma/caouma.htm

MONTEIRO, Manoel Sérgio da Rocha. Defesa do Patrimônio Cultural - reflexões sobre a atuação do Ministério Público. São Paulo: Ministério Público de São Paulo. Disponível na Rede Mundial de Computadores no endereço: http://www.mp.sp.gov.br/caouma/caouma.htm

MORAES, Luís Carlos S. de. Curso de Direito Ambiental. São Paulo: Atlas, 2002.

MORAIS, José Luiz de. Arqueologia da Bacia do Paranapanema: contexto e metodologia. Simpósio Internacional sobre teoria e método em arqueologia. Caderno de Resumos. São Paulo: MAE/USP, 1995.

MORLEY, Edna J. Como preservar os sítios arqueológicos. In: TENÓRIO, Maria C. Pré-História da Terra Brasilis. Rio de Janeiro: Editora UFRJ, 1999.

MUKAI, Toshio. O Estatuto da Cidade: anotações à lei $n^{\circ}$ 10.257, de 10 de julho de 2001. São Paulo: Saraiva, 2001.

MUSEU DE ARQUEOLOGIA E ETNOLOGIA. Relatório de Atividades 1996. São Paulo: MAE/USP, 1997.

MUSEU DE ARQUEOLOGIA E ETNOLOGIA. Relatório de Atividades 1997. São Paulo: MAE/USP, 1998.

MUSEU DE ARQUEOLOGIA E ETNOLOGIA. Relatório de Atividades 1998. São Paulo: MAE/USP, 1999.

MUSEU DE ARQUEOLOGIA E ETNOLOGIA. Relatório de Atividades 1999. São Paulo: MAE/USP, 2000.

MUSEU DE ARQUEOLOGIA E ETNOLOGIA. Relatório de Atividades 2000. São Paulo: MAE/USP, 2001. 
NETO, José Fortunato. Licenciamento Ambiental Municipal. São Paulo: Ministério Público de São Paulo. Disponível na Rede Mundial de Computadores no endereço: http://www.mp.sp.gov.br/caouma

NETO, Ladislau. Investigações sobre a arqueologia brasileira. Arquivos do Museu Nacional. Rio de Janeiro, 1885, vol. VI.

NIMUENDAJU, kurt. Les recherches arqueologiques au Brésil. Journal de la Societé dês Americanistes de Paris. Tomo XX, Paris, 1928.

NORRILD, Juana A. Identidad y turismo em los asentamientos galeses de la Patagonia Argentina. Anais do $2^{\circ}$ Congresso Virtual de Antropología y Arqueologia. Ciberespacio, 2000.

NUNES, Reginaldo. Patrimônio artístico e histórico nacional. Tombamento. Desapropriação. Concessão de lavra. Revista de Direito Administrativo, v. 76, abr. - jun., 1964, p.444-450.

O'KEEFE, Patrick. Archaeology and human rights. Public Archaeology, vol. 3, London: James \& James, 2000, p. 181 - 194.

OLIVEIRA, Helli Alves de. Responsabilidade pelos danos ao patrimônio cultural. Revista Forense, v. 319, jul. - set., 1992, p.49-56.

OLIVEIRA, Mário Sérgio C. de. Os Sambaquis da planície costeira de Joinville, litoral norte de Santa Catarian: Geologia, Paleografia e Conservação in situ. Florianópolis: Depto. De Geociências - CFCH/UFSC, 2000. Diss. Mestrado.

PACCAGNelLA, Luís Enrique. Dano Moral Ambiental. São Paulo: Ministério Público de São Paulo. Disponível na Rede Mundial de Computadores no endereço: http://www.mp.sp.gov.br/caouma/caouma.htm

PACIELLO, Carlos Eduardo de Castro. Da vigência do Artigo 40 da Lei dos Crimes Contra o Ambiente e da Aplicação aos Parques Estaduais e Municipais. São Paulo: Ministério Público de São Paulo. Disponível na Rede Mundial de Computadores no endereço:

http://www.mp.sp.gov.br/caouma/caouma.htm

PAIVA, Ângela. Laboratório de Estudos e Pesquisas - Laguna. Texto inédito. 
PALADOFF, J. M. Arqueologia rio-grandense. Revista do Museu Paulista. São Paulo, 1898, vol. IV.

PALLESTRINI, Luciana. Interpretação de estruturas arqueológicas em sítios do Estado de São Paulo. Série Arqueologia. São Paulo: Fundo de Pesquisas do Museu Paulista, nº1, 1975.

PASSOS, Lídia Helena Ferreira da Costa. Conjunto histórico arquitetônico do Parque da Independência, Museu do Ipiranga, Museu Paulista. Serviços indispensáveis à preservação e uso deste patrimônio. Obrigação de fazer consistente em proteger, restaurar, recuperar e manter os bens tombados. Revista de Direito Ambiental, v. 16, out. - dez., 1999, p.203-208.

PAULA JÚNIOR, Daury de. O Ministério Público e a Proteção do Patrimônio Arqueológico. São Paulo: Ministério Público de São Paulo. Disponível na Rede Mundial de Computadores no endereço: http://www.mp.sp.gov.br/caouma

PAULA, Fabiano Lopes de, BAETA, Alenice Motta. Política Patrimonial Arqueológica no Estado de Minas Gerais. O Carste. Belo Horizonte, v. 12, nº 04, out. 2000.

PEDRO, Maria de F. A. S; PEREZ, Rhoneds Aldora R. Patrimônio Arqueológico: conhecendo a legislação. Revista de Arqueologia. Rio de Janeiro: SAB, 1997, p. $51-70$.

PELLEGRINI, Luiz Fernando Gama. A proteção de que gozam os monumentos e obras de valores artístico ou histórico. Revista de Direito Civil, Imobiliário, Agrário e Empresarial, v. 23, jan. - mar., 1983, p. 86-90.

PENA, Domingos Soares Ferreira. Apontamentos sobre os Cerâmicos do Pára. Arquivos do Museu Nacional. Rio de Janeiro, 1876, vol. I.

PENHA, Denise H. de la. O papel dos museus antropológicos no Brasil. Estudos de Museologia, Caderno de Ensaios n 02, Rio de Janeiro: MinC/lphan, 1994, p. $29-40$.

PILLES Jr., Depredação de sítios arqueológicos: a resposta do Arizona. In: INSTITUTO DO PATRIMÔNIO HISTÓRICO E ARTÍSTICO NACIONAL. Métodos arqueológicos e gerenciamento de Bens Culturais. Rio de Janeiro: Departamento de Promoção, 1994, pp. 35 - 68. 
PIRES, Maria Coeli Simões. Da proteção ao patrimônio cultural. Belo Horizonte: Del Rey, 1994, p. 230.

- Direito urbanístico, meio ambiente e patrimônio cultural. Revista de Informação Legislativa, v.151, jul. - set., 2001, p.207230.

PREFEITURA MUNICIPAL DE BLUMENAU. Indígenas do Itajaí. Blumenau em Cadernos, Blumenau, 1967, Tomo VII, nº 06 e 07.

PRICE, Nicholas P. Stanley. Patrimônio natural e arqueológico. Ética na intervenção para a conservação do patrimônio arqueológico e natural. Anais do Seminário Internacional, 6 dez. 1996, p. 144.

RAPOSO, Luís.; SILVA, Antonio C. A linguagem das coisas. Ensaios e Crónicas de Arqueologia. Lisboa: Publicações Europa-América, 1994.

RATH, C. J. Frederico. Notícia etnológica sobre um povo que já habitou as costas do Brasil bem como o interior, antes do dilúvio universal. Revista do Instituto Histórico e Geográfico Brasileiro. Rio de Janeiro, 1871, vol. XXXIV.

RIBEIRO, Berta G. Museu e Memória. Reflexões sobre o Colecionamento. Ciências em Museus, 1989, p. $109-122$.

RODRIGUES, José Eduardo Ramos. A evolução da proteção do patrimônio cultural: crimes contra o ordenamento urbano e o patrimônio cultural. Temas de direito ambiental e urbanístico, ano 2, no 3, 1998, p.199-225.

. Aspectos jurídicos da proteção ao patrimônio cultural, arqueológico e paleontológico. Revista de Direito Ambiental, v. 6, abr. - jun., 1997, p.116-119.

In: MILARÉ, Edis et al.. Meio ambiente cultural: tombamento - ação civil pública e aspectos criminais. Ação Civil Pública. Revista dos Tribunais, 2001, p. 309.

. Patrimônio cultural: análise de alguns aspectos polêmicos. Revista de Direito Ambiental, v. 21, jan. - mar., 2001, p.174-191. 
. Tombamento e patrimônio cultural. Dano ambiental, prevenção, reparação e repressão. Revista de Direito Civil, Imobiliário, Agrário e Empresarial, v. 66, out. - dez., 1993, p. 52-69.

RODRIGUES, Marly. Preservar e consumir: o patrimônio histórico e o turismo. In: FUNARI, Pedro P.A.; PINSKY, Jaime (Orgs). Patrimônio Cultural e Turismo. São Paulo: Contexto, 2001, p. $15-24$.

ROOSEVELT, A. C. Determinismo ecológico na interpretação do desenvolvimento social indígena da Amazônia. In: NEVES, Walter A. Origem, adaptações e diversidade biológica do homem nativo da Amazônia. Belém: Museu Paraense Emílio Goeldi, 1991, p. 103 - 141.

ROSA, Sylvio Lopes da. Questões sobre Educação Ambiental. Série Fascículos OCTA, 16 set. São Paulo: Octa Consultoria e Planejamento, 1999.

ROY, Jean-Bernard. La documentation dans les musées archéologiques. Musées et documentation, n. 212, Paris, 1996, p. $16-21$.

SALVATORE, P.Tutela Pubblica dell'Ambiente. In: Rassegna Semestrale dell'Unione Nazionale Avvocati degli Enti Pubblici, Roma, 1975, p. 343.

SAMPAIO, Teodoro. Arqueologia brasileira. Dicionário histórico geográfico e etnográfico do Brasil. Rio de Janeiro, 1922, vol. I.

SANTANA, Agustín. Patrimônio cultural y turismo: reflexiones y dudas de un anfitrión. Anais do $1^{\circ}$ Congresso Virtual de Antropología y Arqueologia. Ciberespacio, Outubro de 1998.

SANTANA, Jair Eduardo. Competência legislativa municipal para o tombamento. Instituição pela via legislativa. Revista Forense, v. 344, out. - dez., 1998, p.479-482.

SANTOS, Antônio Silveira Ribeiro dos. Protegendo o patrimônio cultural. Revista da Associação Paulista do Ministério Público, v. 10, set., 1997, p.40-41.

SANTOS, Márcia Walquíria Batista dos. Proteção do patrimônio cultural no direito italiano. Cadernos de Direito Constitucional e Ciência Política, v. 4, jul. set., v. 4, 1993, p.158 -165. 
SANTOS, Silvio C. dos. Os índios Xokleng: memória visual. Florianópolis: Ed. da UFSC/UNIVALI, 1997.

Os Xokleng hoje. Blumenau. Cadernos. Blumenau, 1965.

SÃO PAULO. SECRETARIA MUNICIPAL DE CULTURA. O direito à memória: patrimônio histórico e cidadania. São Paulo: Departamento de Patrimônio Histórico, 1992.

SÃO PEDRO, Maria de F. A., PEREZ, Rhoneds A. R. Patrimônio Arqueológico: conhecendo a legislação. Revista de Arqueologia. Rio de Janeiro: SAB, 1997.

SARAMAGO, José. Os escritores perante o racismo. In: Schwarcz, Lilia M.; SILVA, Renato da, (orgs.). Raça e Diversidade. São Paulo: Estação Ciência: Edusp, 1996, p. $77-81$.

SCHADLA-HALL, Tim. Communicating Archaeology. Public Archaeology, vol. 1, London: James \& James, 2000, p. 211 - 213.

SHANKS, Michael, TILLEY, Christopher. Social Theory and Achaeology. Cambridge: Polity, 1987.

SHEPHERD, N. J. World Archaeology in the White South. Public Archaeology, vol. 1, n. 2, London: James \& James, 2000, p. $143-156$.

SILVA, Carlos Medeiros. Patrimônio artístico e histórico nacional. Tombamento. Desapropriação. Concessão de lavra. Ato administrativo. Revogação. Revista de Direito Administrativo, v. 67, jan. - mar., 1962, p. 248-258.

. Patrimônio histórico e artístico nacional. Tombamento. Notificação do proprietário. Registro. Nulidade. Revista de Direito Administrativo, v. 120, abr. - jun., 1975, p. 459-469.

. Patrimônio histórico e artístico nacional. Tombamento. Vizinhança. Desapropriação. Registro de imóveis. Direitos de terceiros. Revista de Direito Administrativo, v. 108, abr. - jun., 1972, p. 429 - 441.

SILVA, Eliane Azevedo e. Manual do morador de Olinda: Conservação das Edificações particulares do sítio histórico de Olinda. Olinda: Fundação Centro de Preservação de Sítios Históricos de Olinda, 1992. 
SILVA, José Afonso da. Direito Urbanístico Brasileiro. $2^{\circ}$ ed. São Paulo: Malheiros, 1995.

SILVA, Maria Coeli Pinheiro da. Compatibilizando os instrumentos legais de preservação arqueológica no Brasil: o decreto-lei no 25/37 e a lei 3.924/61. Revista de Arqueologia. SAB, v. 9, 1996.

SILVA, Maria Regina B e. As pesquisas em Arqueologia e Etnologia e as Exposições. Ciências em Museus, n. 04, 1992, p. 63 - 65.

SIMON, Lílian Mendonça. Laguna: Patrimônio e Desenvolvimento. Texto inédito.

SODRÉ, Nelson Werneck. Síntese da História da Cultura Brasileira. Rio de Janeiro: Ed. Civilização Brasileira, 1972.

SOMMER, Ulrike. Archaeology and Regional Identity in Saxony. Public Archaeology, vol. 1, London: James \& James, 2000, p. 125 - 142.

SOUTO, Luís Eduardo Couto de Oliveira. Competência do município no exercício do poder de polícia em áreas da União. São Paulo: Ministério Público de São Paulo, 2004. Disponível na Rede Mundial de Computadores no endereço: http://www.mp.sp.gov.br/caouma

SOUZA, Alcídio Mafra. Laguna. In: Guia dos bens tombados - Santa Catarina. Rio de Janeiro: Ed. Expressão e Cultura, 1992.

SOUZA, Sueide Couto Neco de. Aspectos históricos e tratamento constitucional do tombamento. Revista Jurídica da Universidade de Franca, v. 7, jul. - dez., 2001, p.221-230.

TAMANINI, Elizabete. Museu Arqueológico de Sambaqui: um olhar necessário. Campinas: Unicamp, 1994. Diss. Mestrado.

. O museu, a arqueologia e o público: um olhar necessário. In: FUNARI, Pedro P. A. Cultura Material e Arqueologia Histórica. Campinas: UNICAMP/Instituto de Filosofia e Ciências Humanas, 1998, p. 179 - 220.

TELLES, Augusto Carlos da S. Os monumentos e os sítios face a vida contemporânea. A experiência brasileira. Texto não publicado.

TELLES, Norma de Abreu. Cartografia brasilis ou: esta história está mal contada. São Paulo: Ed. Loyola, 1984. 
TERNES, Apolinário. História Econômica de Joinville. Joinveille: Meyer, 1986.

TIBURTIUS G. et alli. Sobre a ocorrência de bula timpânica de baleia e artefatos derivados nos sambaquis dos estados do Paraná e Santa Catarina. Arquivos de Biologia e Tecnologia. Curitiba, n. 4, 1949, p. 87 - 94.

. Nota prévia sobre a jazida paleoetnográfica de Itacoara (Joinville, Estado de Santa Catarina). Arquivos de Biologia e Tecnologia. Curitiba, n. 56, 1951, p. 315-346.

. Nota sobre a ocorrência de virotes nos estados de Paraná e Santa Catarina. Arquivos de Biologia e Tecnologia. Curitiba, n. 9, 1954, p. 87-88. ; BIGARELLA, J. J. Objetos zoomorfos do litoral de Santa Catarina. Pesquisas; Antropologia. Porto Alegre, n. 07, 1960.

; LEPREVOST, A. Nota sobre a ocorrência de machados de pedra nos estados do Paraná e Santa Catarina. Arquivos de Biologia e Tecnologia. Curitiba, n. 8, 1953, p. 503-554.

TOCCHETTO, Fernanda B. Arqueologia da cidade: reflexões e propostas para Porto Alegre. Congresso da Sociedade de Arqueologia Brasileira, 02, Rio de Janeiro, 1997.

TUGLIO, Vânia Maria. Patrimônio Histórico: uma lacuna legal? São Paulo: Ministério Público de São Paulo. Disponível na Rede Mundial de Computadores no endereço: http://www.mp.sp.gov.br/caouma/caouma.htm

URBANCZYK, Przemyslaw. Political circumstances reflected in post-war Polish archaeology. Public Archaeology, vol. 1, n. 01, London: James \& James, 2000 , p. $49-56$.

VASCONCELOS, Camilo de Mello. A Pré-História Brasileira no Livro Didático de $1^{\circ}$ Grau. TENÓRIO, Maria C.; FRANCO, Teresa C. (orgs.) Seminário para a implantação da temática pré-histórica brasileira no ensino de $1^{\circ}, 2^{\circ}$ e $3^{\circ}$ Graus. Rio de Janeiro: UFRJ/MN, 1994, p. $09-20$.

WIENER, Carlos. Estudo sobre os sambaquis do Sul do Brasil. Arquivos do Museu Nacional. Rio de Janeiro, 1876, vol. I. 
ZAMORA, Oscar M. F. A arqueologia como história. Dédalo. São Paulo, $\mathrm{n}^{\circ} 28, \mathrm{pp}$. $39-62,1990$.

\section{Sites Consultados:}

http://www.stf.gov.br

http://www.stj.gov.br

http://www.trf1.gov.br

http://www.tjmg.gov.br

http://www.tjsp.gov.br

http://www.tjsc.gov.br

http://www.tjs.gov.br

http://www.tjpr.gov.br

http://www.tjes.gov.br

http://www.mp.sp.gov.br

http://www.mp.sc.gov.br

http://www.mp.mg.gov.br

http://www.mp.rs.gov.br

http://www.mp.pr.gov.br

http://www.mp.es.gov.br

http://www.mp.ms.gov.br

http://www.mp.mt.gov.br

http://www.mp.ba.gov.br

http://www.mp.pe.gov.br

http://www.mp.se.gov.br

http://www.mp.pa.gov.br

http://www.mp.am.gov.br 
http://www.leismunicipais.com.br

http://www.arqueologia.ilha.sites.uol.com.br

http://www.iphan.gov.br

http://www.florianopolis.sc.gov.br

http://www.belem.pa.gov.br

http://www.soleis.adv.br 